\title{
INVOLVEMENT OF FOXO TRANSCRIPTION FACTORS AND \\ GLYCOGEN SYNTHASE KINASE 3 IN THE FREEZE \\ TOLERANCE CAPABILITY OF THE WOOD FROG, \\ RANA SYLVATICA
}

Melanie C. Bouffard

B.Sc. Carleton University, 2005

A Thesis Submitted to the Faculty of Graduate Studies and Research in partial fulfillment of the requirements for the degree of

Masters of Science

Department of Chemistry

Carleton University

Ottawa, Ontario, Canada

(C) Copyright 2007

Melanie Christianne Bouffard 


$\begin{array}{ll}\begin{array}{l}\text { Library and } \\ \text { Archives Canada }\end{array} & \begin{array}{l}\text { Bibliothèque et } \\ \text { Archives Canada }\end{array} \\ \begin{array}{l}\text { Published Heritage } \\ \text { Branch }\end{array} & \begin{array}{l}\text { Direction du } \\ \text { Patrimoine de l'édition }\end{array} \\ \begin{array}{l}\text { 395 Wellington Street } \\ \text { Ottawa ON K1A ON4 }\end{array} & \begin{array}{l}\text { 395, rue Wellington } \\ \text { Ottawa ON K1A ON4 } \\ \text { Canada }\end{array}\end{array}$

Your file Votre référence ISBN: 978-0-494-33691-5 Our file Notre référence ISBN: 978-0-494-33691-5

NOTICE:

The author has granted a nonexclusive license allowing Library and Archives Canada to reproduce, publish, archive, preserve, conserve, communicate to the public by telecommunication or on the Internet, loan, distribute and sell theses worldwide, for commercial or noncommercial purposes, in microform, paper, electronic and/or any other formats.

The author retains copyright ownership and moral rights in this thesis. Neither the thesis nor substantial extracts from it may be printed or otherwise reproduced without the author's permission.
AVIS:

L'auteur a accordé une licence non exclusive permettant à la Bibliothèque et Archives Canada de reproduire, publier, archiver, sauvegarder, conserver, transmettre au public par télécommunication ou par l'Internet, prêter, distribuer et vendre des thèses partout dans le monde, à des fins commerciales ou autres, sur support microforme, papier, électronique et/ou autres formats.

L'auteur conserve la propriété du droit d'auteur et des droits moraux qui protège cette thèse. $\mathrm{Ni}$ la thèse ni des extraits substantiels de celle-ci ne doivent être imprimés ou autrement reproduits sans son autorisation.
In compliance with the Canadian

Privacy Act some supporting forms may have been removed from this thesis.

While these forms may be included in the document page count, their removal does not represent any loss of content from the thesis.
Conformément à la loi canadienne sur la protection de la vie privée, quelques formulaires secondaires ont été enlevés de cette thèse.

Bien que ces formulaires aient inclus dans la pagination, il n'y aura aucun contenu manquant.

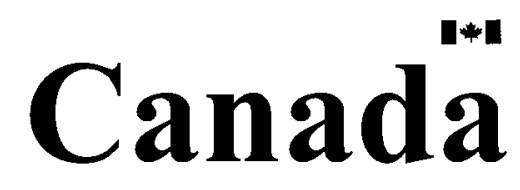




\begin{abstract}
Animals cope with the subzero temperatures of winter in different ways. The wood frog, Rana sylvatica, endures whole body freezing and is able to survive weeks completely frozen. Organisms that endure extreme environmental stress on a periodic or seasonal basis have developed ways to strongly suppress their metabolic rate and enter a hypometabolic state to survive. Forkhead box 'other' (FOXO) transcription factors have important roles in various cellular processes such as metabolism, cellular proliferation, stress tolerance and lifespan. Immunoblotting was used to assess total and phosphorylated amounts of FOXO proteins in wood frog organs. Active FOXO1 increased in brain during freezing and thawing, possibly due to a need for gluconeogenesis during this stress. The levels of active FOXO3 increased in frog brain, kidney and liver during freezing and thawing and also during anoxia and aerobic recovery after anoxia, which could be due to the need to maintain or enhance antioxidant defenses under these stresses. Glycogen synthase kinase-3 (GSK3) is a protein kinase known to inhibit glycogen synthesis, cell growth and differentiation and protein translation. The amount of active GSK3 increased in the frozen state in brain, heart, kidney, liver and muscle of wood frogs. Furthermore, kinetic analysis of GSK3 showed that the skeletal muscle of frozen frogs appears to have a higher affinity for its substrate when compared to control GSK3. Allosteric effectors of GSK3 were also identified: glucose-6-phosphate activated the enzyme whereas AMP inhibited. The data expand our understanding of metabolic regulation during natural freeze tolerance.
\end{abstract}




\section{Acknowledgements}

First and foremost, I would like to thank my thesis supervisor, Dr. Kenneth Storey, for giving me the opportunity to do this research and also for his help and encouragement along the way. I would also sincerely like to thank Janet Storey for editing help with my thesis and also for sharing her vast knowledge of this research. I would also like to thank the Storey lab members for teaching me and helping me along the way.

I would also like to thank my parents, Kenneth and Lise-Anne Boal, and my brothers and sisters (Emilie, Justin, Mireille, Emma, Luke and Steven) for all their encouragement throughout all of my post-secondary studies. 
Title page

Acceptance sheet $\quad$ ii

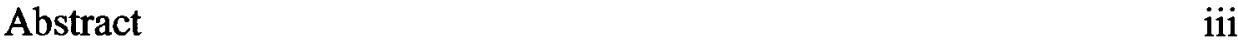

Acknowledgments $\quad$ iv

Table of Contents $\quad \mathrm{v}$

List of Abbreviations $\quad$ vi

List of Figures vii

List of Tables viii

Chapter 1: General Introduction 1

Chapter 2: Involvement of FOXO Transcription Factors $\begin{array}{ll}\text { during Freezing and Anoxia } & 13\end{array}$

Chapter 3: Regulation of Glycogen Synthase Kinase 42

Chapter 4: General Discussion $\quad 76$

$\begin{array}{ll}\text { References } & 88\end{array}$ 


\section{List of Abbreviations}

\begin{tabular}{|c|c|}
\hline Akt & Protein kinase B \\
\hline AMP & Adenosine monophosphate \\
\hline ATP & Adenosine triphosphate \\
\hline cAMP & Cyclic 3',5'-adenosine monophosphate \\
\hline CK1 & Casein Kinase 1 \\
\hline DNA & Deoxyribonucleic acid \\
\hline DYRK1A & Dual-specificity regulated kinase $1 \mathrm{~A}$ \\
\hline ECL & Enhanced chemiluminescence \\
\hline EDTA & Ethylenediamine tetra-acetic acid \\
\hline EGTA & Ethyleneglycol bis( $\beta$-aminoethyl ether) tetra-acetic acid \\
\hline eIF-2B & Eukaryotic initiation factor $2 \mathrm{~B}$ \\
\hline FOXO & Forkhead box 'other' \\
\hline GADD & Growth arrest and DNA damage \\
\hline GP & Glycogen phosphatase \\
\hline G6P & Glucose-6-phosphate \\
\hline G6Pase & Glucose-6-phosphatase \\
\hline GS & Glycogen synthase \\
\hline GSK3 & Glycogen synthase kinase 3 \\
\hline IGFBP-1 & Insulin-like growth factor binding protein 1 \\
\hline IRS & Insulin receptor substrate \\
\hline $\mathrm{kDa}$ & Kilodalton \\
\hline $\mathrm{K}_{\mathrm{m}}$ & Michaelis-Menten constant \\
\hline MAPK & Mitogen-activated protein kinase \\
\hline MnSOD & Manganese superoxide dismutase \\
\hline mRNA & messenger RNA \\
\hline PAGE & Polyacrylamide gel electrophoresis \\
\hline PEP & Phosphoenolpyruvate \\
\hline PI3K & Phosphoinositide- 3 kinase \\
\hline PDK1 & Phosphoinositide-dependent protein kinase \\
\hline PDK4 & Pyruvate dehydrogenase kinase 4 \\
\hline PEPCK & Phosphoenolpyruvate carboxykinase \\
\hline PKB & Protein kinase $\mathrm{B}$ \\
\hline PKC & Protein kinase $\mathrm{C}$ \\
\hline PMSF & Phenylmethysulfonyl fluoride \\
\hline PVDF & Polyvinylidene difluoride \\
\hline RNA & Ribonucleic acid \\
\hline SDS & Sodium dodecyl sulfate \\
\hline SGK & Serum and glucocorticoid-regulated kinase \\
\hline TBST & Tris-buffered saline Tween- 20 \\
\hline Tris & Tris(hydroxymethyl)aminomethane \\
\hline $\mathrm{V}_{\max }$ & Maximum reaction velocity \\
\hline
\end{tabular}


1.1 Range distribution of the wood frog.

$2.1 \quad \mathrm{PKB} / \mathrm{Akt}$ signal transduction pathway regulating FOXO transcription factors.

2.2 Western blot analysis of FOXO1 protein content in brain, kidney and liver of wood frogs from three conditions (control, frozen, thawed)

2.3 Western blot analysis of phospho-FOXO1 (ser 256) protein content in brain, kidney and liver of wood frogs from three conditions

2.4 Western blot analysis of $\mathrm{FOXO} 3$ protein content in brain, heart, kidney and liver of wood frogs from three conditions (control, frozen, thawed)

2.5 Western blot analysis of phospho-FOXO3 (ser 253) protein content in brain, heart, kidney and liver of wood frogs from three conditions

2.6 Western blot analysis of phospho-FOXO3 (ser 318/321) protein content in brain, heart, kidney and liver of wood frogs from three conditions

2.7 Western blot analysis of FOXO3 protein content in brain, heart, kidney and liver of wood frogs from three conditions

2.8 Western blot analysis of phospho-FOXO3 (ser318/321) protein content in brain, heart, kidney and liver of wood frogs from three conditions

3.1 Western blot analysis of GSK3 protein content in brain, heart, kidney, liver and muscle of wood frogs from three conditions

3.2 Western blot analysis of phospho-GSK3 (ser 9) protein content in brain, heart, kidney, liver and muscle of wood frogs from three conditions

3.3 Velocity of GSK3 in Rana sylvatica muscle with increasing peptide concentration at $22^{\circ} \mathrm{C}$

3.4 Velocity of GSK3 (in units/mg) in Rana sylvatica muscle with increasing peptide concentration at $4^{\circ} \mathrm{C}$

3.5 Velocity of GSK3 in Rana sylvatica muscle with increasing peptide concentration at $22^{\circ} \mathrm{C}$ with $250 \mathrm{mM}$ glucose

3.6 Velocity of GSK3 in Rana sylvatica muscle with increasing peptide concentration at $4^{\circ} \mathrm{C}$ with $250 \mathrm{mM}$ glucose

3.7 Activity of GSK3 with various metabolites performed at $22^{\circ} \mathrm{C} \quad 73$

3.8 Activity of GSK3 with various metabolites performed at $4^{\circ} \mathrm{C} \quad 74$

3.9 General schematic showing the regulation of glycogen synthesis $\begin{array}{ll}\text { and breakdown } & 75\end{array}$

4.2 The insulin pathway: phosphorylation of FOXO factors and GSK3 by Akt 
3.1 Summary of kinetic data for GSK3 for four different assay conditions: at high $\left(22^{\circ} \mathrm{C}\right)$ and low $\left(4^{\circ} \mathrm{C}\right)$ temperatures and in the absence versus presence of $250 \mathrm{mM}$ glucose at each temperature 


\section{CHAPTER 1:}

\section{General Introduction}




\section{Adaptations to Cold}

During the winter months, when temperatures fall to below $0^{\circ} \mathrm{C}$, ectothermic animals cope with the cold in different ways. Some animals are able to keep their body temperatures above $0^{\circ} \mathrm{C}$, and they do this by migrating to a warmer climate or wintering in sheltered environments either under water or underground below the frost line. Others allow their body temperature to drop below $0^{\circ} \mathrm{C}$ and deal with the potential for freezing using one of two strategies: freeze avoidance or freeze tolerance. Freeze avoidance involves the deep supercooling of body fluids and is achieved with the use of multiple kinds of antifreezes. Freeze tolerance is the controlled freezing of body water in extracellular fluid spaces while preserving the liquid state of the cytoplasm (Storey and Storey, 2004).

\section{The Wood Frog}

The wood frog, Rana sylvatica, is a freeze-tolerant vertebrate commonly found in North America (Figure 1.1) (Behler and King, 1979). This species is the primary model animal that has been used for studies of vertebrate freeze tolerance and is able to survive for weeks completely frozen. They spend the winter months near the soil surface, covered with layers of leaf litter and snow. Although these layers do provide insulation and protection from the low ambient air temperatures above the snowpack, the temperature of the soil surface during the winter months can fall as low as $-6^{\circ} \mathrm{C}$.

\section{Vertebrate Freeze Tolerance}

Many factors contribute to the injury and mortality that is associated with tissue 
freezing in most organism (including man), and freeze tolerant animals have to find ways to overcome all of these factors to survive freezing. One of these factors is the formation of ice in restricted extracellular spaces. For example, ice expansion in small capillaries of organs can rupture vessel walls so that when the ice thaws, the integrity of the vascular system is lost causing extensive internal bleeding. Indeed, this has been one of the critical limitations in developing methods for human organ cryopreservation (Rubinsky et al., 1987). Furthermore, the withdrawal of pure water into extracellular ice crystals increases the osmotic concentration of the remaining extracellular fluid and sets up a powerful osmotic gradient which sucks water out of cells, causing extensive dehydration and cell volume shrinkage. The wood frog deals with these problems in multiple ways so that ultimately $65-70 \%$ of total body water can freeze out as extracellular ice. One mechanism is to promote ice formation in extra-organ spaces such as the abdominal cavity where large masses of ice can accumulate but do little physical harm to organs. Plasma clotting factors, such as fibrinogen, are also up-regulated when frogs freeze so that when the animals subsequently thaw, any bleeding injuries can be dealt with quickly (Storey and Storey, 2004a). When freezing begins, frogs also synthesize and distribute huge amounts of glucose, a low molecular-weight cryoprotectant, to all tissues. Glucose can reach concentrations of 150-300 mM (compared with 1-5 mM normally) (Storey and Storey, 1984). Cryoprotectants are used to prevent cells from shrinking below a critical minimum cell volume since extreme shrinkage causes irreversible damage to cell membranes.. Freeze tolerant animals also manage the freezing process by initiating freezing close to the equilibrium freezing point (about $-0.5^{\circ} \mathrm{C}$ for wood frogs) so that the rate of ice formation is slow and there is plenty of time to initiate metabolic adaptations and cell 
volume adjustments. In freeze tolerant species, freezing is usually triggered in one of two ways: (a) by contact with environmental ice which seeds freezing across the skin or (b) by the action of endogenous nucleators, which can be specific ice-nucleating proteins that are synthesized and added to the blood of the organism, or bacteria (in the skin or gut) with ice-nucleating capabilities (Duman, 2001; Storey and Storey, 2004b). Wood frogs in a damp environment are typically seeded when their body temperature falls below the freezing point of their blood (about $-0.5^{\circ} \mathrm{C}$ ) whereas in a dry environment, bacteria trigger nucleation at -2 to $-3^{\circ} \mathrm{C}$. Wood frogs have blood proteins with ice nucleating abilities but it seems that these may act more guiding ice formation that in actually triggering it (Storey and Storey, 2004).

When wood frogs are nucleated at $-2^{\circ} \mathrm{C}$, the crystallization, an exothermic reaction, causes an increase in body temperature to just below the freezing point. The body temperature then holds at this value for several hours while ice slowly forms (generally the rates is $<5 \%$ of total body water per hour) and then the body temperature gradually drops back down to the ambient temperature (Layne and Lee, 1987). Because the rate of freezing is so slow, frogs may only show a slight stiffness in some parts of their skin and limbs for the first hour or more and the maximal ice content may not be reached for 12-24 hours. Freezing in wood frogs begins at some peripheral point on the skin and ice propagates inwards asymmetrically through the body (Rubinsky et al., 1994). Freezing stops blood circulation and so tissues are deprived of oxygen and bloodborne nutrients for the duration of the freeze and are also deprived of the way to dispose of accumulating waste products. This condition is called ischemia. Freeze-tolerant animals also show well-developed ischemia/anoxia resistance, which includes pathways 
of fermentative ATP generation, regulated metabolic rate depression and antioxidant defenses (to provide protection against damage caused by the reperfusion with oxygen during thawing). Freezing also terminates all vital signs, including heart beat, breathing, muscle movement, and nerve transmission (Storey and Storey, 2004). All are gradually reactivated during/after thawing (heart beat being the first to be reactivated) but the molecular mechanisms underlying the reactivations are still unknown.

\section{Metabolic Rate Depression}

Organisms that have to endure extreme environmental stress on a periodic or seasonal basis have developed ways to strongly suppress their metabolic rate and enter a hypometabolic state (e.g. dormancy, torpor) in order to survive. When organisms encounter environmental extremes that threaten normal life, limit food availability or impose severe challenges to their physiology, they need to use this conservation strategy which allows them to remain alive until conditions are more favourable for active life (Storey and Storey, 2005).

Metabolic rate depression has three main principles: (a) both intrinsic and extrinsic mechanisms are involved, (b) the rates of energy-producing and energyconsuming cellular processes are suppressed in a coordinated manner so that a new lower net rate of ATP turnover can be sustained over the long term, and (c) cellular priorities are reorganized to give preference to key functions (e.g. maintenance of membrane potential differences) and more strongly suppress or halt functions that are less essential under energy-restricted conditions (e.g. protein synthesis) (Storey and Storey, 1990; Storey and Storey, 2004b). Extrinsic influences affect metabolic rate depression in 
several ways, including a suppression of physiological functions (heart rate, breathing, digestion, muscle movement) in the hypometabolic state and a reduced cytosolic $\mathrm{pH}$ which usually accompanies entry into hypometabolism (often caused by $\mathrm{CO}_{2}$ retention to acidify blood). Intrinsic mechanisms of metabolic rate depression account for at least half of the total metabolic rate depression. They involve biochemical adjustments that coordinate the suppression of many cellular processes and pathways and reorganize the priorities for ATP use.

\section{Reversible Phosphorylation}

The most important molecular mechanism of metabolic rate depression that has been identified to date is reversible protein phosphorylation involving the covalent addition or removal of phosphate groups to enzymes and functional proteins. This is carried out by ATP-dependent protein kinases (that add phosphate groups) or protein phosphatases (that cleave phosphate groups) (MacDonald and Storey, 2002). There are many advantages of reversible protein phosphorylation as a regulatory mechanism. Reversible protein phosphorylation can change the activity state of enzymes and functional proteins, sometimes resulting in fully on-off control, can trigger the association or dissociation of regulatory subunits or proteins, and can alter the microcompartmentation of proteins within cells (Storey, 1993). Thousands of proteins are susceptible to reversible protein phosphorylation, which makes this mechanism an excellent way of coordinating the responses by many cell functions.

Another benefit of reversible protein phosphorylation is that signal transduction cascades involving protein kinases and protein phosphatases are fast and allow rapid 
inhibition of multiple ATP-utilizing functions and an equally fast reversal to re-establish normal cell functions during arousal from the hypometabolic state. Major changes in the activity states of enzymes and pathways are achieved without the need to change the overall amounts of proteins by synthesis or degradation, which is another factor that benefits fast recovery from the hypometabolic state (Storey and Storey, 2005).

\section{Anoxia/Ischemia}

When blood plasma freezes, the delivery of oxygen and nutrients to organs, the removal of wastes, and the inter-organ communication via hormones and other signals are all interrupted. Every cell is left in isolation to survive throughout the freeze using only its own internal reserves. The subzero body temperature of a frozen organism means that the metabolic rate will be very low, but because freezing may be prolonged for many weeks, each cell has to have enough fermentative fuel reserves and the ability to support basal metabolic needs over the long term using only the ATP generated from anaerobic pathways. Freeze-tolerant wood frogs show a good capacity to endure long term oxygen deprivation. Wood frogs can survive several weeks on continuous freezing (Layne et al., 1998) and easily endure 2 days of exposure to a nitrogen gas atmosphere at $5^{\circ} \mathrm{C}$ (Holden and Storey, 1997). Over the course of a freezing event, wood frog organs show the expected vertebrate response to oxygen limitation which is a depletion of ATP and an accumulation of glycolytic end products (lactate and alanine) (Storey, 1987). These parameters are normalized 3-11 days post-thaw.

All organisms have to deal with a constant assault to cellular metabolism by reactive oxygen species such as superoxide, hydrogen peroxide, hydroxyl radicals and 
peroxynitrite. These highly reactive species cause serious damage to cellular lipids, proteins and DNA. Because of this all organisms have antioxidant defenses consisting both of enzymes and of metabolites (e.g. glutathione, ascorbate, thioredoxin) that prevent, minimize or repair damage by reactive oxygen species. Oxidative damage is an inescapable part of an aerobic lifestyle but is also enhanced under many environmental stress conditions and in various disorders including three that are of direct relevance to vertebrate freeze tolerance - ischaemic heart disease, stroke and diabetes (Ahmad, 1995). It is now known that metabolic damage caused by ischemia arises both from oxygen deprivation during the period of restricted/halted blood flow and from the rapid reintroduction of oxygen during the reperfusion phase. Reoxygenation results in a burst of oxyradical production that can temporarily overwhelm the cell's antioxidant defenses and cause extensive damage to cellular macromolecules (Benson and Bremner, 2004).

Natural freeze-thaw by freeze tolerant organisms is an ischaemia-reperfusion event that has the potential to cause oxidative damage to organs when tissue oxygenation is restored during thawing. In the case of freeze-tolerant frogs that use glucose as a cryoprotectant, reactive oxygen species can also be enhanced by high glucose and glucose-mediated oxidative damage is another type of oxidative stress that must be dealt with (Woods and Storey, 2006). Reactive oxygen species are well known to play a role in tissue damage in human diabetes (Kristal and $\mathrm{Yu}, 1992)$ and several modes of glucoserelated oxidative damage are known. For example, free glucose is prone to autooxidation in the presence of transition metals (iron, copper) to form protein-reactive dicarbonyl compounds and hydrogen peroxide (leading to hydroxyl radical formation) (Wolff et al., 1991). 
Studies with wood frogs indicate that at least two different strategies exist which contribute to the defense against oxidative stress associated with freeze-thaw. The first is the maintenance of constantly high activities of antioxidant enzymes in frog organs. Activities of six antioxidant enzymes (superoxide dismutase, catalase, glutathione Stransferase, glutathione reductase, and total and Se-dependent glutathione peroxidases) were assessed in wood frogs versus leopard frogs and they were found to be uniformly higher in the liver of freeze tolerant wood frogs as compared with freeze intolerant leopard frogs (Joanisse and Storey, 1996). The high antioxidant defenses of the wood frog correlates with the absence of oxidative damage to cellular lipids over a course of freeze-thaw (Joanisse and Storey, 1996). The second strategy for antioxidant defense in wood frogs is selective changes to the activities of the antioxidant enzymes in different tissues in response to freezing. For example, total glutathione peroxidase activity increased significantly (by $20-150 \%$ ) in all five organs tested (brain, heart, kidney, liver, muscle) and selenium-dependent glutathione peroxidase activity rose by $\sim 2$-fold in heart, kidney and skeletal muscle (Joanisse and Storey, 1996). In most cases, activities returned to near control values after $24 \mathrm{~h}$ thawing, which suggests that the need for enhanced defenses against peroxidative damage is greatest during freezing or immediately after thawing, a time when glucose is also very high. Selective changes to the activities of these enzymes could minimize the potential for glucose-mediated oxidative damage to macromolecules, a significant problem associated with sustained high glucose levels in human diabetes (Wolff et al., 1991). 


\section{Hypothesis and Experimental Outline}

Hypothesis: Freezing survival by wood frogs involves the up-regulation and activation of proteins involved in antioxidant defense and metabolic rate depression.

\section{Experimental Outline}

To test this hypothesis, two types of studies were undertaken. In Chapter 2 Western blotting was used to analyze organ-specific changes in the levels of Forkhead box other (FOXO) proteins during freeze/thaw and anoxia/recovery in wood frogs. FOXO proteins are important transcription factors that regulate the expression of multiple genes involved in cell proliferation, protection from oxidative stress and regulation of metabolism. By understanding how this family of transcription factors responds to freezing and anoxia stresses we gain valuable insights into the regulation and responses of genes under their control. In Chapter 3, enzymatic studies of an important cellular protein kinase, glycogen synthase kinase 3 (GSK3), are presented. GSK3 was first discovered as an important regulator of carbohydrate metabolism in animal cells helping to mediate glycogen storage versus glucose release. It is now known that substrates phosphorylated by GSK3 have roles in a wide spectrum of cellular processes that are influenced by fuel availability, including glycogen metabolism, gene transcription, protein translation, cytoskeletal regulation, intracellular vesicular transport, cell cycle progression and apoptosis. Studies of wood frog muscle GSK3 from control versus frozen animals were conducted using a radioactive assay and reveal important information about the activity, regulation, and actions of this kinase in an animal with a highly unusually carbohydrate (glucose) metabolism. 
Figure 1.1 : Range distribution of the wood frog. From: Northern Prairie Wildlife Research Center (http://www.npwrc.usgs.gov/resource/herps/amphibid/species/wood1.htm) 


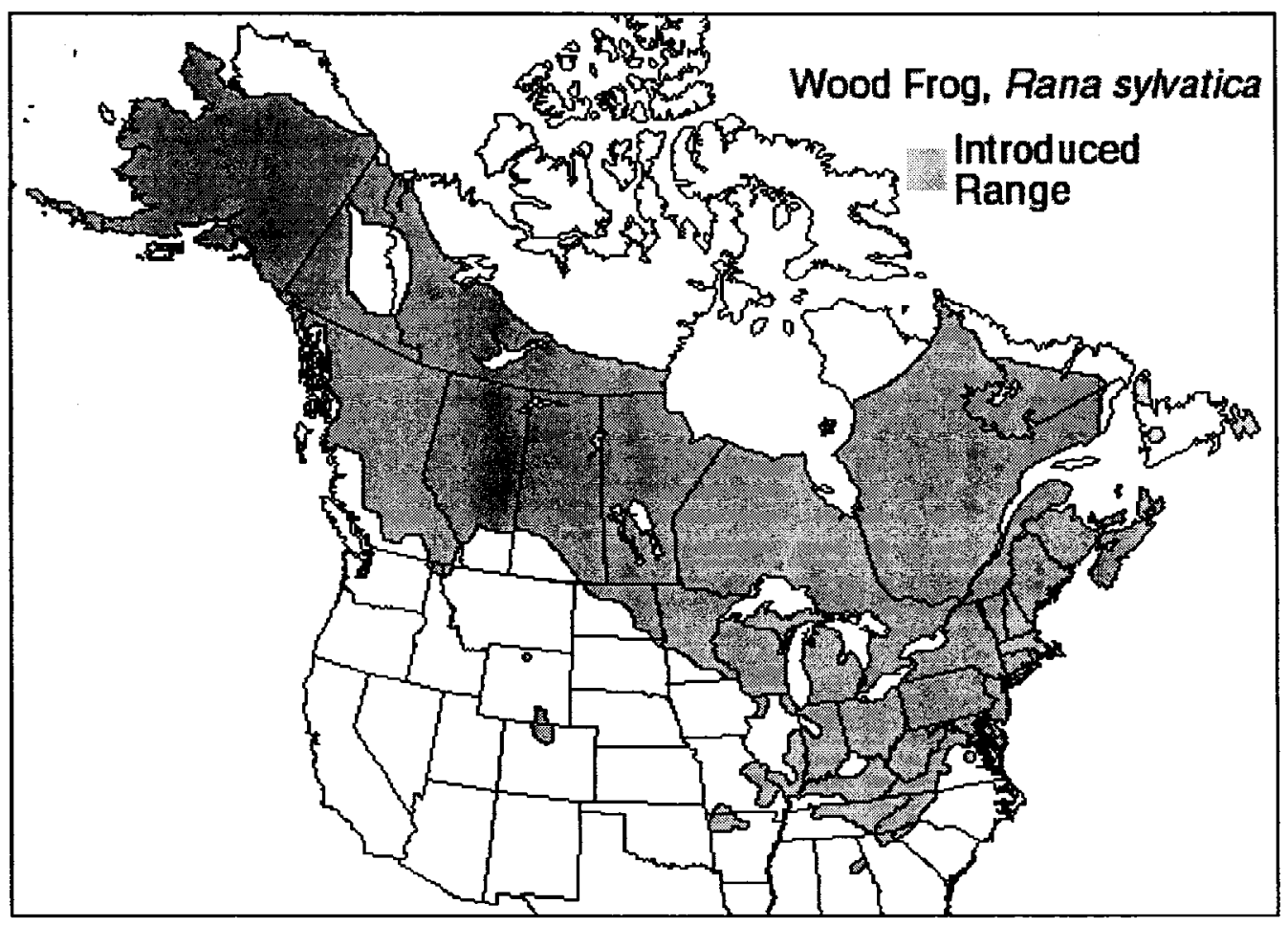




\section{CHAPTER 2:}

\section{Involvement of FOXO Transcription Factors during Freezing and Anoxia}




\section{Introduction}

\section{Forkhead Box Transcription Factors}

The Forkhead family of transcription factors comprises more than 100 different members that have been shown to play important roles in cell proliferation, differentiation, tissue-specific gene expression and embryogenesis (Carlsson and Mahlapuu, 2002). Forkhead transcription factors are characterized by the presence of a highly conserved, monomeric DNA-binding domain, which is also known as the Forkhead box (Weigel and Jackle, 1990). The Forkhead box is made up of 110 amino acids that form a butterfly-shaped structure made up of three tightly packed $\mathrm{N}$-terminal $\alpha$ helices, three $\beta$-sheets, and two loop regions located at the C-terminal end that shape the wings of the structure (Clark et al., 1993). The Forkhead box is sometimes referred to as the winged-helix motif as a result of its structural characteristics.

DNA binding of Forkhead proteins relies on interactions between the third helix of the Forkhead box (called H3) and DNA bases within the major groove of doublestranded DNA. The residues present in the two loops make additional contacts with the DNA-binding element which contribute to binding-site selectivity of the different Forkhead proteins (Clark et al., 1993). A core recognition motif of 7 base pairs has been identified (T-(G/A)-T-T-(G/T)-(G/A)-(C/T)) which is necessary for Forkhead binding, whereas bases immediately flanking the core contribute to binding specificity of the different family members (Pierrou et al., 1994).

\section{Forkhead Box “Other" (Foxo) transcription Factors}

Forkhead proteins have been assigned to 17 subfamilies ranging from FOXA to 
FOXQ (Kaestner et al., 2000). Of the 17 subfamilies, FOXO (also known as Forkhead Box "Other" protein) factors are the only ones known to date to be regulated by the $\mathrm{PKB} / \mathrm{Akt}$ signal transduction pathway (Figure 2.1). They contain a unique insert of five amino acids within the region of the DNA binding domain ( $\alpha$-helix 3 ) that is directly involved in the sequence-specific interaction with DNA binding sites (Barthel et al., 2005). The consensus binding sequence for FOXO proteins (TTGTTTAC) diverges from that of other Forkhead proteins, which provides a mechanism by which FOXO proteins can preferentially interact with a distinct set of target sites in the genome. Three FOXO proteins (FOXO1, FOXO3, FOXO4) are known to be phosphorylated at three highly conserved predicted PKB phosphorylation sites (corresponding to Thr24, Ser 256 and Ser 319 in human FOXO1) not found in other Forkhead transcription factors.

Phosphorylation of these sites by PKB and/or related kinases results in inactivation and nuclear exclusion of FOXO proteins through multiple mechanisms (Biggs et al., 1999). Inhibition of the $\mathrm{PKB} / \mathrm{Akt}$ pathway causes FOXO to localize almost exclusively to the nucleus, and activation of $\mathrm{PKB} / \mathrm{Akt}$ results in the retention of FOXO in the cytoplasm and a consequent inhibition of FOXO-mediated transcription (Brownawell et al., 2001).

Even though FOXO proteins are mainly regulated by the Akt/PKB pathway, they are also "fine-tuned" and phosphorylated by other protein kinases such as Casein Kinase 1 (CK1) and the dual-specificity regulated kinase 1A (DYRK1A) (Figure 2.1 B). These kinases regulate the intracellular localization and function of FOXO proteins by phosphorylating FOXO factors within several different intramolecular domains (Van der Heide et al., 2004).

FOXO sequences are highly similar, but there are significant variations between 
members. Consequently, some genes display response elements that will bind multiple FOXO proteins, but other genes show selective sensitivity to one or another member (Czech, 2003). FOXO transcription factors are involved in regulation of cell proliferation, protection from oxidative stress and regulation of metabolism. Overexpression of FOXO factors in a large variety of mammalian cell types causes a strong inhibition of cell proliferation. FOXO factors can oppose the growth-stimulating effects of PKB/Akt when expressed at sufficiently high levels (Kops et al., 2002a). FOXO members increase the expression of the cyclin-dependent kinase inhibitor $\mathrm{p} 27^{\mathrm{kip1}}$, a protein that is linked to a cell-cycle arrest in $\mathrm{G}_{0} / \mathrm{G}_{1}$ (Nakamura et al., 2000). FOXO proteins also induce cell-cycle arrest through repression of D-type cyclins which are required for cell-cycle progression in G1 (Schmidt et al., 2002). FOXO transcription factors are also involved in protection from oxidative stress. The expression of manganese superoxide dismutase (MnSOD) and catalase were shown to be regulated by FOXO3 during oxidative stress (Kops et al., 2002b; Nemoto and Finkel, 2002). FOXOs also control the expression of a protein called growth arrest and DNA damage (GADD)45, which is involved in DNA repair (Tran et al., 2002). FOXO proteins also stimulate the expression of pyruvate dehydrogenase kinase-4, which limits oxidative metabolism of glucose and conserves glucose for utilization in other tissues (Furuyama et al., 2003). FOXO1 also binds to the insulin-like growth factor binding protein-1 (IGFBP-1) which binds to insulin growth factors and inhibits their activities (Durham et al., 1999).

Since FOXO proteins are involved in cell-cycle arrest, DNA damage control and oxidative stress protection, I hypothesized that these transcription factors will be more active under freezing and anoxia stresses in the wood frog, Rana sylvatica. 


\section{Materials and Methods}

\section{Animal experiments}

Male wood frogs, Rana sylvatica, were collected from breeding ponds in the Ottawa area during April 2003. Frogs were washed in a tetracycline bath and held at $5^{\circ} \mathrm{C}$ in a container with damp sphagnum moss for 1-2 weeks before use. Control animals were directly sampled from this condition. For freezing exposure, wood frogs were placed in closed plastic containers lined with damp paper towels and transferred to another incubator at $-4^{\circ} \mathrm{C}$. Under this condition, frogs cool below $0^{\circ} \mathrm{C}$ and start to freeze within $\sim 45 \mathrm{~min}$ (Storey and Storey, 1985a). After this period of chilling, temperature was raised to $-2.5^{\circ} \mathrm{C}$ and the length of freezing exposure was timed from this point. Frogs were sampled after $24 \mathrm{~h}$ of freezing at $-2.5^{\circ} \mathrm{C}$. Other frogs were frozen for $24 \mathrm{~h}$ at $-2.5^{\circ} \mathrm{C}$ and then returned to $5^{\circ} \mathrm{C}$ and allowed to thaw with sampling of these recovered frogs after 8 h. All frogs were killed by pithing and each was dissected within $30-90 \mathrm{sec}$ with the group cooperation of 3-6 persons. Tissues were flash frozen in liquid nitrogen and then transferred for storage to a $-80^{\circ} \mathrm{C}$ freezer. The tissues sampled included brain, heart, liver, kidney and hind leg thigh skeletal muscle.

For anoxia exposure, frogs were treated essentially as described previously (Holden and Storey, 1997). After 1 week acclimation at $5^{\circ} \mathrm{C}$, groups of 5-6 frogs were transferred into closed plastic jars sitting on crushed ice. The jars were lined with damp paper toweling (towels wetted with deoxygenated distilled water) and had been flushed with $100 \%$ nitrogen gas for 20 min through syringe ports in the caps. After the frogs were added the jars were flushed with $\mathrm{N}_{2}$ for a further $20 \mathrm{~min}$ and then the ports were plugged 
and the jar lids were sealed all around with parafilm. Jars were returned to the $5^{\circ} \mathrm{C}$ incubator and frogs were sampled after $24 \mathrm{~h}$ of anoxia exposure. During sampling, the jars were again held on ice and the $\mathrm{N}_{2}$ gassing was reconnected. A third group of frogs was given $24 \mathrm{~h}$ anoxia exposure and were then transferred back to aerobic conditions at $5^{\circ} \mathrm{C}$ and sampled after $4 \mathrm{~h}$ recovery from anoxia.

\section{Western blotting}

\section{Isolation of total protein from frog tissues}

Total soluble protein was extracted from samples of frog tissues from control, 24 $\mathrm{h}$ frozen, $8 \mathrm{~h}$ thawed, 24 hour anoxic and 4 hour recovered (from anoxia) experimental groups. A sample of frozen tissue was weighed and then quickly homogenized 1:5 w:v in buffer containing $20 \mathrm{mM}$ Hepes, $200 \mathrm{mM} \mathrm{NaCl}, 0.1 \mathrm{mM}$ EDTA, $10 \mathrm{mM} \mathrm{NaF}, 1 \mathrm{mM}$ $\mathrm{Na}_{3} \mathrm{VO}_{4}, 10 \mathrm{mM}$ B-glycerophosphate, with fresh prepared protease inhibitors $(0.1 \mathrm{mM}$ phenylmethysulfonyl fluoride [PMSF], $1 \mu \mathrm{g} / \mathrm{ml}$ aprotinin, $1 \mu \mathrm{g} / \mathrm{ml} \mathrm{leupeptin,} 1 \mu \mathrm{g} / \mathrm{ml}$ pepstatin) added just prior to homogenization with a Polytron PT10. Samples were centrifuged at $13,000 \mathrm{rpm}$ for $15 \mathrm{~min}$ at $4^{\circ} \mathrm{C}$ and the supernatant was removed and kept.

\section{Measurement of protein concentration}

Protein concentrations were determined by the Coomassie blue dye-binding method (Bradford, 1976) with the Bio-Rad prepared reagent and bovine serum albumin as the standard. The reagent was diluted 5-fold with distilled water and protein extracts of tissues were diluted 1:50 v:v. For assay, $10 \mu 1$ of diluted protein samples were added 190 $\mu \mathrm{l}$ of dye reagent in microplate wells followed by mixing and a $10 \mathrm{~min}$ incubation at 
$21^{\circ} \mathrm{C}$. Absorbance at $595 \mathrm{~nm}$ was read using a microplate spectrophotometer running BioLinx 2.0 software and protein concentration was determined from a standard curve.

\section{SDS polyacrylamide gel electrophoresis}

Protein samples were mixed 1:1 v:v with SDS-PAGE sample buffer containing $100 \mathrm{mM}$ Tris- $\mathrm{HCl}$ (pH 6.8), 4\% w:v SDS, 20\% v:v glycerol, 5\% v:v 2-mercaptoethanol and $0.2 \% \mathrm{w}: \mathrm{v}$ bromophenol blue and boiled for $5 \mathrm{~min}$. Aliquots containing 20-40 $\mu \mathrm{g}$ protein were loaded into sample wells. On any given gel, the same amount of protein was loaded into each well of $12 \%$ acrylamide gels (acrylamide:bis-acrylamide ratio 29.2:0.8; w/w). Electrophoresis was carried out on a Bio-Rad mini-gel apparatus, run at $180 \mathrm{~V}$ for $30-60 \mathrm{~min}$ at $21^{\circ} \mathrm{C}$ with $1 \mathrm{x}$ running buffer containing $3.03 \mathrm{~g}$ Tris base, $14.4 \mathrm{~g}$ glycine, and $1 \mathrm{~g} \mathrm{SDS}, \mathrm{pH}$ 8.3. Proteins were then transferred to polyvinylidene difluoride (PVDF) membranes (Immobilon-P transfer membrane, Millipore corp. Bedford, MA) at $320 \mathrm{~mA}$ or $70 \mathrm{~V}$ for $1.5 \mathrm{~h}$ at $4^{\circ} \mathrm{C}$ with transfer buffer containing $25 \mathrm{mM}$ Tris $(\mathrm{pH} 8.5), 192 \mathrm{mM}$ glycine and $20 \% \mathrm{v} / \mathrm{v}$ methanol. PVDF membranes were then blocked with $1-2.5 \%$ nonfat

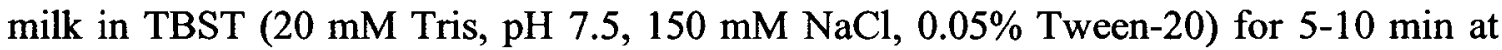
$21^{\circ} \mathrm{C}$ (see Table 2.1 ). Blots were rinsed with TBST and incubated with primary antibody in TBST on a shaking platform either overnight or for 2 days at $4^{\circ} \mathrm{C}$. The dilution of stock primary antibodies used was 1:1000 and these were obtained from Cell Signaling Technology (Beverly, MA). Blots were then washed twice with TBST and incubated with anti-rabbit secondary antibody (Cell Signaling Technology, Beverly, MA) diluted 1:2000 in TBST for $1.5 \mathrm{~h}$ at $21^{\circ} \mathrm{C}$. Blots were washed for $3 \times 10 \mathrm{~min}$ in TBST and then bands were visualized by adding $1.4 \mathrm{ml}$ of enhanced chemiluminescence (ECL) reagent (Pierce) 
with detection and quantification using the Chemi-Genius Bio-Imaging system and Gene Tools software (Syngene, MD, USA).

Total protein was then visualized on the PVDF membrane by staining for $30 \mathrm{~min}$ with Coomassie blue (0.25\% w:v Coomassie Brilliant Blue R, 50\% v:v methanol, $7.5 \%$ $\mathrm{v}: \mathrm{v}$ acetic acid) followed by destaining for $5 \mathrm{~min}$ with destain solution $(50 \mathrm{ml}$ distilled water, $50 \mathrm{ml}$ acetic acid, $150 \mathrm{ml}$ methanol). An appropriate band (or bands) was chosen on each blot as a control and band intensities in each lane were quantified using the SynGene. This was used to confirm equal loading of protein into each lane and immunoblot band intensities in each lane were normalized against the corresponding Coomassie blue "standard" band in that lane. 
Table 2.1: Experimental conditions for Western blotting

\begin{tabular}{|l|c|c|c|c|}
\hline \multicolumn{1}{|c|}{ Proteins } & $\begin{array}{l}\text { Amount of } \\
\text { protein } / \\
\text { lane }(\mu \mathrm{g})\end{array}$ & $\begin{array}{l}\text { Percent } \\
\text { milk used } \\
\text { for blocking }\end{array}$ & $\begin{array}{l}\text { Blocking } \\
\text { time }\end{array}$ & $\begin{array}{l}\text { Incubation time } \\
\text { with primary } \\
\text { antibody }\left(\text { at } 4{ }^{\circ} \mathrm{C}\right)\end{array}$ \\
\hline FOXO1 & 10 & $1.5 \%$ & $5 \mathrm{~min}$ & 2 days \\
\hline $\begin{array}{l}\text { Phospho-FOXO1 } \\
\text { (ser 256) }\end{array}$ & 10 & $1.5 \%$ & $5 \mathrm{~min}$ & 2 days \\
\hline FOXO3 & 20 & $1 \%$ & $10 \mathrm{~min}$ & Overnight \\
\hline $\begin{array}{l}\text { Phospho-FOXO3 } \\
\text { (ser 254) }\end{array}$ & 20 & $2.5 \%$ & $10 \mathrm{~min}$ & Overnight \\
\hline $\begin{array}{l}\text { Phospho-FOXO3 } \\
\text { (ser 318/321) }\end{array}$ & 20 & $2.5 \%$ & $10 \mathrm{~min}$ & Overnight \\
\hline
\end{tabular}




\section{Results}

Several family members of the Forkhead Box Other transcription factors were detected in wood frog tissues: FOXO1, phospho-FOXO1 (Ser 253), FOXO3, phosphoFOXO3 (ser 254) and phospho-FOXO3 (ser 318/321). The tissues scanned included brain, heart, kidney, liver and skeletal muscle. FOXO1 was detected in frog brain, kidney and liver but not in cardiac or skeletal muscles. FOXO3 was detected in frog brain, heart, kidney and liver, but not in skeletal muscle.

\section{FOXO1}

Total FOXO1 protein levels was quantified using Western blotting in wood frog tissues under three experimental conditions: control (acclimated at $5^{\circ} \mathrm{C}$ ), $24 \mathrm{~h}$ frozen (at $-2.5^{\circ} \mathrm{C}$ ) and $8 \mathrm{~h}$ thawed recovery $\left(\right.$ at $5^{\circ} \mathrm{C}$ ) (Figure 2.2). The FOXO1 antibody crossreacted with a single band at the expected molecular weight of $80 \mathrm{kDa}$. A representative of a typical western blot is shown in Figure 2.2 C. FOXO1 protein was detected in the frog brain, kidney and liver. The levels of FOXO1 protein did not change during freezing and thawing in frog brain or liver. In the kidney, the levels of FOXO1 protein decreased significantly $(\mathrm{P}<0.05)$ to just $8.5 \%$ of the control value when frogs were frozen but had increased again to $38.7 \%$ of the control value when animals were thawed for $8 \mathrm{~h}$ at $5^{\circ} \mathrm{C}$.

\section{Phospho-FOXO1 (ser253)}

FOXO1 can be phosphorylated on serine residue 253 and Western blotting was also used to determine the relative amounts of the phosphorylated form of FOXO1 
(ser253) in control, frozen and thawed frogs (Figure 2.3). The phospho-FOXO1 antibody crossreacted with a single band at the expected molecular weight of $80 \mathrm{kDa}$. PhosphoFOXO1 (ser253) was again detected just in brain, kidney and liver. The levels of phospho-FOXO1 (ser253) in the liver did not change significantly during freezing and thawing. However, in brain, the levels of this phosphorylated form of FOXO1 decreased significantly $(\mathrm{P}<0.05)$ to $19.7 \%$ of the control value during freezing and then increased again to $42.6 \%$ of the control value $(\mathrm{P}<0.05)$ when thawed for 8 hours. Levels in the kidney showed a similar pattern, decreasing significantly $(\mathrm{P}<0.05)$ to $2.6 \%$ of the control value when frozen and increasing to $89.4 \%$ of the control value when thawed.

\section{FOXO3-Freeze/Thaw}

The levels of FOXO3 were also examined during freezing and thawing in the wood frog (Figure 2.4). The antibody crossreacted with a single band on the blot at the expected molecular weight $(97 \mathrm{kDa})$ of the protein. Five tissues were tested (brain, liver, heart, kidney, muscle) and the protein was detected in all but skeletal muscle. Total FOXO3 protein levels did not change significantly in the heart and kidney. However, levels increased significantly $(\mathbf{P}<0.05)$ in the brain and liver by 1.6 -fold and 2.2 -fold, respectively, when frogs were frozen for $24 \mathrm{~h}$. Levels decreased again after $8 \mathrm{~h}$ thawing, returning to control levels in brain and to 1.7 -fold above control levels in liver.

\section{Phospho-FOXO3 (ser253) - Freeze/Thaw}

FOXO3 can be phosphorylated on serine 253 and levels of FOXO3 (ser253) were determined in tissues from control, frozen and thawed frogs (Figure 2.5). The antibody 
also crossreacted with a single band on the blot at the expected molecular weight (97 $\mathrm{kDa}$ ) of the protein. Levels in heart and liver did not change significantly during stress/recovery but both brain and kidney showed reduced FOXO3 (ser253) content during freezing. In the brain, the levels of FOXO3 (ser253) dropped significantly $(\mathrm{P}<0.05)$ to $65.1 \%$ and $60.0 \%$ of control values for frozen and thawed tissues, respectively. In the kidney, levels were very strongly suppressed during freezing, decreasing to just $0.7 \%$ of the control value $(\mathrm{P}<0.05)$ and recovering substantially $(53.3 \%$ of control values, $\mathrm{P}<0.05$ ) after $8 \mathrm{~h}$ thawed.

\section{Phospho-FOXO3 (ser 318/321) - Freeze/Thaw}

Antibodies detecting phosphorylation of FOXO3 on serine 318/321 residues were used to quantify the effects of freeze/thaw on these alternate phosphorylation sites on FOXO3 (Figure 2.6). As with the other FOXO3 antibodies, phospho-FOXO3 (ser318/321) only crossreacted with one band at the expected molecular weight of 97 $\mathrm{kDa}$. A significant $(\mathrm{P}<0.05)$ decrease in the content of phosphorylated FOXO3 protein (ser318/321) was observed in all the tissues during freezing. In the brain, phosphoFOXO3 (ser318/321) content decreased significantly to $68.9 \%$ of the control value $(\mathrm{P}<0.05)$ and to $64.7 \%$ of controls when thawed. In the kidney, levels of the phosphorylated transcription factor decreased significantly $(\mathrm{P}<0.05)$ during freezing to $39.6 \%$ of the control value but rose again to $64.9 \%$ of the control value when thawed. In the heart, phospho-FOXO3 (ser318/321) content decreased significantly $(\mathrm{P}<0.05)$ to $55.1 \%$ of the control value during freezing and rose to $88.9 \%$ of the control value when thawed. In the liver, the protein levels decreased significantly $(\mathrm{P}<0.05)$ during freezing to 
$36.4 \%$ of control values and remained suppressed (at $39.4 \%$ of control) when the animals had thawed.

\section{FOXO3- Anoxia/Recovered}

Anoxia/ischemia is one of the components of freezing since when the blood plasma freezes it cuts off oxygenation of the tissues. The levels of FOXO3 were examined in tissues of frogs that were given anoxia exposure for $24 \mathrm{~h}$ (at $5^{\circ} \mathrm{C}$ ) followed by aerobic recovery for $4 \mathrm{~h}$ (also at $5^{\circ} \mathrm{C}$ ) (Figure 2.7). FOXO3 was detected in brain, heart, kidney and liver these animals. The levels of FOXO3 did not change significantly during anoxia or recovery from anoxia in any of the tissues when compared to control values.

\section{Phospho-FOXO3 (ser 318/321) -Anoxia/Recovered}

The levels of phospho-FOXO3 (ser318/321) were also measured in the tissues of the frogs that were given $24 \mathrm{~h}$ anoxia exposure and $4 \mathrm{~h}$ aerobic recovery (Figure 2.8). The results were similar to those seen for the effects of freezing. Phospho-FOXO3 (ser318/321) levels did not change in heart but a significant decrease was seen in brain, kidney and liver. In the brain, the levels dropped significantly $(\mathrm{P}<0.05)$ to $18.3 \%$ of the control value during anoxia and remained low at $16.5 \%$ of the control values during recovery. In the kidney, the levels were very strongly reduced during anoxia to $7.5 \%$ of the control value and again remained low $(6.0 \%$ of control) during aerobic recovery $(\mathrm{P}<0.05)$. In liver tissues, the levels also dropped significantly $(\mathrm{P}<0.05)$ to $4.7 \%$ and $3.1 \%$ in anoxia exposed and aerobic recovery, respectively, compared to control values. 


\section{Discussion}

A change in the expression of Forkhead box other (FOXO) proteins 1 and 3 was hypothesized during the freeze/thaw process of the wood frog Rana sylvatica. A change in the expression of FOXO3 was also hypothesized to be involved in the anoxia/recovery process of the wood frog. The data presented here evaluates these hypotheses.

\section{FOXO1}

FOXO transcription factors are under the control of insulin and/or insulin-like signaling factors. FOXO factors are phosphorylated by various protein kinases, one of the main ones being Protein Kinase B (PKB), a downstream mediator of phosphoinositide-3 kinase (PI3K) signaling. Phosphorylation of FOXOs results in their inactivation and nuclear exclusion (Biggs et al., 1999). All FOXO proteins contain three highly conserved putative PKB recognition motifs (Alessi et al., 1996a). They have also been shown to require the consensus $\mathrm{N}$-terminal PKB site and the PKB site located in the forkhead domain to translocate from the nucleus to the cytosol (Brownawell et al., 2001). Serum and glucocorticoid-regulated kinase (SGK), a structurally related family member of PKB, also phosphorylates FOXO factors. PKB and SGK are both activated by the PI3K / PDK1 cascade and are both able to phosphorylate identical substrate motifs, but with different preferences. SGK prefers the third C-terminal PKB motif (Brunet et al., 2001). Casein kinase $1(\mathrm{CK} 1)$ recognizes and phosphorylates FOXO motifs that have been primed (motifs that already contain a phosphorylated serine or threonine residue) (Flotow et al., 1990). Dual-specificity tyrosine-phosphorylated and-regulated kinase 1A (DYRK1A) 
also phosphorylates FOXO factors and is involved in the subcellular localization of FOXO proteins (Woods et al., 2001).

FOXO transcription factors have important roles in various cellular processes such as metabolism, cellular proliferation, stress tolerance and lifespan (van der Horst and Burgering, 2007). FOXOs regulate the expression of genes coding for enzymes such as phosphoenolpyruvate carboxykinase (PEPCK) and glucose-6-phosphatase, which are essential regulators of gluconeogenesis (Nakae et al., 2001). They can also suppress the expression of genes that are involved in glycolysis, the pentose shunt and lipogenesis, which implies that they induce a metabolic switch similar to low glucose and fasting conditions (Zhang et al., 2006). In the absence of insulin signaling, FOXOs also induce cell-cycle inhibition, through regulation of cell-cycle arrest genes such as $\mathrm{p} 27^{\mathrm{kipl}}$ and cyclin D (Kops et al., 2002a).

In the current study, the levels of FOXO1 and a phosphorylated form of FOXO1 were assessed in control (acclimated at $5^{\circ} \mathrm{C}$ ), $24 \mathrm{~h}$ frozen (at $-2.5^{\circ} \mathrm{C}$ ) and $8 \mathrm{~h}$ thawed (at $5^{\circ} \mathrm{C}$ ) wood frogs in 5 tissues (brain, heart, kidney, liver, muscle). FOXO1 was not detected in heart or muscle, which was initially unexpected, since FOXO1 was found to be active in mammalian skeletal muscle during energy deprivation (Furuyama et al., 2003). An explanation for this result could be that the levels of FOXO1 in frog muscle and heart are too low to be detected, or that the wood frog is not really in an energy deprived state when frozen. Although energy production slows to $5 \%$ of normal, energy utilization slows to $2 \%$ of normal which implies that energy deprivation is not a factor (Storey and Storey, 2004a). FOXO1 levels in frog brain did not change significantly. Since the antibody used to detect the amount of FOXO1 does not distinguish between the 
unphosphorylated form and the phosphorylated forms of FOXO1, this result shows the total amount of FOXO1 (phosphorylated and unphosphorylated) does not change significantly when the wood frog freezes. In other words, FOXO1 is not degraded in the brain during freezing. However, the amount of the phosphorylated form of FOXO1 (ser256) decreased significantly when the wood frog freezes and the levels slowly increased again when the frogs thawed. When FOXOs are phosphorylated, they are inactivated (Biggs et al., 1999). Hence, the lower amount of the phosphorylated form of FOXO1 in the brain implies that this transcription factor is more active in the brain during freezing. In the kidney, total FOXO1 protein decreased during freezing to low levels, and then increased again during thawing process. The same trend was observed in the amount of phospho-FOXO1 (ser256) detected in the kidney when frozen and thawed. These results indicate that FOXO1 is degraded in the kidney when frogs freeze. It also implies that FOXO1 is not more active in the kidney during freezing. The levels of FOXO1 and phospho-FOXO1 (ser256) in the frog liver during freezing and thawing did not change significantly. It appears as if FOXO1 is not important for freeze tolerance in the frog liver.

FOXO1 is involved in the upregulation of genes, such as glucose-6-phosphatase (G6Pase) and phosphoenolpyruvate carboxykinase (PEPCK), that are involved in gluconeogenesis, a process where glucose is generated from non-sugar substrates. PEPCK is the first committed step in gluconeogenesis, while G6Pase removes the phosphate group from glucose 6-phosphate and is the last step in gluconeogenesis (Hers and Hue, 1983). Glucose is the sole energy source for the brain. During freezing in wood frogs, glucose is used as a cryoprotectant and is synthesized by the liver and quickly 
distributed to other organs, to levels that rise into the $200 \mathrm{mM}$ range (from control values of $\sim 5 \mathrm{mM}$ ) (Storey, 1987). Since the glucose available is needed as a cryoprotectant, another way to generate glucose needed for energy in the brain might be needed: gluconeogenesis. If gluconeogenesis is used to produce energy in the brain during freezing, an activation of FOXO1 in the brain is expected since FOXO1 upregulates genes involved in gluconeogenesis. The very low amounts of total FOXO1 protein detected during freezing in the kidney and the increasing amount of FOXO1 protein in the kidney when thawing implies that FOXO1 is not needed for freeze-tolerance in the frog kidney. The liver did not show any significant change of total FOXO1 and phosphoFOXO1 (ser256) which also implies the insignificance of this protein in the freezetolerance of the liver in the wood frog.

\section{FOXO3 in Anoxia-tolerance}

The levels of FOXO3 and a phosphorylated form of FOXO3 (ser 318/321) were assessed in control (acclimated at $\left.5^{\circ} \mathrm{C}\right), 24$ hour anoxic $\left(\right.$ at $5^{\circ} \mathrm{C}$ ) and 4 hour recovered from anoxia (also at $5^{\circ} \mathrm{C}$ ). One of the components of total body freezing is anoxia/ischemia caused by the freezing of blood plasma. This means that each cell in each organ is isolated and cut off from the delivery of oxygen (and nutrients) for the duration of the freeze. The involvement of FOXO3 in anoxia tolerance in wood frogs was evaluated because FOXO3 is well-known to be involved in antioxidant defense (Kops et $a l ., 2002 \mathrm{~b}$ ). In mammalian systems of anoxia/ischemia, a large portion of the metabolic damage is not actually caused by oxygen deprivation itself but by the rapid production of high amounts of reactive oxygen species when oxygen is suddenly reintroduced by 
organs. Hence, good antioxidant defenses are needed to counter this reperfusion injury. The levels of FOXO3 and its phosphorylated form were determined in the brain, heart, kidney, liver and muscle. There was no expression in muscle, probably due to the inability to detect low enough levels of the transcription factor in muscle. FOXO3 was found in all other tissues, and total levels of FOXO3 did not change during anoxia and recovery in any of these tissues. Since the antibody used does not distinguish between unphosphorylated FOXO3 and phosphorylated FOXO3, this result implies that there is no change in the amount of total FOXO3 in the three states. A different result was observed when specific phosphorylation of the transcription factor at the serine $318 / 321$ sites was examined. There was no significant change in the amount of phospho-FOXO3 (ser318/321) during anoxia and recovery in the heart but in brain, kidney and liver a strong and significant $(\mathrm{P}<0.05)$ reduction in the amount of phospho-FOXO3 (ser318/321) was seen during anoxia and recovery. Since the phosphorylated form of FOXO3 is the inactive form, this result means that there is less inactive FOXO3 in the brain, kidney and liver during anoxia and recovery. If the unphosphorylated FOXO3 and the phosphorylated FOXO3 data for anoxia and recovery are taken together, the lack of change in $\mathrm{FOXO} 3$ and the large reduction in phosphorylated FOXO3 (in brain, kidney and liver) implies that $\mathrm{FOXO} 3$ is more active during anoxia and recovery compared to control frogs. FOXO3 is involved in antioxidant defense by controlling the expression of the antioxidant enzymes such as MnSOD and catalase (Kops et al., $2002 \mathrm{~b}$ and Nemoto and Finkel, 2002). The data suggest that antioxidant defenses are present, and potentially enhanced, in the brain, kidney and liver during anoxia and recovery in the wood frog. 


\section{FOXO3 in freeze-tolerance}

FOXO3 levels were also assessed in control (acclimated to $5^{\circ} \mathrm{C}$ ), $24 \mathrm{~h}$ frozen (at $-2.5^{\circ} \mathrm{C}$ ) and $8 \mathrm{~h}$ thawed $\left(\right.$ at $5^{\circ} \mathrm{C}$ ) frogs. The total content of FOXO3 in kidney and heart did not change significantly $(\mathrm{P}<0.05)$ during freezing and thawing, but rose substantially (1.5-2 fold) in the brain and liver. Two different phosphorylation states of FOXO3 were also evaluated, one at ser 253 and the second at ser318/321. For phospho-FOXO (ser 253), the amount of this phosphorylated form did not change in the heart or liver, but did decreased significantly in the brain and kidney when the frogs were frozen and when they were thawing. These results imply that FOXO3 is more active in the brain and kidney during freezing and thawing. The response by phospho-FOXO3 (ser318/321) was slightly different: the phosphorylated content decreased significantly in all frozen tissues and remained low after $8 \mathrm{~h}$ thawed. The reduced levels of phospho-FOXO3 (ser318/321) were expected in the brain and kidney during freezing, but the decreased levels in the liver and heart were unexpected since the levels did not change when assessing the levels of phospho-FOXO3 (ser253). An explanation for this differential expression of phosphorylated FOXO3 forms is that the two phosphorylation sites of FOXO3 that were assessed are phosphorylated by (and under the control of) different protein kinase enzymes. The serine 253 position is phosphorylated by $\mathrm{PKB}$, a main regulator of $\mathrm{FOXO}$ function (van der Heide et al., 2004), whereas the serine 318/321 position is phosphorylated by CK1. It has been shown that CK1 phosphorylation of the serine 318/321 position is dependent on initial phosphorylation of the C-terminal PKB site (serine 253) (Woods et al., 2002). FOXOs have also been described as being "fine-tuned" by CK1, which implies a differential regulation of FOXO3 in the liver compared to the 
kidney and brain (van der Heide et al., 2004). The reduced level of phosphorylated FOXO3 in the brain, kidney and liver, equaling a more active FOXO3 in these tissues, implies that this transcription factor is important in survival of the wood frog during freezing.

\section{Conclusion}

FOXO1 was found to be more active (lower amounts of phosphorylated FOXO1) in the brain of $24 \mathrm{~h}$ frozen and 8 hour thawed wood frogs, when compared to controls. FOXO3 was also more active in the brain, kidney and liver during $24 \mathrm{~h}$ anoxia exposure and when recovered from anoxia for 4 hours, and it was also more active in higher quantity in the brain, kidney and liver during freezing and thawing. The increase in active FOXO1 in the brain could be due to a need for gluconeogenesis in this tissue during freezing. FOXO1 has been shown to upregulate the gene expression of enzymes such as PEPCK and G6Pase which are essential regulators of gluconeogenesis (Barthel et al., 2001). The increase in active FOXO3 in brain, heart, kidney and liver during freezing and thawing, and the increase in the brain, kidney and liver during anoxia and recovery from anoxia could be due to a need to maintain or enhance antioxidant defenses during freezing or anoxia. The reperfusion of blood creates a large amount of oxygen free radicals, and FOXO3 upregulates enzymes such as MnSOD and catalase which protect cells from damage caused by oxygen free radicals (Kops et al., 2002b; Nemoto and Finkel, 2002). FOXO3 was also found to upregulate fatty acyl-CoA carriers sterol carrier protein-x (SCPx) and SCP2 which protect unsaturated fatty acids from oxidative damage (Dansen et al., 2004). Another explanation for the activation of FOXO transcription 
factors is that FOXO factors induce cell-cycle inhibition by regulating factors such as p2 $7^{\text {kipl }}, \mathrm{p} 130 \mathrm{Rb} 2$, cyclin D and cyclin $\mathrm{G} 2$ which stimulate cells to enter a quiescent state (Kops et al., 2002a). This quiescent state enables survival (extends viability) under fasting or other stressful conditions. It is difficult to determine the exact function of FOXO factors during freezing or anoxia, but since they are more active during these stresses, when many aspects of cell function are suppressed or shut down, this shows the importance of gene regulation by FOXO transcription factors when the wood frog is frozen or anoxic. 


\section{Figure 2.1}

(A) PKB/Akt signal transduction pathway regulating FOXO transcription factors.

(B) Kinases that phosphorylate FOXOs (murine)and their phosphorylation sites 
Figure 2.1

(A)

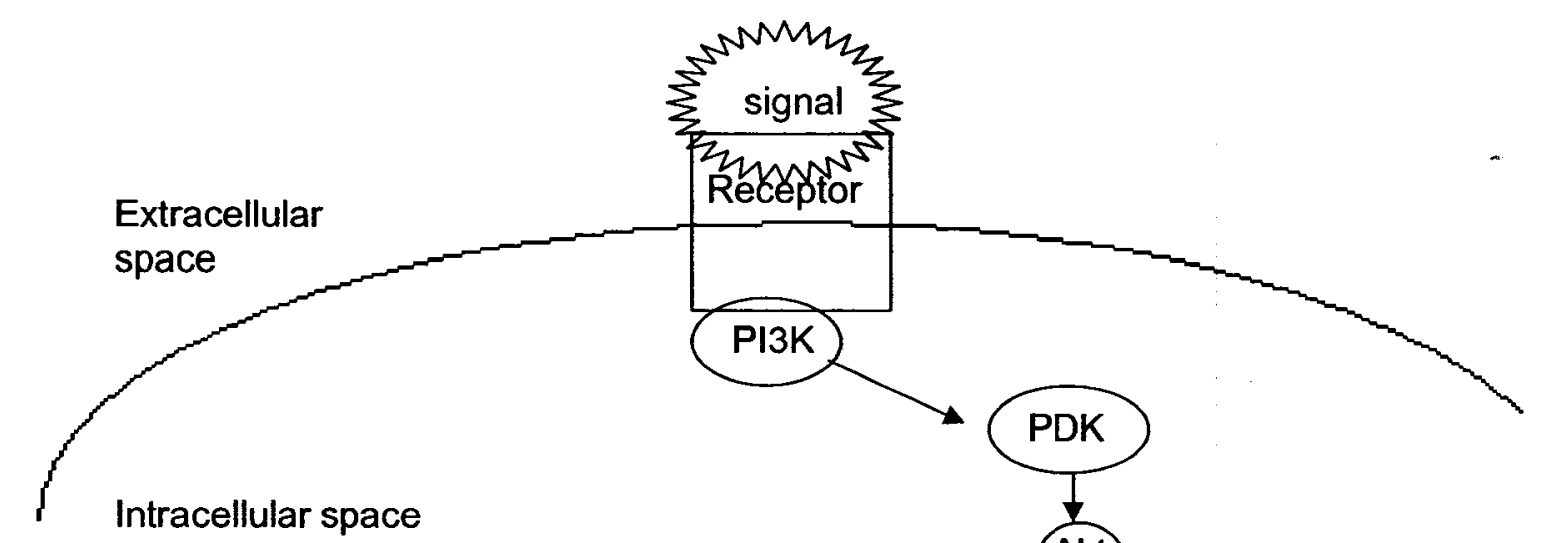

Akt

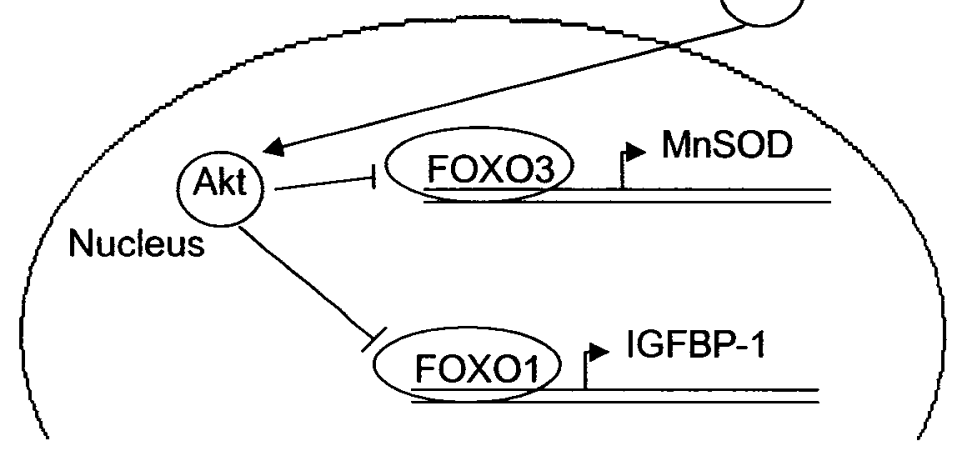

(B)

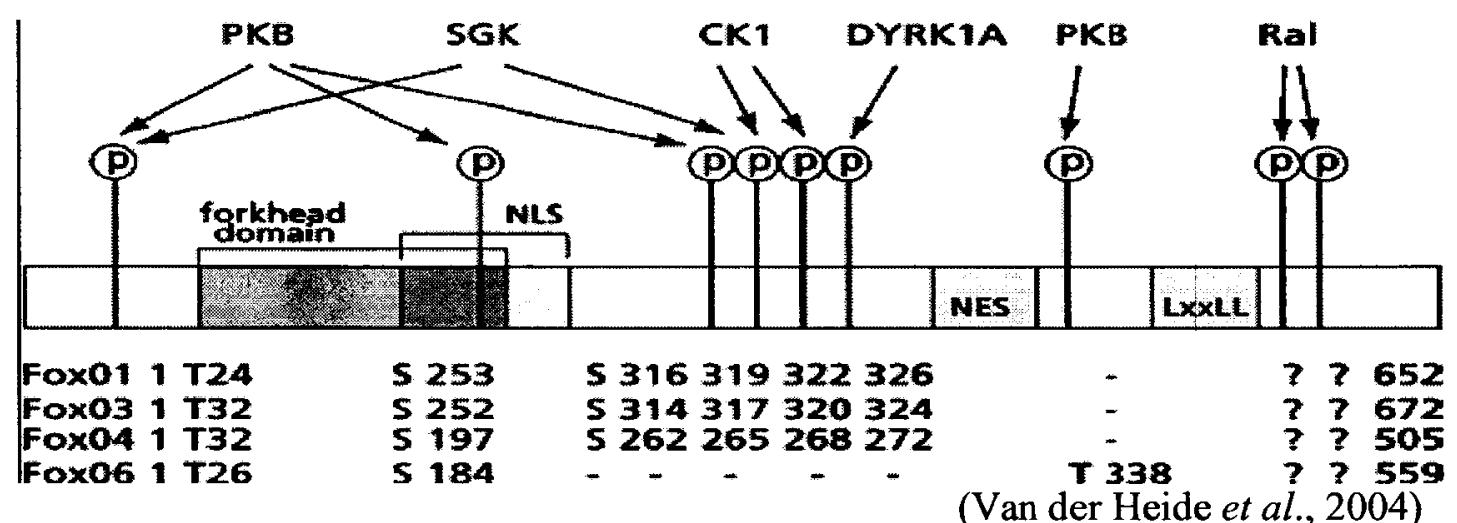

(Van der Heide et al., 2004) 


\section{Figure 2.2}

Western blot analysis of FOXO1 protein content in brain, kidney and liver of wood frogs from three conditions: control $\left(5^{\circ} \mathrm{C}\right.$ acclimated), frozen $\left(24 \mathrm{~h}\right.$ at $\left.-2.5^{\circ} \mathrm{C}\right)$ and thawed $(8 \mathrm{~h}$ at $5^{\circ} \mathrm{C}$ after $24 \mathrm{~h}$ frozen)

(A) Representative Western blots showing FOXO1 protein levels in tissues from control $(\mathrm{C})$, frozen $(\mathrm{F})$ and thawed $(\mathrm{T})$ frogs.

(B) Relative levels of FOXO1 protein in frozen and thawed frogs as compared with controls. Histograms shows mean \pm SEM, $n=4$ independent determinations.

Stars show values that are significantly different from the corresponding control for the same tissue as determined by the Student's t-test, $\mathrm{P}<0.05$.

(C) Typical Western blot showing the antibody (FOXO1) crossreacting with a single band on the blot at the expected molecular weight $(80 \mathrm{kDa})$.

(D) Typical Coomassie blue stained gel to determine relative protein levels. 
Figure 2.2

(A)

Brain

\section{C $F$ T}

Kidney

\section{Liver}

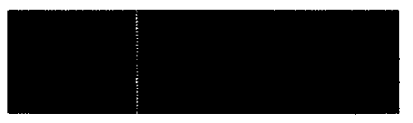

(B)

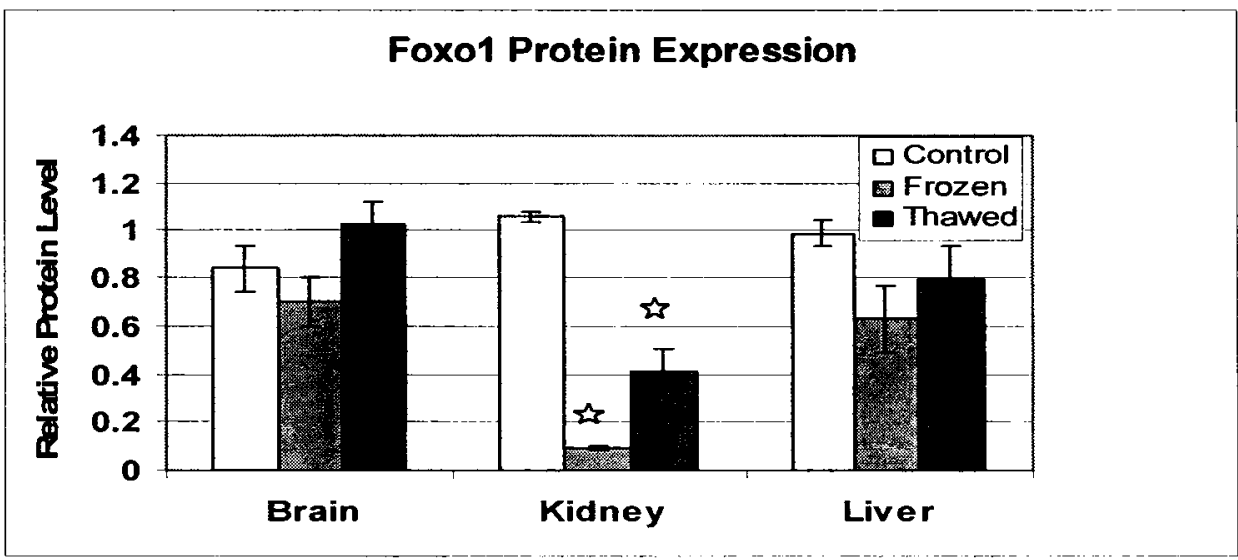

(C)

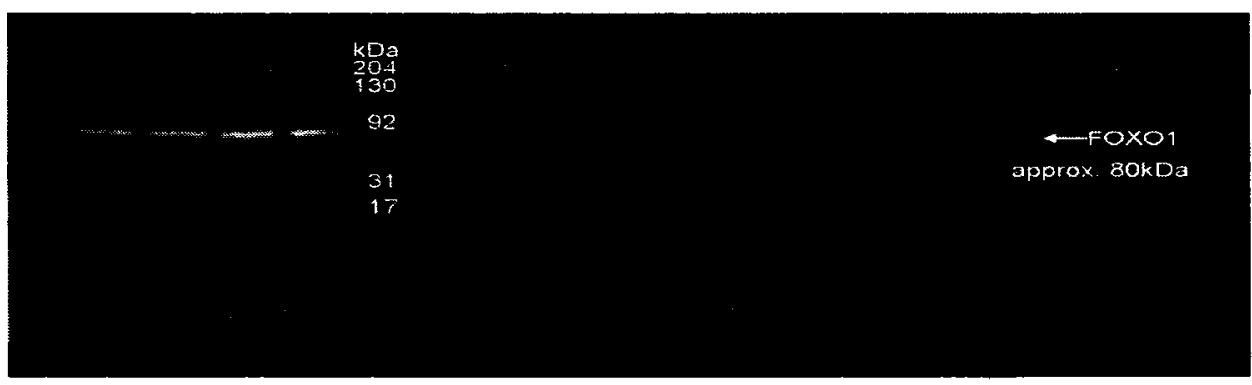

(D)

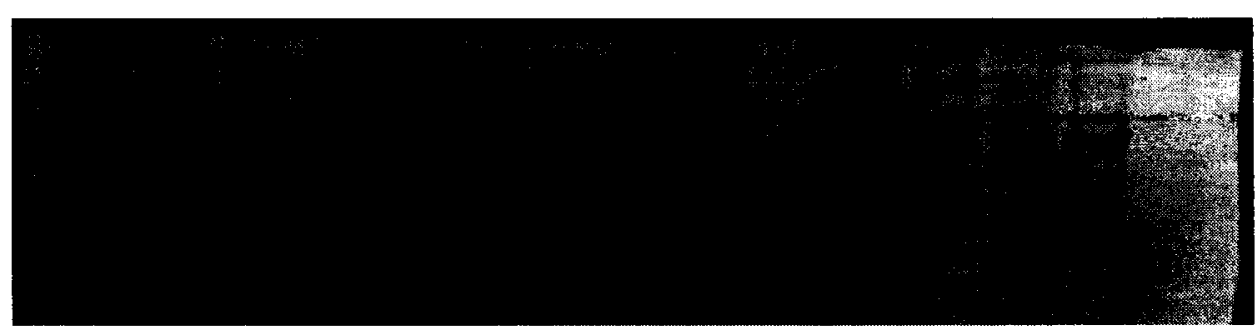




\section{Figure 2.3}

Western blot analysis of phospho-FOXO1 (ser 256) protein content in brain, kidney and liver of wood frogs from three conditions: control $\left(5^{\circ} \mathrm{C}\right.$ acclimated), frozen $(24 \mathrm{~h}$ at $\left.-2.5^{\circ} \mathrm{C}\right)$ and thawed $\left(8 \mathrm{~h}\right.$ at $5^{\circ} \mathrm{C}$ after $24 \mathrm{~h}$ frozen)

(A) Representative Western blots showing phospho-FOXO1 (ser256) protein levels in tissues from control (C), frozen (F) and thawed (T) frogs.

(B) Relative levels of phospho-FOXO1 (ser256) protein in frozen and thawed frogs as compared with controls. Histograms shows mean $\pm S E M, n=4$ independent determinations.

Stars show values that are significantly different from the corresponding control for the same tissue as determined by the Student's t-test, $\mathrm{P}<0.05$. 
Figure 2.3

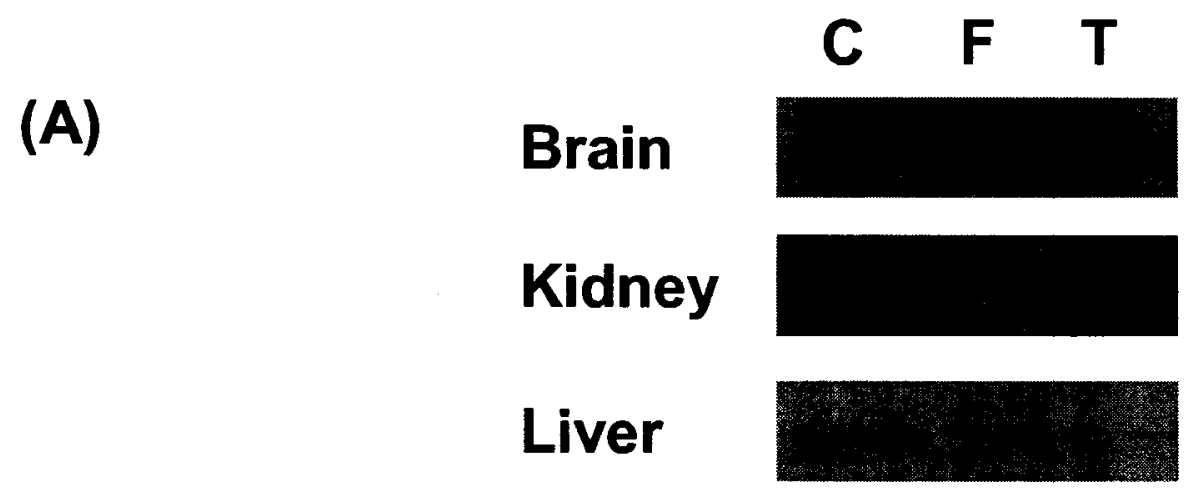

(B)

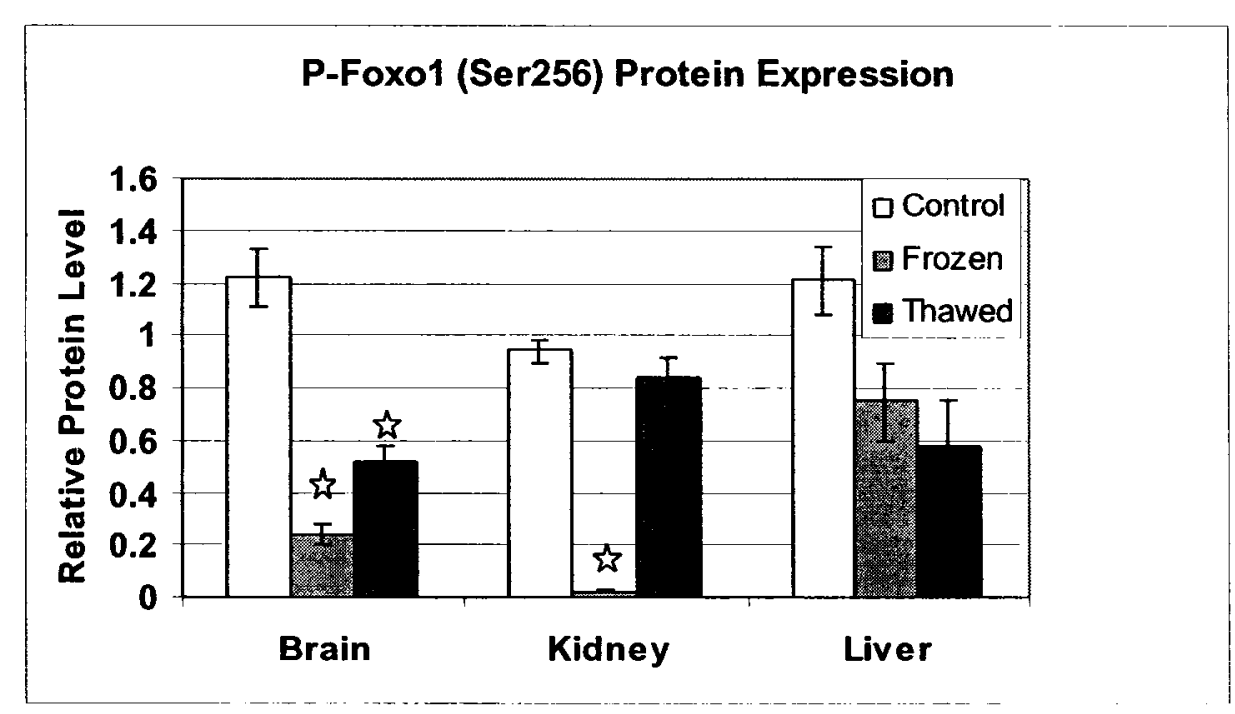




\section{Figure 2.4}

Western blot analysis of FOXO3 protein content in brain, heart, kidney and liver of wood frogs from three conditions: control $\left(5^{\circ} \mathrm{C}\right.$ acclimated $)$, frozen $\left(24 \mathrm{~h}\right.$ at $\left.-2.5^{\circ} \mathrm{C}\right)$ and thawed ( $8 \mathrm{~h}$ at $5^{\circ} \mathrm{C}$ after $24 \mathrm{~h}$ frozen)

(A) Representative Western blots showing FOXO3 protein levels in tissues from control (C), frozen (F) and thawed (T) frogs.

(B) Relative levels of FOXO3 protein in frozen and thawed frogs as compared with controls. Histograms shows mean \pm SEM, $n=4$ independent determinations.

Stars show values that are significantly different from the corresponding control for the same tissue as determined by the Student's t-test, $\mathrm{P}<0.05$. 
Figure 2.4

(A)

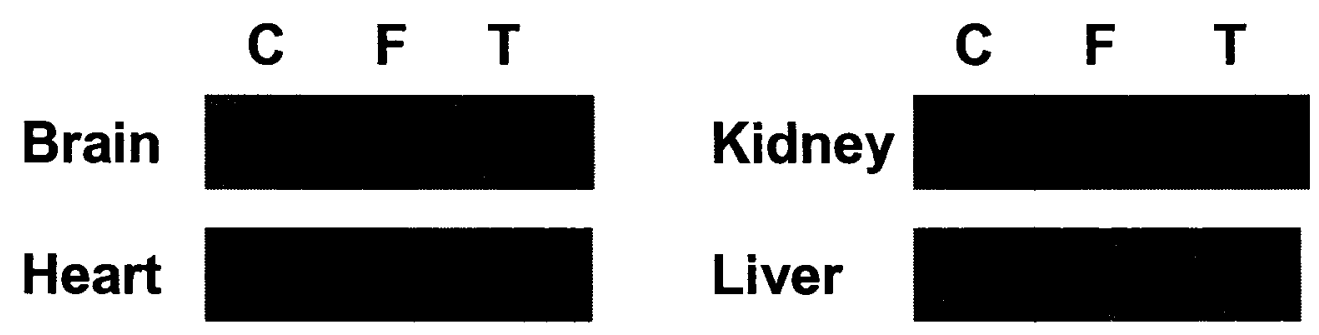

(B)

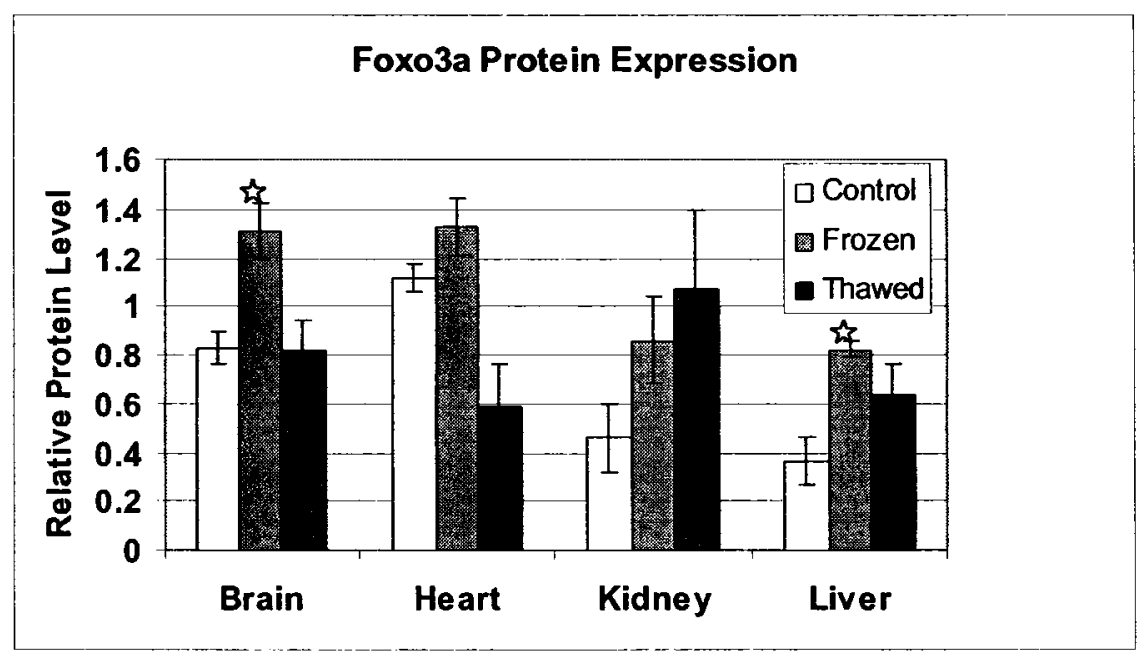


Figure 2.5

Western blot analysis of phospho-FOXO3 (ser 253) protein content in brain, heart, kidney and liver of wood frogs from three conditions: control $\left(5^{\circ} \mathrm{C}\right.$ acclimated $)$, frozen $\left(24 \mathrm{~h}\right.$ at $\left.-2.5^{\circ} \mathrm{C}\right)$ and thawed $\left(8 \mathrm{~h}\right.$ at $5^{\circ} \mathrm{C}$ after $24 \mathrm{~h}$ frozen $)$.

(A) Representative Western blots showing phospho-FOXO3 (ser253) protein levels in tissues from control (C), frozen (F) and thawed (T) frogs.

(B) Relative levels of phospho-FOXO3 (ser253) protein in frozen and thawed frogs as compared with controls. Histograms shows mean \pm SEM, $n=4$ independent determinations.

Stars show values that are significantly different from the corresponding control for the same tissue as determined by the Student's t-test, $\mathrm{P}<0.05$. 
Figure 2.5

(A)

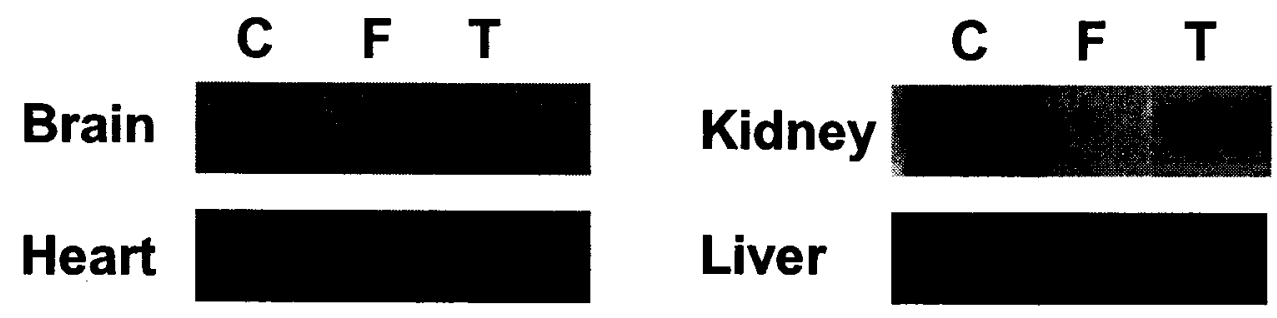

(B)

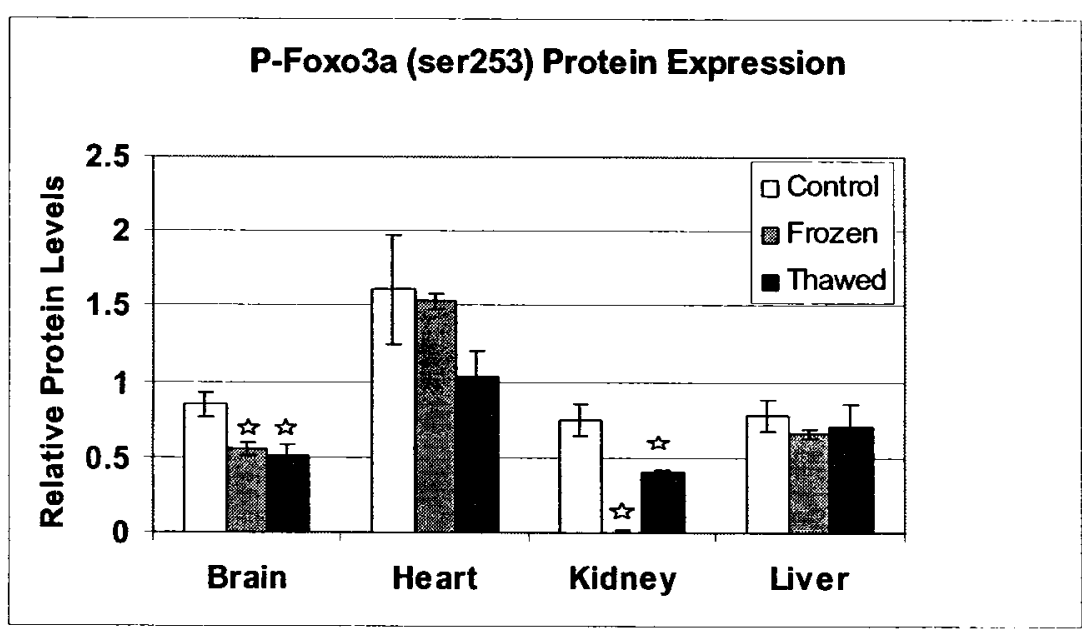




\section{Figure 2.6}

Western blot analysis of phospho-FOXO3 (ser 318/321) protein content in brain, heart, kidney and liver of wood frogs from three conditions: control $\left(5^{\circ} \mathrm{C}\right.$ acclimated $)$, frozen (24 $\mathrm{h}$ at $\left.-2.5^{\circ} \mathrm{C}\right)$ and thawed $\left(8 \mathrm{~h}\right.$ at $5^{\circ} \mathrm{C}$ after $24 \mathrm{~h}$ frozen)

(A) Representative Western blots showing phospho-FOXO3 (ser318/321) protein levels in tissues from control (C), frozen (F) and thawed (T) frogs.

(B) Relative levels of phospho-FOXO3 (ser318/321) protein in frozen and thawed frogs as compared with controls. Histograms shows mean $\pm \mathrm{SEM}, \mathrm{n}=4$ independent determinations.

Stars show values that are significantly different from the corresponding control for the same tissue as determined by the Student's t-test, $\mathrm{P}<0.05$. 
Figure 2.6

(A)

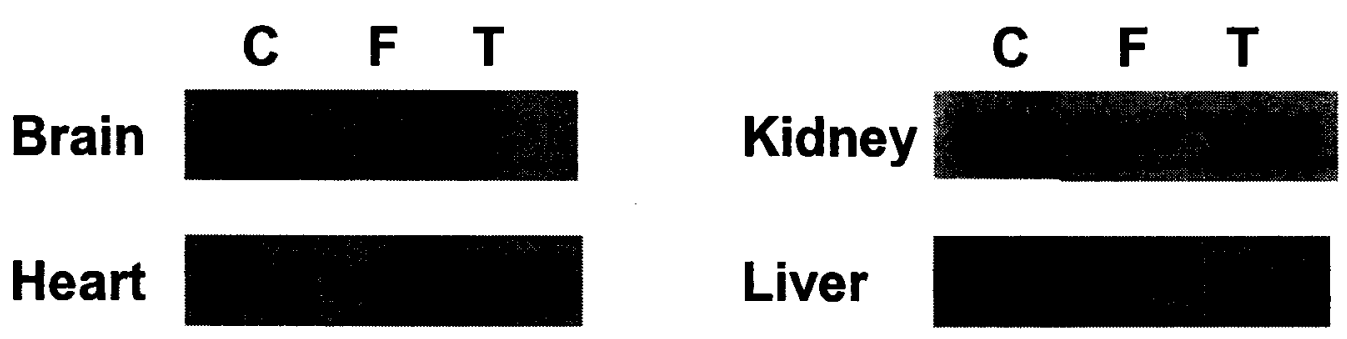

(B)

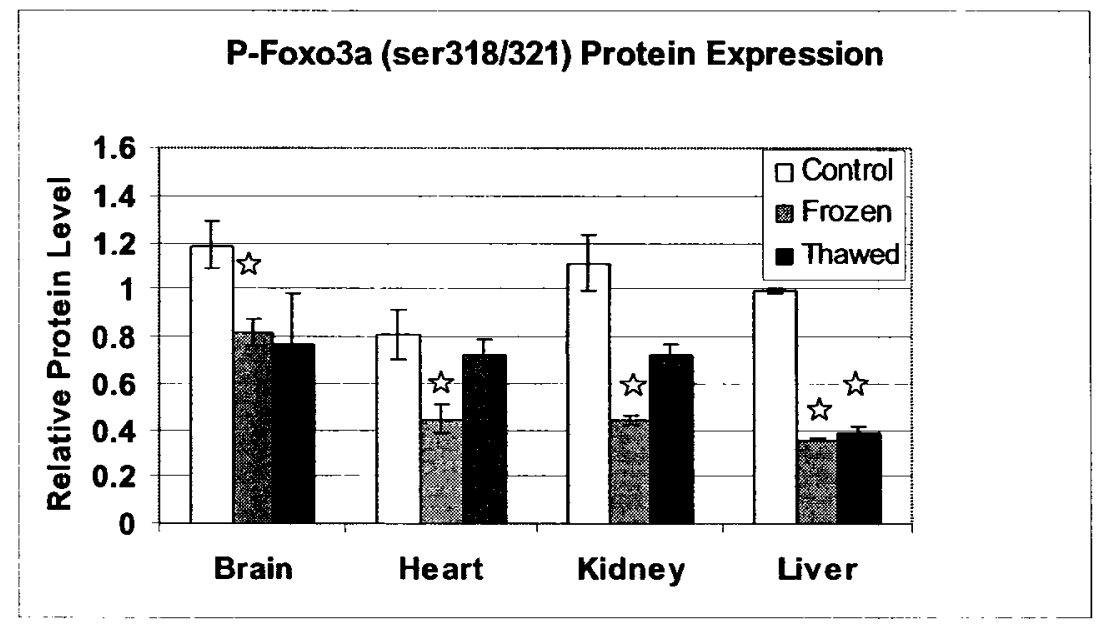


Figure 2.7

Western blot analysis of FOXO3 protein content in brain, heart, kidney and liver of wood frogs from three conditions: control $\left(5^{\circ} \mathrm{C}\right.$ acclimated $)$, anoxic $\left(24 \mathrm{~h}\right.$ at $\left.5^{\circ} \mathrm{C}\right)$ and aerobic recovery $\left(4 \mathrm{~h}\right.$ at $5^{\circ} \mathrm{C}$ after $24 \mathrm{~h}$ anoxic)

(A) Representative Western blots showing FOXO3 protein levels in tissues from control (C), anoxic (A) and recovered (R) frogs.

(B) Relative levels of FOXO3 protein in frozen and thawed frogs as compared with controls. Histograms shows mean $\pm \mathrm{SEM}, \mathrm{n}=4$ independent determinations.

Stars show values that are significantly different from the corresponding control for the same tissue as determined by the Student's t-test, $\mathrm{P}<0.05$. 
Figure 2.7

(A)
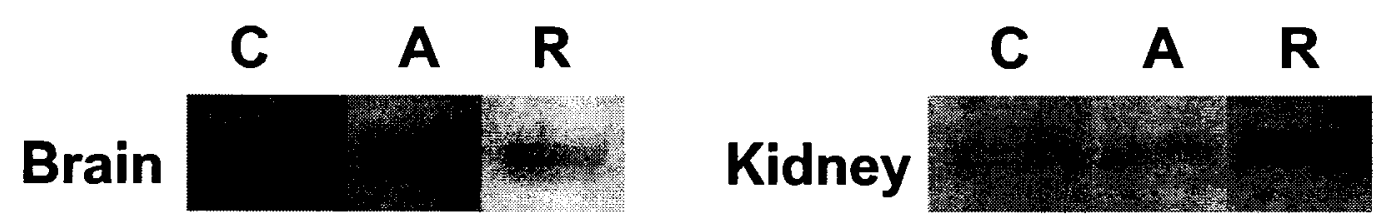

Heart

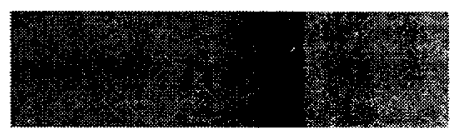

Liver

(B)

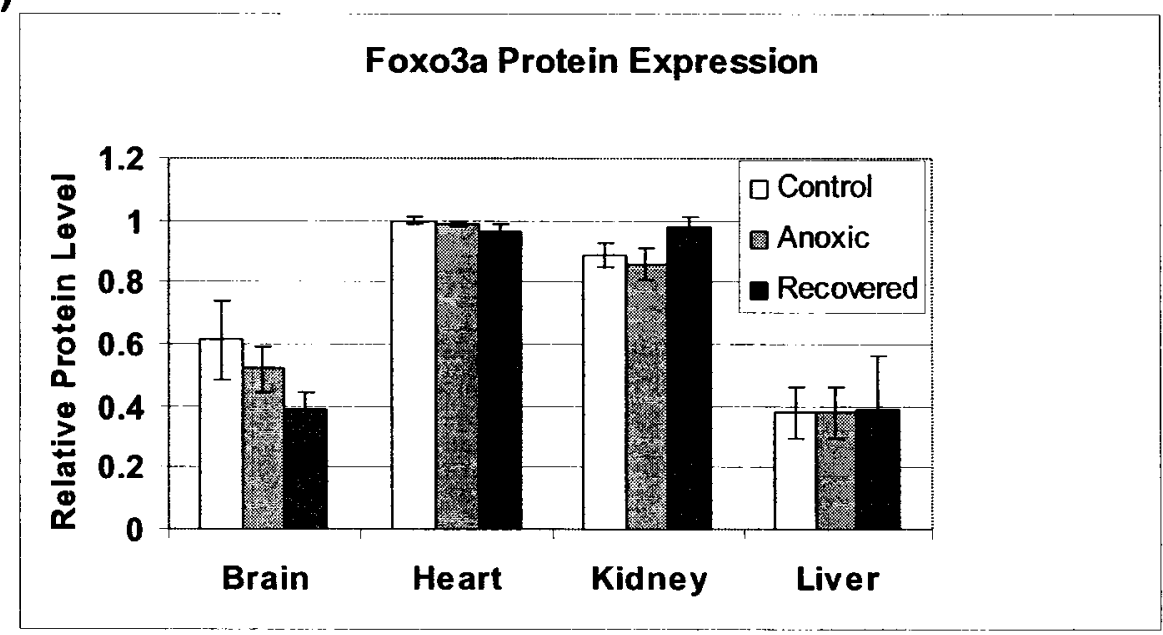




\section{Figure 2.8}

Western blot analysis of phospho-FOXO3 (ser318/321) protein content in brain, heart, kidney and liver of wood frogs from three conditions: control $\left(5^{\circ} \mathrm{C}\right.$ acclimated), anoxic $\left(24 \mathrm{~h}\right.$ at $\left.5^{\circ} \mathrm{C}\right)$ and aerobic recovery $\left(4 \mathrm{~h}\right.$ at $5^{\circ} \mathrm{C}$ after $24 \mathrm{~h}$ anoxic)

(A) Representative Western blots showing phospho-FOXO3 (ser318/321) protein levels in tissues from control (C), anoxic (A) and recovered (R) frogs.

(B) Relative levels of phospho-FOXO3 (ser 318/321) protein in frozen and thawed frogs as compared with controls. Histograms shows mean $\pm S E M, n=4$ independent determinations.

Stars show values that are significantly different from the corresponding control for the same tissue as determined by the Student's t-test, $\mathrm{P}<0.05$. 
Figure 2.8

(A)

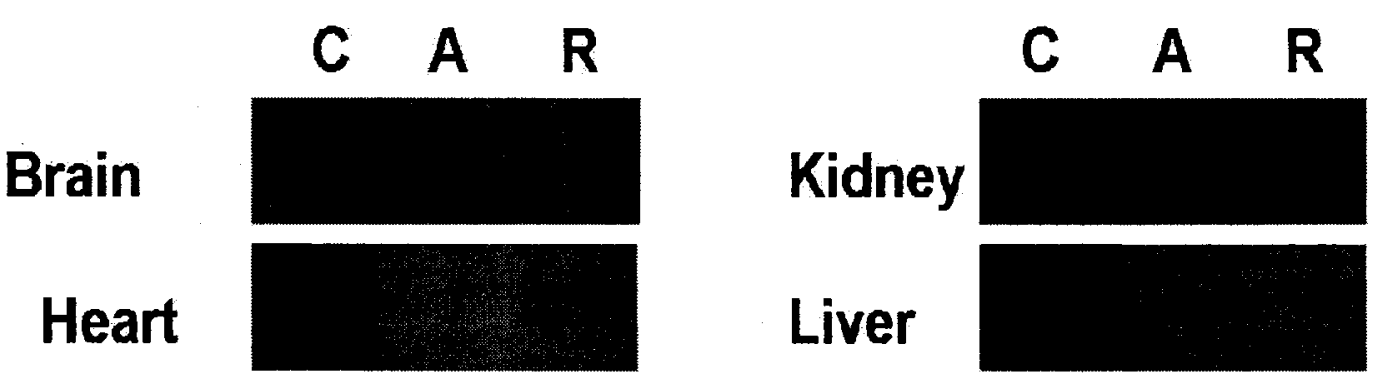

(B)

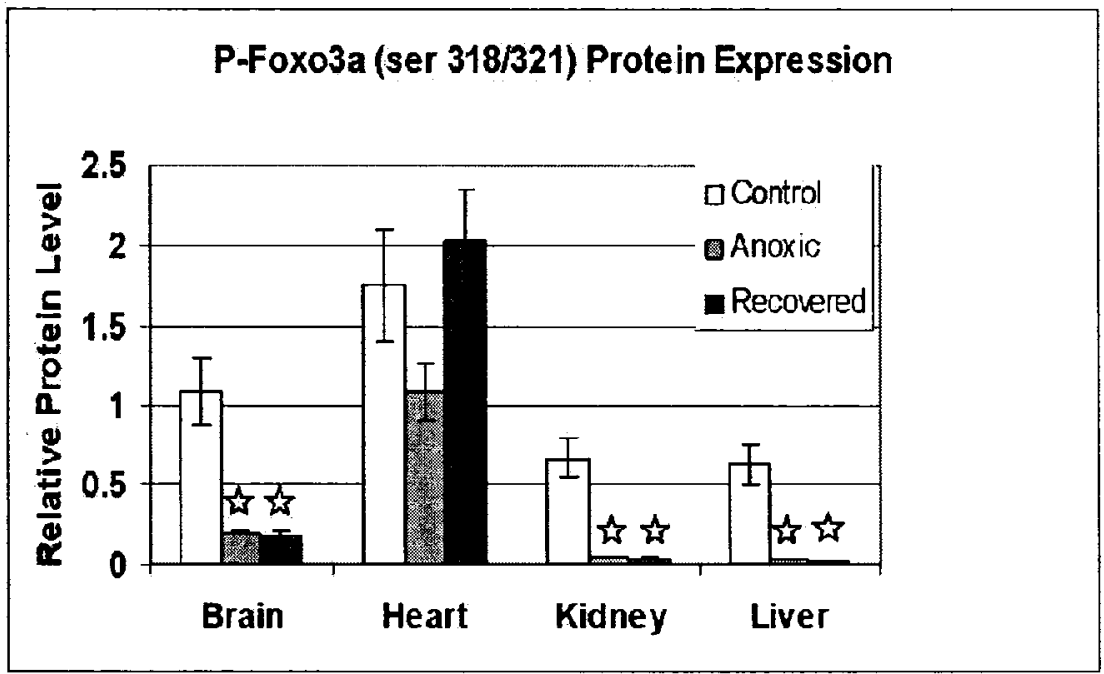




\section{CHAPTER 3:}

\section{Regulation of Glycogen Synthase Kinase 3}




\section{Introduction}

Glycogen synthase kinase 3 (GSK3) is a serine/threonine kinase, once thought to be capable only of phosphorylating and inactivating glycogen synthase, the final enzyme in glycogen biosynthesis (Embi et al., 1980). In mammals, there are two closely related isoforms, GSK3 $\alpha(51 \mathrm{kDa})$ and GSK3 $\beta(47 \mathrm{kDa})$, which are ubiquitously expressed in tissues (Woodgett, 1991). The difference in molecular weight between the two isoforms is mainly due to a glycine-rich extension at the N-terminus of GSK3 $\alpha$ (Woodgett, 1990). When cells are stimulated by insulin, inactivation of GSK3 occurs through a phosphoinositide 3-kinase (PI3K)-dependent mechanism. PI3K-induced activation of protein kinase $\mathrm{B}$ (PKB, also known as Akt) results in $\mathrm{PKB}$ phosphorylation of both GSK3 isoforms (on serine 9 for GSK3 $\beta$ and serine 21 for GSK3 $\alpha$ ), which consequently inhibits GSK3 activity (Cross et al., 1995). By inhibiting GSK3, glycogen synthase can then be activated allowing the insulin-stimulated uptake of glucose into cells to be channeled into glycogen synthesis. GSK3 can also be phosphorylated on ser $9 /$ ser 21 by the most downstream kinase of the classical mitogen-activated protein kinase (MAPK) cascade, called MAPK-activated protein kinase-1 (MAPKAP-K1, also known as RSK) (Saito et al., 1994). Many other stimuli also cause the inactivation of GSK3 by phosphorylation of the serine residues: activators of p70 ribosomal S6 kinase (p70S6K) such as amino acids, activators of cAMP-activated protein kinase (PKA) and protein kinase C (PKC) activators (Armstrong et al., 2001; Fang et al., 2000, 2002).

The specificity of GSK3 for its substrates is exceptional since it requires a priming phosphate at $n+4$ (where $n$ is the site of phosphorylation by GSK3). The optimal consensus site for phosphorylation is Ser/Thr-Xaa-Xaa-Xaa-pSer/pThr (where Xaa is any 
amino acid and pSer/pThr is either phosphoserine or phosphothreonine) (Fiol et al., 1987).

Substrates phosphorylated by GSK3 have roles in many different cellular processes, which include glycogen metabolism, transcription, translation, cytoskeletal regulation, intracellular vesicular transport, cell cycle progression and apoptosis. Phosphorylation of protein substrates by GSK 3 is usually inhibitory. GSK 3 phosphorylates and inactivates a variety of transcription factors such as $\beta$-catenin (transcription transactivator), c-Jun (component of activator protein-1 which regulates many diverse genes), c-Myc (regulates genes involved in cell growth, differentiation and apoptosis) and cyclin D1 (cell cycle regulation) (Yost et al., 1996; Boyle et al., 1991; Pulverer et al., 1994; Diehl et al., 1998). GSK3 action can also increase the transcriptional activity of some transcription factors such as the cAMP response element binding protein which regulates cAMPresponsive genes (Fiol et al., 1994). GSK3 also inhibits the activity of several enzymes including glycogen synthase and eIF-2B, an enzyme critical for translation initiation by ribosomes (Singh et al., 1996; Dent et al., 1989).

Since GSK3 is involved in processes such as cell cycle arrest and inhibition of protein translation, and since wood frogs need to depress ATP-expensive processes such as cell division and protein synthesis for long term survival in the ischemic, frozen state, I hypothesized that GSK3 would be more active during freezing.

\section{Materials and Methods}

Animal experiments, preparation of tissue extracts and soluble protein determination and SDS polyacrylamide gel electrophoresis were as done in Chapter 2. 


\section{Sample preparation for protein kinase assays}

Frozen tissue samples were homogenized 1:5 w:v in cold $\left(4^{\circ} \mathrm{C}\right)$ buffer containing $50 \mathrm{mM}$ Tris-HCl, pH 7.4, $50 \mathrm{mM} \mathrm{NaF}, 4 \mathrm{mM}$ EDTA, $1 \mathrm{mM} \mathrm{Na}_{3} \mathrm{VO}_{4}$ and $0.1 \%(\mathrm{v} / \mathrm{v}) 2-$ mercaptoethanol. A few crystals of phenylmethylsulfonyl fluoride and $1 \mu \mathrm{L}$ (per ml of homogenization buffer) of Sigma Protease Inhibitor Cocktail were added immediately prior to homogenization. Homogenates were centrifuged $10,000 \mathrm{x} g$ for 25 minutes. The supernatant was removed and the concentration of protein was determined using the BioRad reagent as described above.

\section{Radioactive glycogen synthase kinase 3 assays}

GSK 3 activity was determined using a radioactive assay that measured the incorporation of radiolabeled $\gamma-{ }^{32} \mathrm{P}$ from $\gamma-{ }^{32} \mathrm{P}-\mathrm{ATP}(3000 \mathrm{Ci} / \mathrm{mmol}$; GE Healthcare Biosciences, Piscataway, NJ) onto a specific GSK3 peptide substrate. Assays were initiated by addition of $\gamma_{-}{ }^{32} \mathrm{P}-\mathrm{ATP}$ to the appropriate reaction mixture in $500 \mu \mathrm{L}$ Eppendorf tubes. The reaction volume was $25 \mu \mathrm{L}$ and the amount of crude extract used to assay GSK3 was optimized to contain $25 \mu \mathrm{g}$ of total soluble protein per assay. The GSK3 peptide substrate was obtained from Upstate (Millipore Corp. catalogue \# 12-241) and had the amino acid sequence: YRRAAVPPSPSLSRHSSPHQ( $\mathrm{pS})$ EDEEE (similar to the sequence around the phosphorylation site in human skeletal muscle glycogen synthase; $\mathrm{pS}$ is phosphorylated serine). Optimum assay conditions were $2 \mathrm{mM} \mathrm{MgCl}, 200 \mu \mathrm{M}$ $\mathrm{Mg}^{2+}$-ATP (containing $\left.0.5 \mu \mathrm{Ci} \gamma-{ }^{32} \mathrm{P}-\mathrm{ATP}\right), 0-75 \mu \mathrm{M}$ peptide $(20 \mu \mathrm{M}$ for the metabolic study) and assay buffer (50 mM Tris-HCl, pH 7.5, $1 \mathrm{mM} \mathrm{EGTA,} 0.15 \mathrm{M} \mathrm{NaCl}$ and $0.1 \%$ v/v 2-mercaptoethanol). The assay also contained $0.5 \mathrm{mM}$ of specific peptide inhibitors 
of protein kinases A and C (PKA fragment 5-24 and PKC fragment 19-31) (added as 1.25 $\mu \mathrm{L}$ from a $10 \mathrm{mM}$ stock). Zero substrate blanks were always run to account for nonspecific background signals. The reaction time was 30 minutes at $22^{\circ} \mathrm{C}$.

For a study of metabolite effects on GSK3 activity, the standard amount of peptide substrate used was $20 \mu \mathrm{M}$ and the metabolites to be tested were prepared in Tris buffer, $\mathrm{pH}$ 7.5. Metabolites were tested at the following concentrations: $5 \mathrm{mM}$ glucose-6phosphate (G6P), $10 \mathrm{mM}$ L-alanine, $10 \mathrm{mM}$ L-aspartate, $5 \mathrm{mM}$ succinate, $1 \mathrm{mM}$ AMP, 5 $\mathrm{mM}$ phosphoenolpyruvate (PEP), or $250 \mathrm{mM}$ D-glucose.

\section{Signal detection}

GSK3 activity was quantified based on concepts modified from Asensio and Garcia (2003). Reactions were stopped by addition of one-half reaction volume of $0.2 \mathrm{M}$ EDTA containing $0.1 \%(w: v)$ bromophenol blue. Aliquots of $2 \mu \mathrm{L}$ of the stopped reaction mix were then spotted onto penciled circles $(5 \mathrm{~mm}$ diameter) drawn in a grid on P81 paper. The P81 paper array was allowed to air dry under a fume hood followed by 4 quick washes in $0.8 \% \mathrm{v}: \mathrm{v}$ phosphoric acid, 2 long washes (10 minutes) with $0.8 \%$ phosphoric acid, and lastly 1 quick wash with $95 \%$ ethanol.

After washing, the paper array was allowed to air dry and was then placed under saran wrap and exposed to a storage phosphor screen in autoradiography cassettes. Prior to use, storage phosphor screens were stripped for at least 10 minutes using a white light

box. The exposure time for visualizing ${ }^{32} \mathrm{P}$-labeled GSK3 peptide was $1 \mathrm{~h}$. After exposure, phosphor screen signals were captured using a BioRad PhosphoImager (Hercules, CA). Quantification, background correction, and data analysis was performed 
using Quant One software, and relative signal density was transformed into units of activity using a standard curve of $\gamma^{32} \mathrm{P}$-ATP that was prepared using the same conditions as those for GSK3 activity (e.g. same spot volume, exposure time, etc.). One unit is defined as the amount of enzyme that phosphorylates $1 \mu \mathrm{mol}$ of peptide per minute. Kinetic parameters were determined using a nonlinear least squares regression computer program (Kinetics 3.51) (Brooks, 1992). Data are expressed as mean \pm S.E.M. with statistical testing performed using analysis of variance followed by the Student-NewmanKeuls test.

\section{Results}

GSK3 and phospho-GSK3 (ser9) were detected in all wood frog tissues tested: brain, heart, kidney, liver and skeletal muscle. The activity of GSK3 was also measured, using a radioactive assay, under various conditions: at $22^{\circ} \mathrm{C}$, at $4{ }^{\circ} \mathrm{C}$, and at both temperatures in the presence of $250 \mathrm{mM}$ glucose (a level mimicking the natural concentration of this cryoprotectant in vivo). The effects of other metabolites on GSK3 activity were also assessed at both high and low assay temperatures including: $5 \mathrm{mM}$ glucose-6-phosphate (G6P), $10 \mathrm{mM}$ L-alanine, $10 \mathrm{mM}$ L-aspartate, $5 \mathrm{mM}$ succinate, $1 \mathrm{mM}$ AMP, $5 \mathrm{mM}$ phosphoenolpyruvate (PEP), or $250 \mathrm{mM}$ D-glucose.

\section{GSK3 total protein levels}

Total GSK3 protein levels was quantified using Western blotting in wood frog tissues under three experimental conditions: control (acclimated at $5^{\circ} \mathrm{C}$ ), $24 \mathrm{~h}$ frozen (at $-2.5^{\circ} \mathrm{C}$ ) and $8 \mathrm{~h}$ thawed recovery (at $5^{\circ} \mathrm{C}$ ) after $24 \mathrm{~h}$ frozen (Figure 3.1). The GSK3 
antibody crossreacted with a single band at the expected molecular weight of $50 \mathrm{kDa}$. GSK3 protein was detected in all five tissues but protein levels did not change during freezing and thawing in brain, liver or muscle. In the heart, however, the GSK protein content decreased significantly $(\mathrm{P}<0.05)$ to $57.5 \%$ of control values when frogs were frozen, but returned to control levels when animals were thawed. In the kidney, GSK3 protein content did not change during freezing, but fell significantly $(\mathrm{P}<0.05)$ to $48.5 \%$ of the control value when the frogs were thawed.

\section{Phospho-GSK3 (ser9) levels}

GSK3 is inactivated by phosphorylation on serine residue 9 and Western blotting was also used to determine the relative amounts of the phosphorylated form of GSK3 (ser9) in control, frozen and thawed frogs (Figure 3.2). The phospho-GSK3 antibody crossreacted with a single band at the expected molecular weight of $50 \mathrm{kDa}$. PhosphoGSK3 (ser9) was again detected in all five tissues tested. The levels of phospho-GSK3 (ser9) decreased in all organs during freezing and remained suppressed after $8 \mathrm{~h}$ thawing in three tissues. In brain, phospho-GSK3 content decreased significantly $(\mathrm{P}<0.05)$ to $50.7 \%$ of the control value during freezing and remained low at $44.9 \%$ of control levels after $8 \mathrm{~h}$ thawing. A similar pattern was seen in muscle tissues, with phospho-GSK3 levels that were $27.3 \%$ and $38.6 \%$ in heart and 15.0 and $26.5 \%$ in skeletal muscle of frozen and thawed frogs, respectively, as compared with controls $(\mathrm{P}<0.05)$. In the kidney and liver, however, phospho-GSK3 content decreased significantly $(\mathrm{P}<0.05)$ during freezing (to $50.0 \%$ in kidney and $43.1 \%$ in liver of controls) but rebounded again when frogs thawed to $\sim 89 \%$ of the control value in each case. 


\section{GSK enzyme activities}

GSK3 activity was measured in extracts of skeletal muscle of control wood frogs (acclimated at $5^{\circ} \mathrm{C}$ ) and animals frozen for $24 \mathrm{~h}$ at $-2.5^{\circ} \mathrm{C}$. A specific peptide substrate was used which mimics the phosphorylation site on skeletal muscle glycogen synthase. Velocity versus peptide concentration curves were generated under four different conditions: at high $\left(22^{\circ} \mathrm{C}\right)$ and low $\left(4^{\circ} \mathrm{C}\right)$ temperatures (Figures 3.3 and 3.4$)$ and in the presence of $250 \mathrm{mM}$ glucose at each temperature (Figures 3.5 and 3.6). $\mathrm{V}_{\max }, \mathrm{K}_{\mathrm{m}}$, and Hill coefficient $\left(\mathrm{n}_{H}\right)$ values were calculated using a kinetics program (Brooks, 1992) with the data from the velocity vs substrate concentration curves. The values for four independent trials using different preparations of enzyme are summarized in Table 3.1.

The velocity versus [peptide] curve at $22^{\circ} \mathrm{C}$ was near hyperbolic for frog muscle GSK3 (Fig. 3.3) with $n_{H}$ values that were close to 1.0. Enzyme affinity for peptide did not change between control $\left(5^{\circ} \mathrm{C}\right.$ acclimated $)$ and frozen $\left(-2.5^{\circ} \mathrm{C}\right)$ situations, being $23.5 \pm 4.2$ $\mu \mathrm{M}$ and $33.1 \pm 4.4 \mu \mathrm{M}$ for GSK3 from control and frozen frogs, respectively. $\mathrm{V}_{\max }$ values were calculated (from the computer analysis of the velocity vs substrate concentration curves using the kinetics program) to be $1.83 \pm 0.30$ units $/ \mathrm{mg}$ for control and $2.27 \pm 0.18$ units/mg soluble protein for frozen frogs, both assayed at $22^{\circ} \mathrm{C}$. When the enzyme was assayed at $4^{\circ} \mathrm{C}, \mathrm{V}_{\max }$ was strongly reduced as is expected for the effects of temperature on enzyme reactions. The $\mathrm{K}_{\mathrm{m}}$ value for GSK3 from control muscle did not change significantly when assayed at $4^{\circ} \mathrm{C}$ but the $K_{m}$ for the enzyme from frozen frogs was reduced by $50 \%$ as compared to the $22^{\circ} \mathrm{C}$ assay $(\mathrm{P}<0.05)$. The Hill coefficient values were unchanged for the frozen enzyme but increased for the control enzyme assayed at 
$4^{\circ} \mathrm{C}$. Glucose is the natural cryoprotectant in wood frogs and rises to high levels in frog organs during freezing. To determine if glucose affected GSK3 activity, assays at 22 and $4^{\circ} \mathrm{C}$ were repeated in the presence of $250 \mathrm{mM}$ glucose. The addition of glucose significantly changed both $V_{\max }$ and $\mathrm{K}_{\mathrm{m}}$ of the enzyme from both $5^{\circ} \mathrm{C}$ acclimated and $-2.5^{\circ} \mathrm{C}$ frozen frogs in $22^{\circ} \mathrm{C}$ assays. For the enzyme from control frogs, both $\mathrm{K}_{\mathrm{m}}$ and $\mathrm{V}_{\max }$ increased significantly; for example, $\mathrm{K}_{\mathrm{m}}$ increased by $73 \%$. On the other hand, the properties of the enzyme from frozen frogs were opposite with $\mathrm{K}_{\mathrm{m}}$ decreasing by $34 \%$ and $V_{\max }$ by $50 \%$ as compared to the values in assays without glucose. When GSK3 was assayed at $4^{\circ} \mathrm{C}$ in the presence of $250 \mathrm{mM}$ glucose, the sigmoidicity of the reaction increased substantially (Figure 3.6) with Hill coefficients that rose to 2.6-2.8 for the enzyme from both control and frozen frogs (Table 3.1). $\mathrm{V}_{\max }$ values were also reduced as compared with the enzyme assayed at $4^{\circ} \mathrm{C}$ without glucose. The $\mathrm{K}_{\mathrm{m}}$ value for the enzyme from control frogs was the same as the value for $4^{\circ} \mathrm{C}$ assays in the absence of glucose but for the enzyme from frozen animals, the $\mathrm{K}_{\mathrm{m}}$ was significantly higher than the value in the absence of glucose (about 2-fold, $\mathrm{P}<0.05$ ) and equivalent to the value determined in $22^{\circ} \mathrm{C}$ assays without glucose.

\section{Metabolic study of GSK3 effectors}

The effects of different metabolites on GSK3 activity was assessed at a constant peptide substrate concentration of $20 \mu \mathrm{M}$ at $22^{\circ} \mathrm{C}$ (Figure 3.7) and at $4^{\circ} \mathrm{C}$ (Figure 3.8). Seven metabolites that were predicted to change in vivo in muscle during freezing were tested at levels that are at the high end of the normal range of these metabolites in frog organs: $5 \mathrm{mM} \mathrm{G6P,} 10 \mathrm{mM}$ alanine, $10 \mathrm{mM}$ aspartate, $5 \mathrm{mM}$ succinate, $1 \mathrm{mM}$ AMP, 5 
$\mathrm{mM}$ PEP, $250 \mathrm{mM}$ glucose. Activities are reported as the percentage of the activity obtained in the absence of added metabolites.

\section{Analysis at $22^{\circ} \mathrm{C}$}

When the activity of GSK3 was assessed at $22^{\circ} \mathrm{C}$, several metabolites had no significant effect on enzyme activity, either when compared with assays run without added metabolites or in assays comparing activities of GSK3 in extracts from control $\left(5^{\circ} \mathrm{C}\right.$ acclimated) versus frozen frogs (Figure 3.7). These included $10 \mathrm{mM}$ alanine, 10 $\mathrm{mM}$ aspartate, $5 \mathrm{mM}$ succinate and $5 \mathrm{mM}$ PEP. When $5 \mathrm{mM}$ G6P was present, significant increases in activity were seen for the enzyme from both $5^{\circ} \mathrm{C}$ acclimated and frozen frogs (by 1.32 and 1.84 fold, respectively) $(\mathrm{P}<0.05)$. Furthermore, the effect was significantly greater for the enzyme from frozen frogs. By contrast both $1 \mathrm{mM}$ AMP and $250 \mathrm{mM}$ glucose significantly reduced the activity of GSK3 from muscle of control $5^{\circ} \mathrm{C}$ acclimated frogs by $33.6 \%$ and $7.1 \%(\mathrm{P}<0.05)$, respectively. However, these metabolites did not affect enzyme activity in muscle from frozen frogs.

\section{Analysis at $4^{\circ} \mathrm{C}$}

When the same assays were conducted at $4^{\circ} \mathrm{C}$, activity of GSK3 was again unaffected by the addition of $10 \mathrm{mM}$ alanine, $10 \mathrm{mM}$ aspartate or $5 \mathrm{mM}$ succinate. G6P again activated the enzyme from frozen muscle (by 1.18 - fold, $\mathrm{P}<0.05$ ), an effect that was less than that seen at $22^{\circ} \mathrm{C}$, but the control enzyme was not affected by G6P in the cold. By contrast, $1 \mathrm{mM}$ AMP was a stronger effector at $4^{\circ} \mathrm{C}$, decreasing activity by $61.1 \%$ and $36.2 \%$ for the enzyme from control and frozen frogs, respectively. Glucose at $250 \mathrm{mM}$ glucose was also a stronger inhibitor in $4^{\circ} \mathrm{C}$ assays, reducing activities significantly by $21.6 \%$ and $19.2 \%(P<0.05)$ for the enzyme from control and frozen frogs, respectively. In 
addition, $5 \mathrm{mM}$ PEP had a small inhibitory effect (a $13.1 \%$ decrease, $\mathrm{P}<0.05$ ) on GSK3 activity from control muscle but did not affect the enzyme from frozen muscle.

\section{Discussion}

In 1980, glycogen synthase kinase 3 (GSK3) was identified as one of protein kinases that phosphorylates glycogen synthase, the enzyme that catalyses the last step in glycogen synthesis (Embi et al., 1980). The phosphorylation of glycogen synthase by GSK3 inactivates the enzyme. Protein kinase B (also known as Akt) was later shown to be responsible for controlling the insulin-induced inhibition of GSK3 by catalyzing the phosphorylation of a serine residue in the amino acid terminus of GSK3 (Cross et al., 1995). When GSK3 activity is inhibited, its substrates such as glycogen synthase and the eukaryotic initiation factor 2B (eIF2B) can be dephosphorylated (and therefore activated) by protein phosphatases, assisting the insulin-induced activation of both glycogen synthesis and protein synthesis (Parker et al., 1983; Hughes et al., 1992). GSK3 is unique among protein kinases since it requires that many of its substrates are first phosphorylated by another protein kinase on a serine or threonine residue (termed the priming substrate) situated four residues carboxy-terminal to the site of GSK3 phosphorylation (Fiol et al., 1987). When the serine residue near the amino terminus of

GSK3 becomes phosphorylated, it interacts with the same residues that are involved in binding the priming phosphate (in the active site) and so phosphorylation suppresses activity by turning the amino terminus of GSK3 into a simulated substrate. This not only prevents substrates from binding, but also blocks access to the catalytic center, thereby shutting down GSK3 activity (Frame et al., 2001). 
The same residue on GSK3 that is targeted by PKB/Akt is also known to be phosphorylated by other protein kinases in response to different signals. For example, growth factors can inhibit GSK3 activity through the classical MAPK cascade, as well as by the PtdIns $(3,4,5) \mathrm{P}_{3}$-dependent pathway (Stambolic and Woodgett, 1994; Shaw and Cohen, 1999). Amino acids can also reduce GSK3 activity through a pathway that involves the mammalian target of rapamycin (mTOR) (Armstrong et al., 2001). The phosphorylation of GSK3 can additionally be catalyzed by cyclic-AMP-dependent protein kinase (PKA) in response to agonists that elevate the intracellular concentration of cAMP (Fang et al., 2000; Li et al., 2000). GSK3 also has other downstream targets than those mentioned above (glycogen synthase and eIF2B); these include cyclin D1 and the transcription factor c-myc. Phosphorylation of these proteins targets them for ubiquitylation and subsequent proteolytic destruction. Cyclin D1 facilitates entry into the $\mathrm{S}$ phase of cell-division while c-myc stimulates cell proliferation. GSK3 also phosphorylates several residues in the transcription factor c-jun, suppressing its binding to DNA and thereby inhibiting the transcription of several c-jun regulated genes, including cyclin D1 (Sabbah et al., 1999). Therefore, GSK3 exerts negative controls a number of key downstream targets that regulate in biosynthesis, cell cycle and growth processes.

\section{GSK3 Protein Levels}

In the current study, the levels of GSK3 and a phosphorylated form of GSK3 (at serine position 9) were assessed in control (acclimated at $5^{\circ} \mathrm{C}$ ), $24 \mathrm{~h}$ frozen (at $-2.5^{\circ} \mathrm{C}$ ) and $8 \mathrm{~h}$ thawed (at $5^{\circ} \mathrm{C}$ ) wood frogs in 5 tissues (brain, heart, kidney, liver, muscle). The 
protein was detected in all tissues tested. Total GSK3 protein levels did not change significantly in the brain, liver and muscle during freezing and thawing (Figure 3.1). Since this antibody does not distinguish between the unphosphorylated and phosphorylated forms of GSK3, it represents the total amount of GSK3 present in the tissues during control, frozen and thawed conditions. However, total GSK3 protein levels did decrease significantly during freezing in heart, and then increased again to near control levels during thawing. In the kidney, the total amount of GSK3 did not change significantly during freezing, but did decrease significantly when frogs were thawed for 8 hours. Overall, therefore, total GSK3 protein is maintained at fairly constant levels over cycles of freeze/thaw which has two implications: (a) the enzyme is always present to respond when needed, and (b) the regulation of the activity of this kinase probably comes mainly from posttranslational controls.

Indeed, the levels of phosphorylated GSK3 (Ser 9) were significantly reduced in all tissues of frozen frogs, as compared with controls, and remained low after $8 \mathrm{~h}$ thawed in brain, heart and skeletal muscle (Figure 3.2). Since GSK3 is inactivated by phosphorylation, the phosphorylated form represents the relative amount of inactive GSK3 present in the tissues. The amount of active GSK 3 would have the opposite pattern therefore. Since the total amount of GSK3 did not change significantly in four tissues during freezing, and since the phosphorylated (inactive) form of the enzyme decreased significantly during freezing, this implies that the amount of active GSK3 strongly increases during freezing in liver, kidney, muscle and brain. In heart, the situation is a little harder to evaluate but the decrease in total GSK3 protein was $\sim 42 \%$ whereas phospho-GSK3 content was more strongly reduced by $73 \%$. Overall, then, this would be 
consistent with a higher relative amount of dephosphorylated active GSK3 in heart of frozen frogs. In the liver and kidney, the relative amount of phosphorylated GSK3 rose again to near control levels after thawing. A rapid reversal is key in liver which has to begin clearing the massive load of glucose that was produced as a cryoprotectant and restore it as liver glycogen. Skeletal muscle showed a small increase in phosphoenzyme content during thawing but did not return to control levels whereas there was no change in phospho-GSK3 amount in brain and heart after $8 \mathrm{~h}$ of thawing (although these tissues might just require longer recovery times). In heart, however, the rise in total GSK3 protein during thawing, when coupled with sustained low phospho-GSK3, would indicate an active GSK3 protein in thawed heart.

The freeze/thaw changes in GSK3 in frog organs can be interpreted with respect to what is already known about glycogen metabolism during freezing in wood frogs. Freezing triggers a rapid increase in glycogen phosphorylase (GP) activity, particularly in liver, that initiated glycogen breakdown and a strong increase in glucose within minutes (Storey and Storey, 1988). The production and export of glucose as a cryoprotectant continues over several hours until all organs have high glucose levels; in core organs glucose rise to $150-300 \mathrm{mM}$ compared with about $5 \mathrm{mM}$ in control frogs. GP is activated as a result of adrenergic signals that elevate cyclic AMP and activate PKA (Figure 3.9). When GP is active and breaking down glycogen, it is important that GS is turned off to prevent a wasteful ATP-dependent recycling of glucose into glycogen. Indeed, measurement of GS activity showed that it was reduced to very low levels during freezing following an inverse pattern to that seen for GP activity (Russell and Storey, 1995). Since GSK3 inhibits GS, the key regulatory enzyme in the glycogen synthesis 
pathway, then a more active GSK3 during freezing would be consistent with the inactivation of GS that is needed during freezing.

GSK3 is also known to inhibit other key proteins such as c-myc, a transcription factor involved in cell growth, cyclin D1, a protein needed for cell differentiation, and eIF-2B, an enzyme that is critical for translation initiation. Cell growth, cell differentiation and translation are all suppressed during freezing, as part of the metabolic rate depression experienced by the wood frog, and so the increase in active GSK3 during freezing, observed from Western blotting, is consistent with GSK3-mediated inhibition of these processes (Storey and Storey, 2004a). Active GSK3 would turn off all these processes in the frozen frog. During thawing, however, these cell functions should be reactivated and, indeed, after just $8 \mathrm{~h}$ back at $5^{\circ} \mathrm{C}$ (typically it takes up to $4 \mathrm{~h}$ for all body ice to melt at this temperature; J. Storey, unpublished results) the amount of phosphorylated inactive GSK3 had risen back to control levels in liver and kidney. The sustained low levels of phospho-GSK3 in the other tissues after $8 \mathrm{~h}$ may simply reflect a slower recovery of metabolic processes in these tissues. The rise in inactive phosphoGSK3 content back to control levels within $8 \mathrm{~h}$ in liver would allow the reactivation of GS and the reconversion of cryoprotectant back into glycogen stores in liver. Although it takes many days to reduce glucose levels back to normal (Storey and Storey, 2004b), the process gets underway quite quickly. Thus, frogs thawed for $24 \mathrm{~h}$ at $5^{\circ} \mathrm{C}$ showed high GS activity so glycogen resynthesis seems to be well established by that time. Russell and Storey (1995) found that the percentage of GS in the active form in wood frog liver was $81.5 \%$ in $24 \mathrm{~h}$ thawed frogs compared with a control level of $34 \%$ and a level in liver of $24 \mathrm{~h}$ frozen frogs of just $11 \%$. 


\section{GSK3 enzyme properties}

GSK3 activity was determined in Rana sylvatica muscle extracts at varying peptide concentrations (from 0-75 $\mu \mathrm{M}$ ) for control (acclimated at $5^{\circ} \mathrm{C}$ ) and frozen ( $8 \mathrm{~h}$ at $-2.5^{\circ} \mathrm{C}$ ) conditions. Assays were conducted at $22^{\circ} \mathrm{C}$ (Figure 3.3) and $4^{\circ} \mathrm{C}$ (Figure 3.4) and in the absence versus presence of $250 \mathrm{mM}$ glucose (Figure 3.5, 3.6). Assays in the presence of high glucose were used to determine if the frog cryoprotectant that is accumulated during freezing affected the kinetics of frog GSK3. $V_{\max }, \mathrm{K}_{\mathrm{m}}$ and Hill coefficients were determined for each condition (Table 3.1). The Hill coefficients were greater than one in all cases, which indicates a positive cooperation reaction; once one ligand molecule is bound to the enzyme, its affinity for other ligand molecules increases. This positive cooperation reaction typically occurs with proteins that have multiple subunits, and so this result makes sense since GSK3 is a dimer. However, the Hill coefficients between control and frozen conditions were not significantly different in any of the conditions assayed. The GSK3 enzyme velocity determined at room temperature for control and frozen frog muscle did not differ and there was no significant difference found between the $\mathrm{K}_{\mathrm{m}}$ and $\mathrm{V}_{\max }$ between control and frozen tissues. For control and frozen muscle, when the assay was performed at $4^{\circ} \mathrm{C}$, the $V_{\text {max }}$ was not significantly different, but there was a significant difference $(\mathrm{P}<0.05)$ between the $\mathrm{K}_{\mathrm{m}}$ for control $(29.7 \pm 2.6 \mu \mathrm{M})$ and frozen $(16.6 \pm 0.7 \mu \mathrm{M})$. The $K_{m}$ value for the enzyme from frozen tissue was lower, which indicates that GSK3 from frozen tissue has a higher affinity for its peptide when assayed at $4^{\circ} \mathrm{C}$, which could result from a modification to the frozen enzyme. A significant difference was also seen between the $\mathrm{K}_{\mathrm{m}}$ of the frozen enzyme at $4{ }^{\circ} \mathrm{C}$ and at $22^{\circ} \mathrm{C}(\mathrm{a} 50 \%$ 
decrease), which could also be due to the frozen enzyme being modified to have a higher affinity for its substrate. When $250 \mathrm{mM}$ glucose was included in the assay, and the assay was performed at room temperature, a significant difference in $K_{m}$ was seen between GSK3 from control $(40.6 \pm 4.0 \mu \mathrm{M})$ and frozen $(21.8 \pm 2.9 \mu \mathrm{M})$ muscle and since the $\mathrm{K}_{\mathrm{m}}$ value was lower for the enzyme from frozen tissue, this indicates that GSK3 in the frozen state has a higher affinity for its peptide substrate. GSK3 $V_{\max }$ in extracts from frozen muscle assayed at $22^{\circ} \mathrm{C}$ with $250 \mathrm{mM}$ glucose was found to be significantly lower $(\mathrm{P}<0.05)$ at $1.14 \pm 0.35$ units $/ \mathrm{mg}$ compared to the control value of $2.89 \pm 0.64 \mathrm{units} / \mathrm{mg}$. The lower $V_{\max }$ found in frozen tissue implies that the enzyme is less active at room temperature with $250 \mathrm{mM}$ glucose. When the activity of GSK3 was assayed at $4^{\circ} \mathrm{C}$ and the assay contained $250 \mathrm{mM}$ glucose, there was no significant difference between the $\mathrm{K}_{\mathrm{m}}$ and $V_{\max }$ values between control and frozen tissues. Generally, GSK3 is much less active when assayed at $4^{\circ} \mathrm{C}$, indicated by the lower $V_{\max }$ observed compared to the assays performed at room temperature. This lower activity at low temperatures is the expected temperature effect on any reaction rate. Enzyme rates typically decrease by $\sim 2$-fold for a $10^{\circ} \mathrm{C}$ decrease in temperature, which was seen for the control enzyme without glucose and the frozen enzyme with and without glucose (a 3-4-fold decrease). A much higher decrease in enzyme rate (9.6-fold) was seen for the control enzyme with glucose, which could be due to a glucose-induced enzyme modification in the control state. It also seems as if GSK3 from frozen muscle could have a higher affinity for the peptide compared to the control. An enzyme that binds its substrate more effectively could be advantageous when it is crucial to quickly turn off pathways in order to conserve energy to survive. 
When the effect of glucose on the enzyme is analyzed at $22^{\circ} \mathrm{C}$, an opposing effect is observed for the $\mathrm{K}_{\mathrm{m}}$ and $\mathrm{V}_{\max }$ values for the control and frozen enzymes. For the control enzyme, the $K_{m}$ and $V_{\max }$ values significantly increase in the presence of glucose, while for the frozen enzyme, the values significantly decrease. This result implies that GSK3 in the control frog has a lower affinity and a higher maximum activity in the presence of glucose, while in the frozen frog, the enzyme has a higher affinity for the substrate and has a lower maximum activity in the presence of glucose. The higher affinity and lower maximum activity implies that the enzyme is more efficient in the frozen state and could be beneficial to the frog since it allows the enzyme to remain active when its metabolic rate is depressed. At $4^{\circ} \mathrm{C}$, the $\mathrm{K}_{\mathrm{m}}$ of the frozen enzyme with glucose was significantly higher when compared to the enzyme without glucose, but was similar to the frozen enzyme at $22^{\circ} \mathrm{C}$ without glucose. This result implies that, at $4^{\circ} \mathrm{C}$, GSK3 from frozen tissue is less active in the presence of glucose.

\section{Metabolite study}

The velocity of GSK3 with $20 \mu \mathrm{M}$ of peptide was measured in the presence of several metabolites (5 mM G6P, $10 \mathrm{mM}$ alanine, $10 \mathrm{mM}$ aspartate, $5 \mathrm{mM}$ succinate, 1 $\mathrm{mM}$ AMP, $5 \mathrm{mM}$ PEP, $250 \mathrm{mM}$ glucose) to determine if any of these could be allosteric effectors of the enzyme. Glucose-6-phosphate (G6P) is at the start of glycolysis and the pentose phosphate pathways and can also be converted to glycogen for storage or to glucose for export. It was found to be present at concentrations of $\sim 0.3 \mathrm{mM}$ in control liver tissue wood frogs and rose to $\sim 0.9 \mathrm{mM}$ in frozen liver during active glucose synthesis for cryoprotection (Storey, 1987b). G6P is also an important metabolite 
regulator of GS, causing the allosteric activation of the enzyme (via a conformational rearrangement) that also converts GS into a better substrate for protein phosphatases, which can dephosphorylate GS to activate it (Ferrer et al., 2003). Hence, in most vertebrates, high G6P is typically a signal that sugar availability is high and that glycogen synthesis should be activated. Alanine and aspartate are amino acids, whereas succinate is in intermediate of the tricarboxylic acid cycle (energy-producing); in many anoxia tolerant species, alanine and succinate are additional products of anaerobic carbohydrate catabolism (in addition to or instead of L-lactate) whereas aspartate is an anaerobic substrate. In wood frog control muscle, alanine and aspartate are present at approximately $5 \mathrm{mM}$ and $2 \mathrm{mM}$ while in the frozen tissue, they are present at concentrations of $10-15$ $\mathrm{mM}$ and $1 \mathrm{mM}$, respectively (Storey and Storey, 1985). Alanine accumulates along with lactate as a product of glycolysis in the anoxic and ischemic tissues of frozen frogs (Storey and Storey, 1985). Phosphoenolpyruvate (PEP) is a late intermediate in glycolysis and its production by the enzyme PEP carboxykinase is the rate-limiting step of gluconeogenesis, the pathway by which excess carbohydrates and amino acids can be converted back to glucose. Adenosine monophosphate (AMP) is one of the three adenylates (ATP, ADP, AMP) that make up the primary energy currency of cells. The concentration of PEP did not change significantly at $\sim 0.05 \mathrm{mM}$ between control and frozen wood frog liver, whereas AMP in control and frozen muscle was about $0.02 \mathrm{mM}$ and $0.05 \mathrm{mM}$, respectively (Storey, 1987). AMP accumulates in tissues under energy stress, including during anoxia and freezing. It is an allosteric activator of various enzymes involved in pathways of ATP production, and stimulates the AMP-dependent protein kinase which in turn also regulates a variety of enzymes of energy metabolism. 
Glucose is an energy source and in the wood frog, a cryoprotectant. It is found at concentrations of about $5 \mathrm{mM}$ in control muscle and in the $150-300 \mathrm{mM}$ range in the tissues of frozen frogs. GSK3 activity was determined in extracts from control (acclimated at $5^{\circ} \mathrm{C}$ ) and frozen $\left(24 \mathrm{~h}\right.$ at $\left.-2.5^{\circ} \mathrm{C}\right)$ muscle in the presence versus absence of the various metabolites and their effects are shown in shown in Figure 3.7 (for assays at $22^{\circ} \mathrm{C}$ ) and Figure 3.8 (for assays at $4^{\circ} \mathrm{C}$ ).

\section{Analysis at $22^{\circ} \mathrm{C}$}

When assayed at room temperature, the velocity of GSK3 at $20 \mu \mathrm{M}$ peptide did not change significantly between control and frozen tissues and also when assayed with and without selected metabolites: $10 \mathrm{mM}$ alanine, $10 \mathrm{mM}$ aspartate, $5 \mathrm{mM}$ succinate and 5 mM PEP. Glucose had a small effect on the control enzyme but G6P and AMP showed substantial regulatory effects. G6P at $5 \mathrm{mM}$ significantly increased GSK3 velocity by $33 \%$ and $84 \%$ for the enzyme from control and frozen muscle, respectively $(\mathrm{P}<0.05)$, whereas $1 \mathrm{mM}$ AMP produced an inhibition of activity by about $34 \%$ for the control enzyme. To our knowledge, this may be the first report of metabolite effectors changing the activity of the active form of GSK3. When frogs start to freeze, glycogen phosphorylase (GP) is rapidly activated and G6P levels quickly rise and are converted into glucose which accumulates in high levels inside cells and is also exported by the liver to other organs (Storey and Storey, 1988). However, G6P can also be reconverted to glycogen, a process that that would be futile for producing cryoprotectant. An activation of GSK3 by G6P could enhance its ability to phosphorylate and inhibit GS and prevent glycogen resynthesis while the frog is freezing. This would help to keep all glucose as a 
cryoprotectant. The effect of G6P was also stronger with GSK3 from frozen frogs versus controls which might also argue for a stable modification of GSK3 during freezing that makes it more susceptible to G6P allosteric activation. When the frogs thaw, G6P levels fall rapidly (Storey, 1987b) and this would remove the activating effect and might make GSK3 more susceptible to inactivation by phosphorylation. The increase in GSK3 velocity in the control tissue was unexpected since glycogen synthesis would be expected to be occurring in active wood frogs to store G6P when it is present at an increased level, and consequently, GSK3 should be less active when frogs are in a control state in the presence of G6P compared to when G6P is not added. A possible explanation to this unexpected result is that there is less active enzyme in the control muscle, and so such a high concentration of G6P (much higher than physiological levels) should have some sort of effect on the portion of active GSK3. Another explanation is that the addition of sufficient G6P was found to be able to overcome the inactivating effects of phosphorylation and restore nearly full activity to the phosphorylated glycogen synthase enzyme in mammalian muscle tissue (Wilson et al., 2005). And so, in the control state, GSK3 is more active when $5 \mathrm{mM}$ G6P is present, but glycogen synthase enzyme inhibition is overridden by the high G6P concentration, enabling glycogen synthesis to occur.

By contrast when $1 \mathrm{mM}$ AMP was included in the assay, the velocity of GSK3 was significantly reduced $(\mathrm{P}<0.05)$ for the control enzyme. Activity was reduced by about $34 \%$. When AMP levels rise, cells are running out of energy and often this is due to conditions such as hypoxia/ischemia or high rates of muscle work that compromise the ability to produce ATP by oxidative metabolism in the mitochondria alone. High AMP is 
typically a signal that glycogenolysis needs to be activated to increase flux through glycolysis. Furthermore, it is necessary to conserve ATP as much as possible and energyexpensive pathways are shut down. This includes many biosynthetic processes, several of which are regulated by GSK3. Thus, GSK3 inhibits not just glycogen synthesis but also protein synthesis by inhibiting eIF-2B, a critical protein for translation initiation by ribosomes. Also, by inhibiting glycogen synthesis, available glucose can be metabolized by glycolysis when needed to fuel ATP production. AMP is a known activator of glycogen breakdown via GP. Although 1mM AMP appears to significantly inhibit GSK3 in vitro, this concentration is $50-100$ fold higher than physiological concentrations, which means that this observed effect probably has no role in regulating the enzyme in vivo. It does imply that adenylates have an effect on the enzyme.

\section{Analysis at $4^{\circ} \mathrm{C}$}

The velocity of GSK3 did not change significantly for extracts of control of frozen frog muscle when $10 \mathrm{mM}$ alanine, $10 \mathrm{mM}$ aspartate or $5 \mathrm{mM}$ succinate were included in the assay performed at $4^{\circ} \mathrm{C}$. GSK3 was slightly inhibited by PEP and glucose at $4^{\circ} \mathrm{C}$ but the major effectors were again G6P and AMP. GSK3 velocity was significantly higher (by $18 \%, \mathrm{P}<0.05$ ) in the presence versus absence of $5 \mathrm{mM} \mathrm{G6P}$ for the enzyme from frozen tissue but G6P did not affect the control enzyme when assayed at $4^{\circ} \mathrm{C}$. Again, this effect of G6P would help to inhibit glycogen resynthesis under cold or frozen conditions when glycogen breakdown needs to be directed into the synthesis of glucose as the cryoprotectant. AMP also inhibited GSK3 activity at low temperature and here the effects were greater than seen at $22^{\circ} \mathrm{C}$ and the effect on the control enzyme was substantially 
greater with activity reduced by about $60 \%$ as compared with the frozen enzyme where AMP inhibited by only about $38 \%$.

\section{Conclusion}

In the current study, the levels of GSK3 and a phosphorylated form of GSK3 (ser 9) were assessed in control (acclimated at $5^{\circ} \mathrm{C}$ ), $24 \mathrm{~h}$ frozen $\left(\right.$ at $-2.5^{\circ} \mathrm{C}$ ) and $8 \mathrm{~h}$ thawed (at $5^{\circ} \mathrm{C}$ ) wood frogs in 5 tissues (brain, heart, kidney, liver, muscle). Total protein levels of GSK3 did not change during freezing and thawing in the brain, liver and muscle. They did decrease significantly during freezing in the wood frog heart, and then increased to near control levels. In the kidney, the total amount of GSK3 protein decreased significantly when thawed for 8 hours.

The levels of phosphorylated GSK3 were significantly lower in all tissues from frozen frogs. This implies that there is more active enzyme present when tissues freeze. Phosphorylated GSK3 levels remained low after $8 \mathrm{~h}$ of thawing in brain and heart, but increased somewhat in skeletal muscle and rebounded completely to control levels in liver and kidney. The rapid reversal in liver, in particular, may be closely related to the need to begin to clear the high glucose cryoprotectant levels and restore the carbon as glucose. High levels of phosphorylated inactive GSK3 would allow GS to be dephosphorylated and activated by protein phosphatases.

When looking at the temperature effects on the $V_{\max }$ values of the GSK3 enzyme, an expected drop of 3-4-fold is seen in the control enzyme without glucose and the frozen enzyme with and without glucose, when this enzyme is assayed at $4^{\circ} \mathrm{C}$ compared to $22^{\circ} \mathrm{C}$. An unexpected 10 -fold decrease in $\mathrm{V}_{\max }$ for the control GSK3 enzyme with 250 
$\mathrm{mM}$ glucose could be due to a glucose-induced enzyme modification in the control state which lowers the maximum velocity of the enzyme. When comparing the frozen enzyme assayed at $22^{\circ} \mathrm{C}$ and $4^{\circ} \mathrm{C}$, the $\mathrm{K}_{\mathrm{m}}$ dropped by $50 \%$ when assayed at $4^{\circ} \mathrm{C}$, implying that the frozen enzyme could be modified to have a higher affinity for its substrate. The addition of glucose lowers enzyme activity and increases maximum velocity of control GSK3 enzyme while having the opposite effect on the frozen enzyme. Glucose seems to have somewhat of an inhibitory effect on the control enzyme, but increases the specificity of the frozen enzyme. When the affinity of GSK3 for its peptide is compared in control and frozen tissue at $4^{\circ} \mathrm{C}$ without glucose, the frozen enzyme has a significantly higher affinity, implying that the enzyme in the frozen tissue is more efficient than that in the control tissue.

Aspartate, alanine and succinate were not allosteric modifiers of GSK3. G6P was found to have an activating effect on the enzyme, whereas AMP suppressed enzyme activity. PEP and glucose also had slight inhibitory effects on GSK3. To our knowledge, this may be the first report of metabolite effectors changing the activity of the active form of GSK3. 


\section{Table 3.1}

Summary of kinetic data for GSK3 for four different assay conditions: at high $\left(22^{\circ} \mathrm{C}\right)$ and low $\left(4^{\circ} \mathrm{C}\right)$ temperatures and in the absence versus presence of $250 \mathrm{mM}$ glucose at each temperature. $V_{\max }, K_{m}$, and Hill coefficient $\left(n_{H}\right)$ values were obtained from the computer analysis of the velocity vs substrate concentration curves, using a Kinetics program. Statistical testing used analysis of variance followed by the Student-NewmanKeuls test. Data are means \pm SEM, $n=4$ determinations on separate extracts of control and frozen muscle.

\begin{tabular}{|l|l|l|l|}
\cline { 2 - 4 } \multicolumn{1}{c|}{} & $\mathrm{K}_{\mathrm{m}}(\mu \mathrm{M})$ & $\mathrm{V}_{\max }(\mathrm{U} / \mathrm{mg})$ & Hill coefficient \\
\hline Control, $5^{\circ} \mathrm{C}$ acclimated & & & \\
\hline $22^{\circ} \mathrm{C}$ & $23.5 \pm 4.2$ & $1.83 \pm 0.30$ & $1.34 \pm 0.13$ \\
$4^{\circ} \mathrm{C}$ & $29.7 \pm 2.6$ & $0.60 \pm 0.02 \mathrm{~b}$ & $1.93 \pm 0.55$ \\
$22^{\circ} \mathrm{C}+250 \mathrm{mM}$ glucose & $40.6 \pm 4.0 \mathrm{c}$ & $2.89 \pm 0.64 \mathrm{C}$ & $1.46 \pm 0.11$ \\
$4^{\circ} \mathrm{C}+250 \mathrm{mM}$ glucose & $30.1 \pm 2.2$ & $0.30 \pm 0.04 \mathrm{~b}$ & $2.80 \pm 0.38$ \\
\hline \multicolumn{3}{|l}{} \\
\hline Frozen, $-2.5^{\circ} \mathrm{C}(24$ hours $)$ & \multicolumn{3}{|l}{} \\
\hline $22^{\circ} \mathrm{C}$ & $33.1 \pm 4.4$ & $2.27 \pm 0.18$ & $1.53 \pm 0.20$ \\
$4^{\circ} \mathrm{C}$ & $16.6 \pm 0.7 \mathrm{a}, \mathrm{b}$ & $0.59 \pm 0.08 \mathrm{~b}$ & $1.34 \pm 0.18$ \\
$22^{\circ} \mathrm{C}+250 \mathrm{mM}$ glucose & $21.8 \pm 2.9 \mathrm{a}, \mathrm{C}$ & $1.14 \pm 0.35 \mathrm{a}, \mathrm{C}$ & $2.09 \pm 0.26$ \\
$4^{\circ} \mathrm{C}+250 \mathrm{mM}$ glucose & $33.2 \pm 4.5 \mathrm{C}$ & $0.41 \pm 0.04$ & $2.56 \pm 0.80$ \\
\hline
\end{tabular}

$a=$ significantly different $(P<0.05)$ from the corresponding value from control frogs at the same temperature and glucose concentration

$b=$ significantly different $(P<0.05)$ from the corresponding value at $22^{\circ} \mathrm{C}$ at the same glucose concentration $c=$ significantly different $(P<0.05)$ from the corresponding in the absence of glucose at the same temperature 


\section{Figure 3.1}

Western blot analysis of GSK3 protein content in brain, heart, kidney, liver and muscle of wood frogs from three conditions: control $\left(5^{\circ} \mathrm{C}\right.$ acclimated), frozen $\left(24 \mathrm{~h}\right.$ at $\left.-2.5^{\circ} \mathrm{C}\right)$ and thawed $\left(8 \mathrm{~h}\right.$ at $5^{\circ} \mathrm{C}$ after $24 \mathrm{~h}$ frozen)

(D) Representative Western blots showing GSK3 protein levels in tissues from control (C), frozen (F) and thawed (T) frogs.

(E) Relative levels of GSK3 protein in frozen and thawed frogs as compared with controls. Histograms shows mean $\pm \mathrm{SEM}, \mathrm{n}=4$ independent determinations.

Stars show values that are significantly different from the corresponding control for the same tissue as determined by the Student's t-test, $\mathrm{P}<0.05$. 
Figure 3.1

(A)

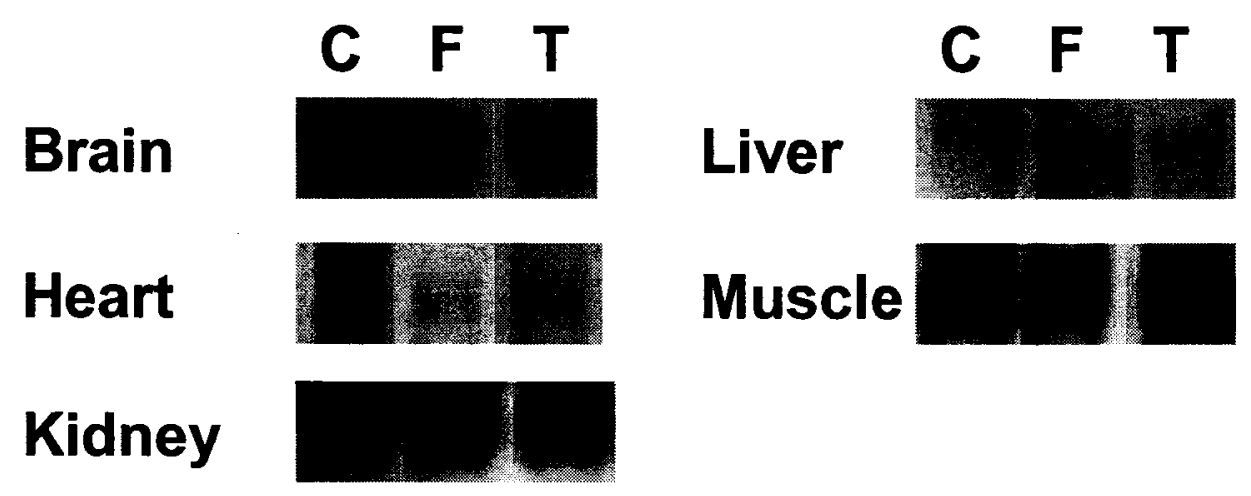

(B)

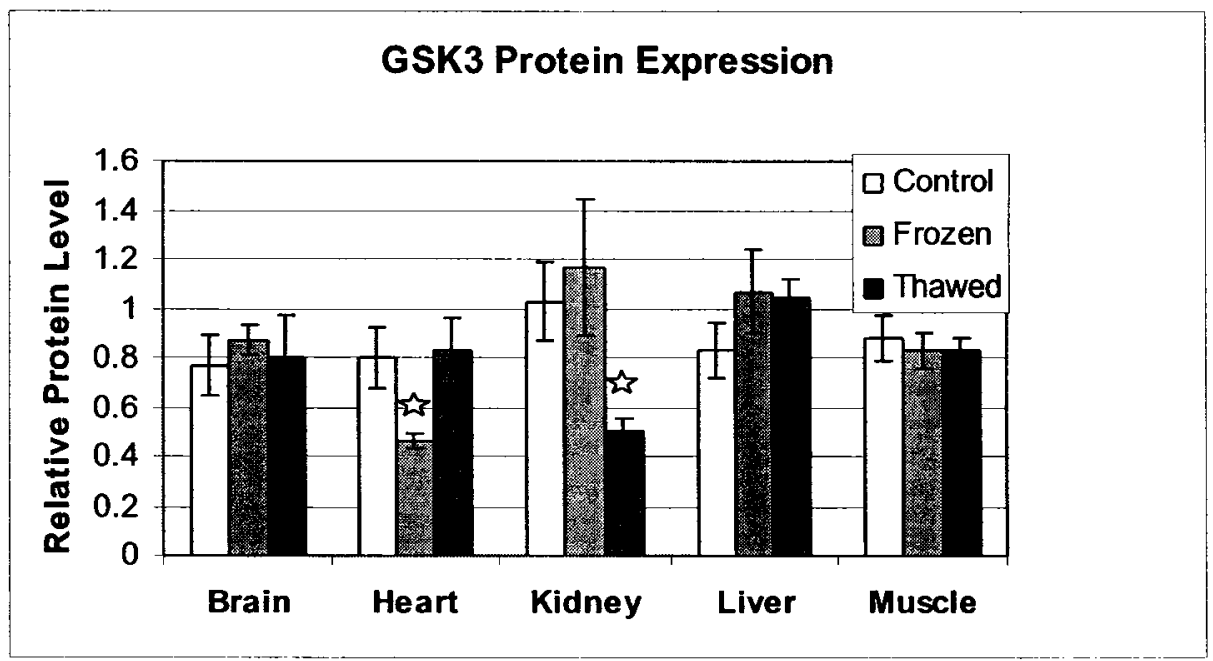




\section{Figure 3.2}

Western blot analysis of phospho-GSK3 (ser 9) protein content in brain, heart, kidney, liver and muscle of wood frogs from three conditions: control $\left(5^{\circ} \mathrm{C}\right.$ acclimated $)$, frozen $\left(24 \mathrm{~h}\right.$ at $\left.-2.5^{\circ} \mathrm{C}\right)$ and thawed $\left(8 \mathrm{~h}\right.$ at $5^{\circ} \mathrm{C}$ after $24 \mathrm{~h}$ frozen)

(A) Representative Western blots showing phospho-GSK3 (ser9) protein levels in tissues from control (C), frozen (F) and thawed (T) frogs.

(B) Relative levels of phospho-FOXO1 (ser9) protein in frozen and thawed frogs as compared with controls. Histograms shows mean \pm SEM, $n=4$ independent determinations.

Stars show values that are significantly different from the corresponding control for the same tissue as determined by the Student's t-test, $\mathrm{P}<0.05$. 
Figure 3.2

(A)

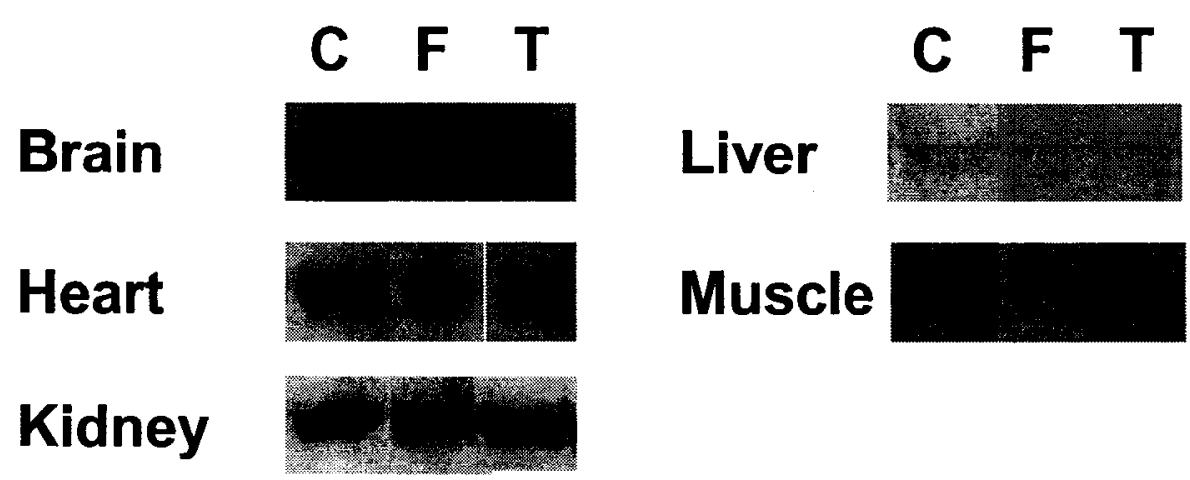

(B)

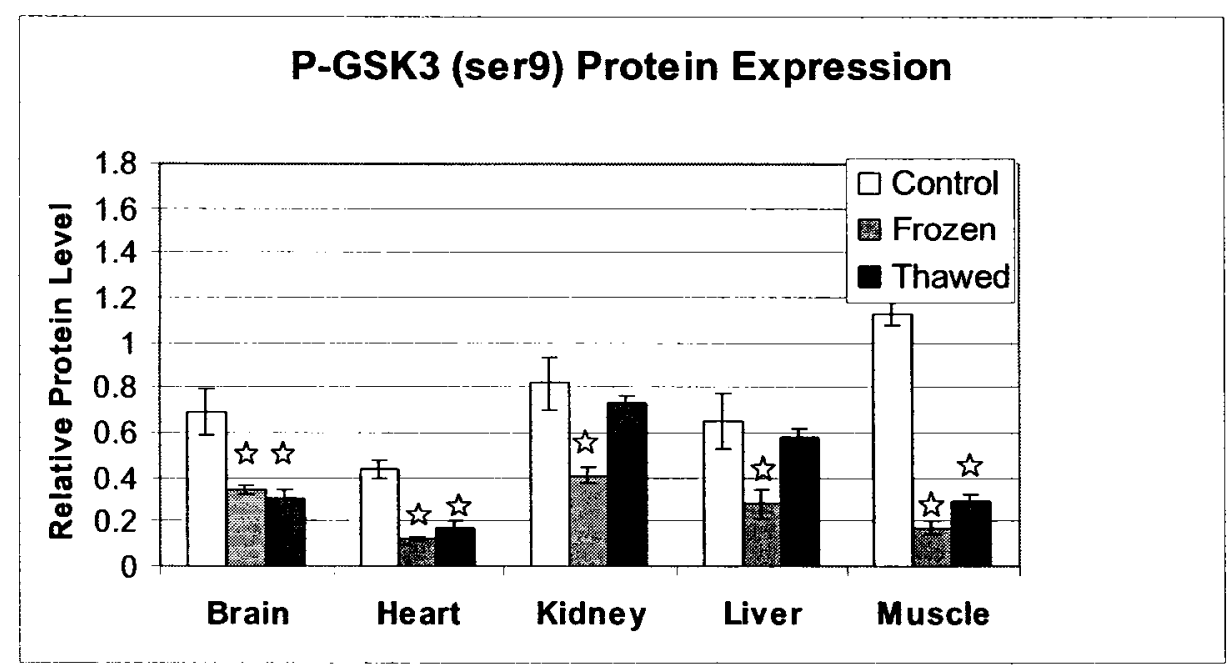


Figure 3.3

Velocity of GSK3 (in units/mg of GSK3) in Rana sylvatica muscle with increasing peptide concentration at $22{ }^{\circ} \mathrm{C}$. Control frog tissue was obtained from frogs acclimated at $5^{\circ} \mathrm{C}$ and frozen frog tissue was obtained from frogs frozen at $2.5^{\circ} \mathrm{C}$ for 24 hours. One unit is defined as the amount of enzyme that phosphorylates $1 \mu \mathrm{mol}$ of peptide per minute. 
Figure 3.3

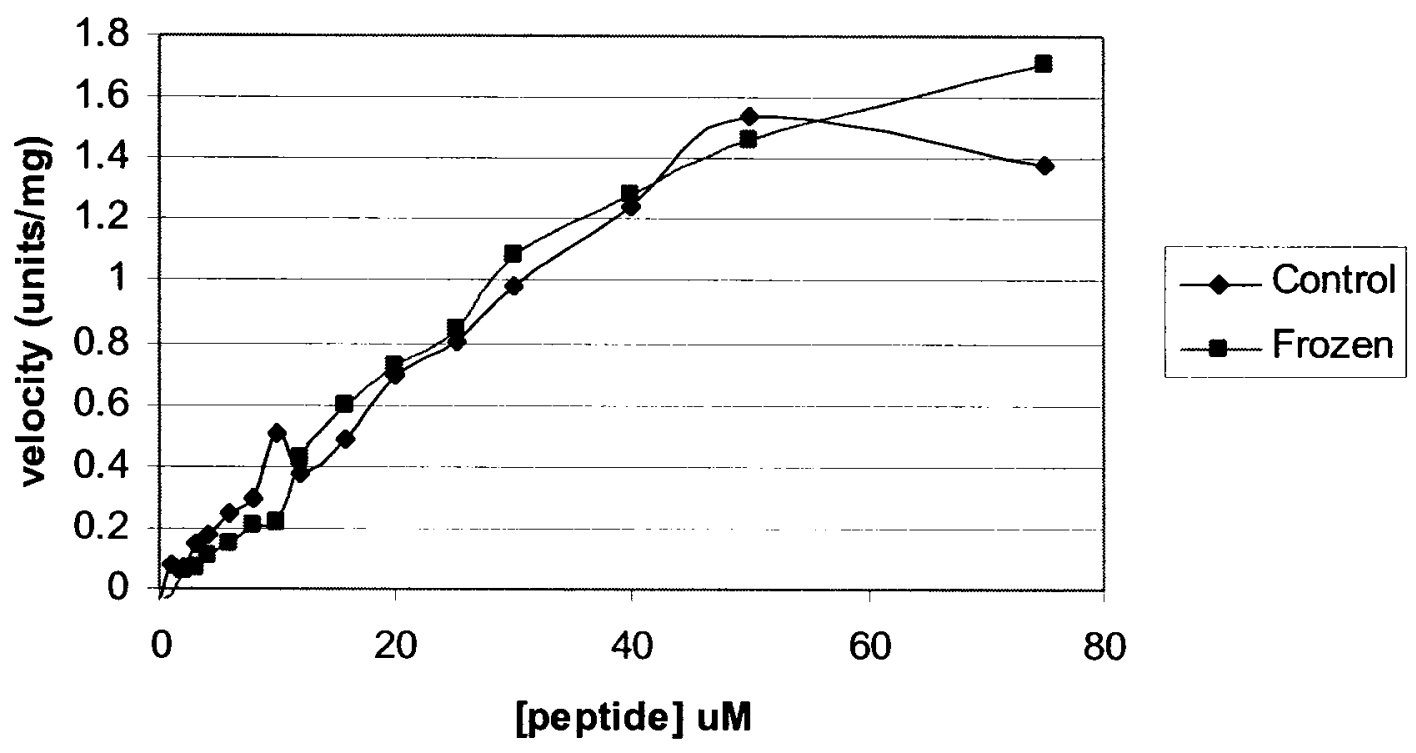

68 
Figure 3.4

Velocity of GSK3 (in units/mg of GSK3) in Rana sylvatica muscle with increasing peptide concentration at $4{ }^{\circ} \mathrm{C}$. Control frog tissue was obtained from frogs acclimated at 5 ${ }^{\circ} \mathrm{C}$ and frozen frog tissue was obtained from frogs frozen at $2.5^{\circ} \mathrm{C}$ for 24 hours. One unit is defined as the amount of enzyme that phosphorylates $1 \mu \mathrm{mol}$ of peptide per minute. 
Figure 3.4

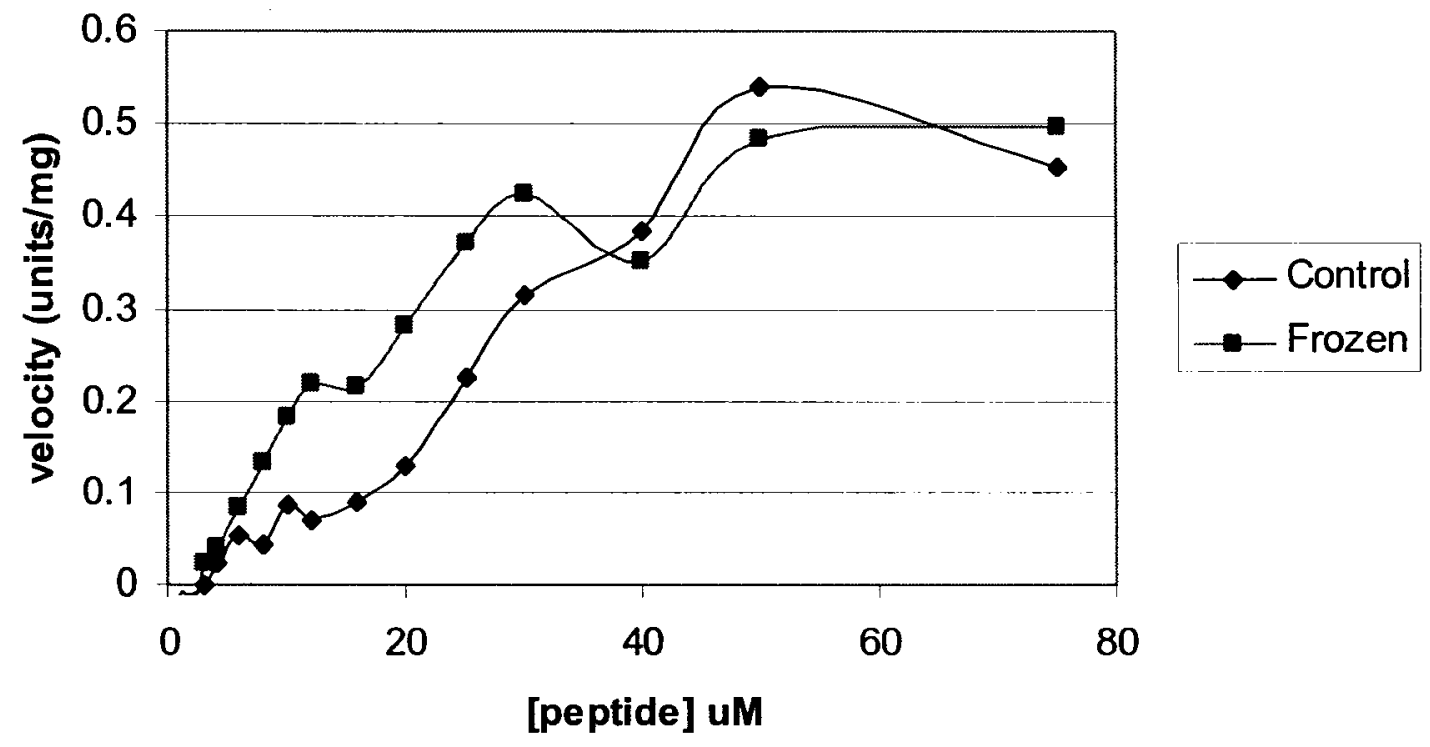




\section{Figure 3.5}

Velocity of GSK3 (in units/mg of GSK3) in Rana sylvatica muscle with increasing peptide concentration at $22^{\circ} \mathrm{C}$. Each assay contained $250 \mathrm{mM}$ glucose. Control frog tissue was obtained from frogs acclimated at $5^{\circ} \mathrm{C}$ and frozen frog tissue was obtained from frogs frozen at $2.5^{\circ} \mathrm{C}$ for 24 hours. One unit is defined as the amount of enzyme that phosphorylates $1 \mu \mathrm{mol}$ of peptide per minute. 
Figure 3.5

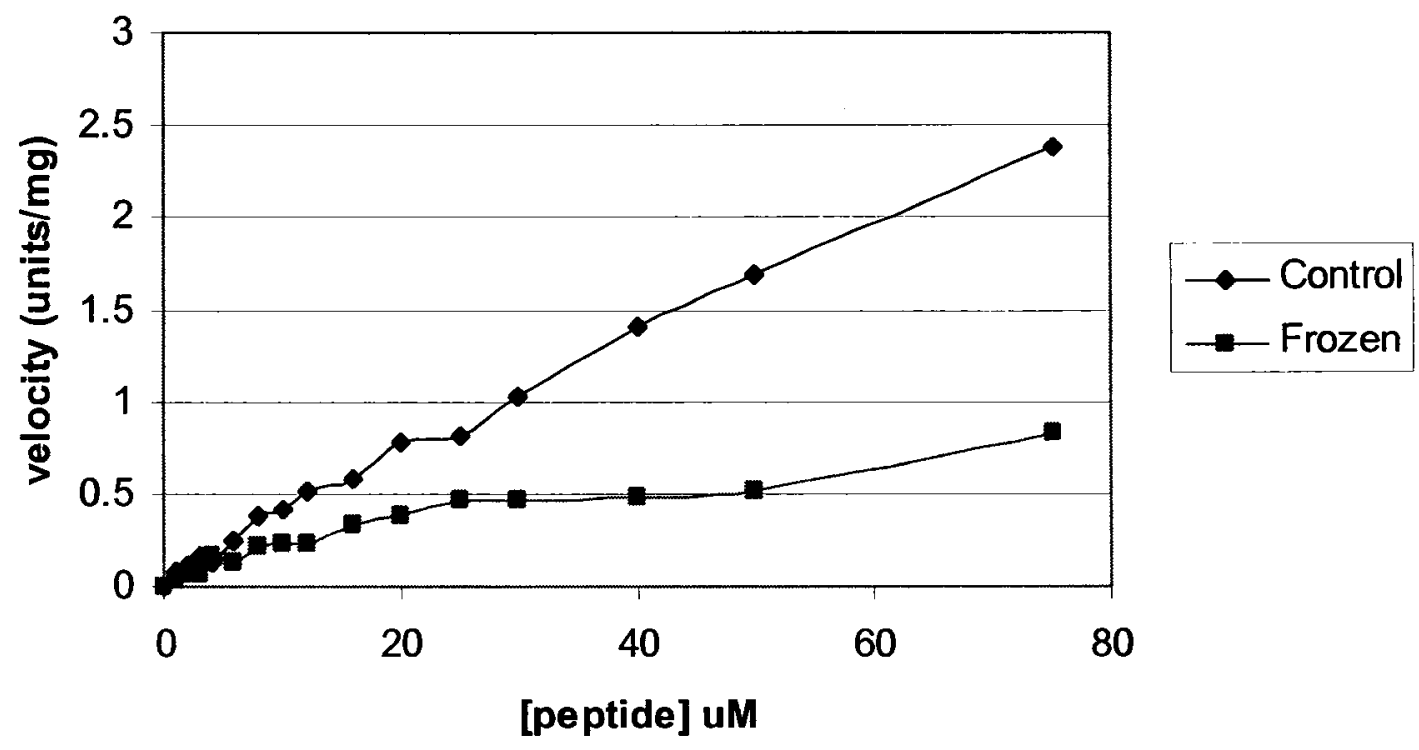




\section{Figure 3.6}

Velocity of GSK3 (in units/mg of GSK3) in Rana sylvatica muscle with increasing peptide concentration at $4{ }^{\circ} \mathrm{C}$. Each assay contained $250 \mathrm{mM}$ glucose. Control frog tissue was obtained from frogs acclimated at $5^{\circ} \mathrm{C}$ and frozen frog tissue was obtained from frogs frozen at $2.5^{\circ} \mathrm{C}$ for 24 hours. One unit is defined as the amount of enzyme that phosphorylates $1 \mu \mathrm{mol}$ of peptide per minute. 
Figure 3.6

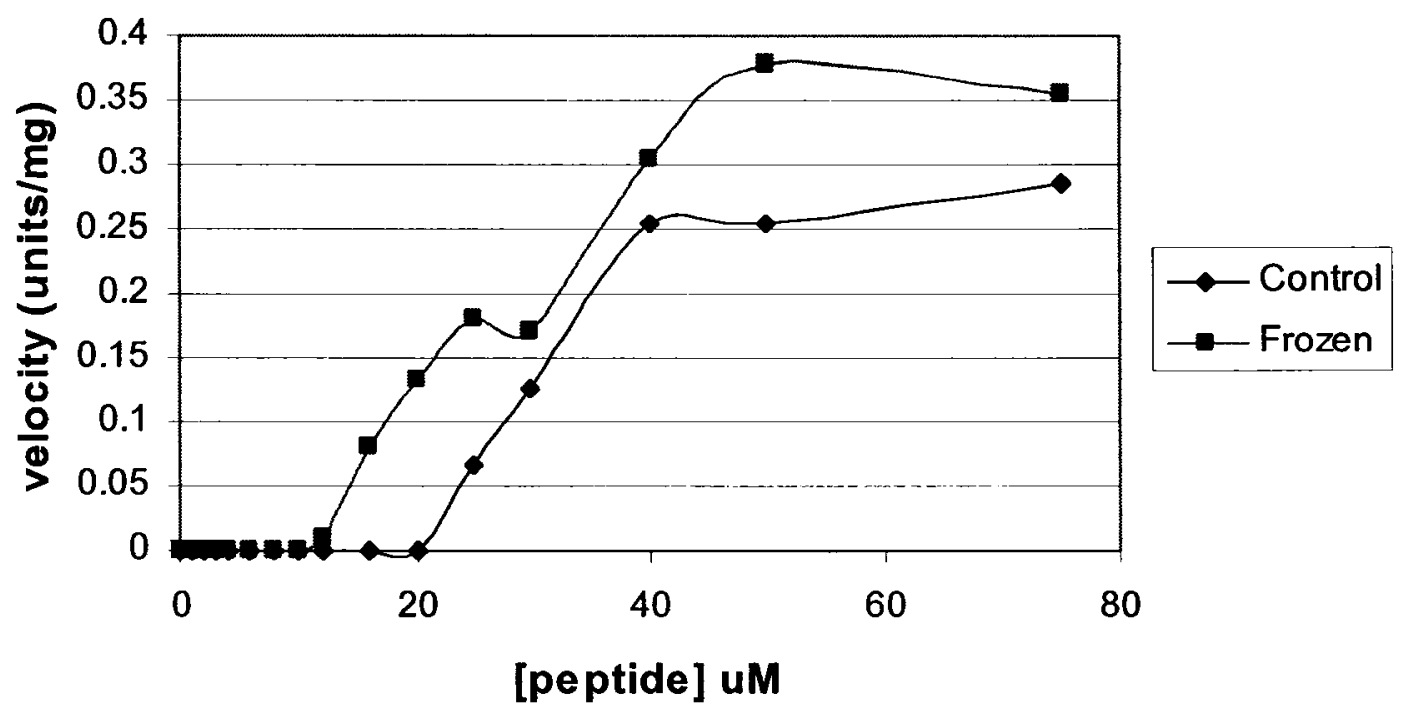




\section{Figure 3.7}

Activity of GSK3 with various metabolites ( $5 \mathrm{mM} \mathrm{G6P,} 10 \mathrm{mM}$ alanine, $10 \mathrm{mM}$ aspartate, $5 \mathrm{mM}$ succinate, $1 \mathrm{mM}$ AMP, $5 \mathrm{mM}$ PEP, $250 \mathrm{mM}$ glucose) for control (acclimated at $5^{\circ} \mathrm{C}$ ) and frozen $\left(24 \mathrm{~h}\right.$ at $\left.2.5^{\circ} \mathrm{C}\right)$ wood frogs. The assays were performed at $22{ }^{\circ} \mathrm{C}$. Histograms shows mean $\pm \mathrm{SEM}, \mathrm{n}=4$ independent determinations. The bars represent percent of activity compared to GSK 3 with no metabolites. Stars show values that are significantly different from the corresponding control with the same metabolite, and diamonds show values that are significantly different from the activity with no metabolite, as determined by the Student's t-test, $\mathrm{P}<0.05$. 
Figure 3.7

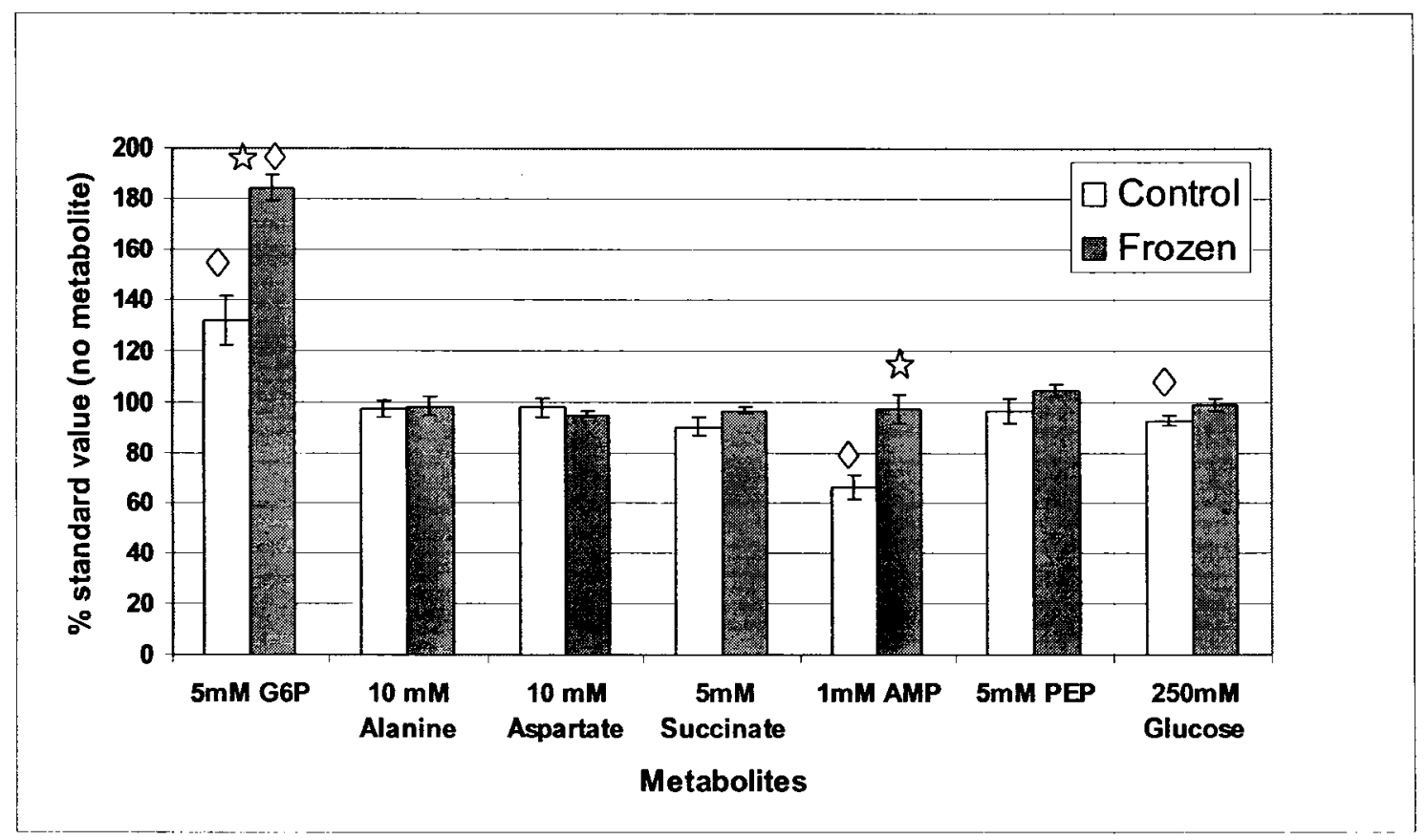




\section{Figure 3.8}

Activity of GSK3 with various metabolites ( $5 \mathrm{mM}$ G6P, $10 \mathrm{mM}$ alanine, $10 \mathrm{mM}$ aspartate, $5 \mathrm{mM}$ succinate, $1 \mathrm{mM}$ AMP, $5 \mathrm{mM}$ PEP, $250 \mathrm{mM}$ glucose) for control (acclimated at $5^{\circ} \mathrm{C}$ ) and frozen $\left(24 \mathrm{~h}\right.$ at $2.5^{\circ} \mathrm{C}$ ) wood frogs. The assays were performed at $4^{\circ} \mathrm{C}$. Histograms shows mean $\pm S E M, n=4$ independent determinations. The bars represent percent of activity compared to GSK3 with no metabolites. Stars show values that are significantly different from the corresponding control with the same metabolite, and diamonds show values that are significantly different from the activity with no metabolite, as determined by the Student's t-test, $\mathrm{P}<0.05$. 
Figure 3.8

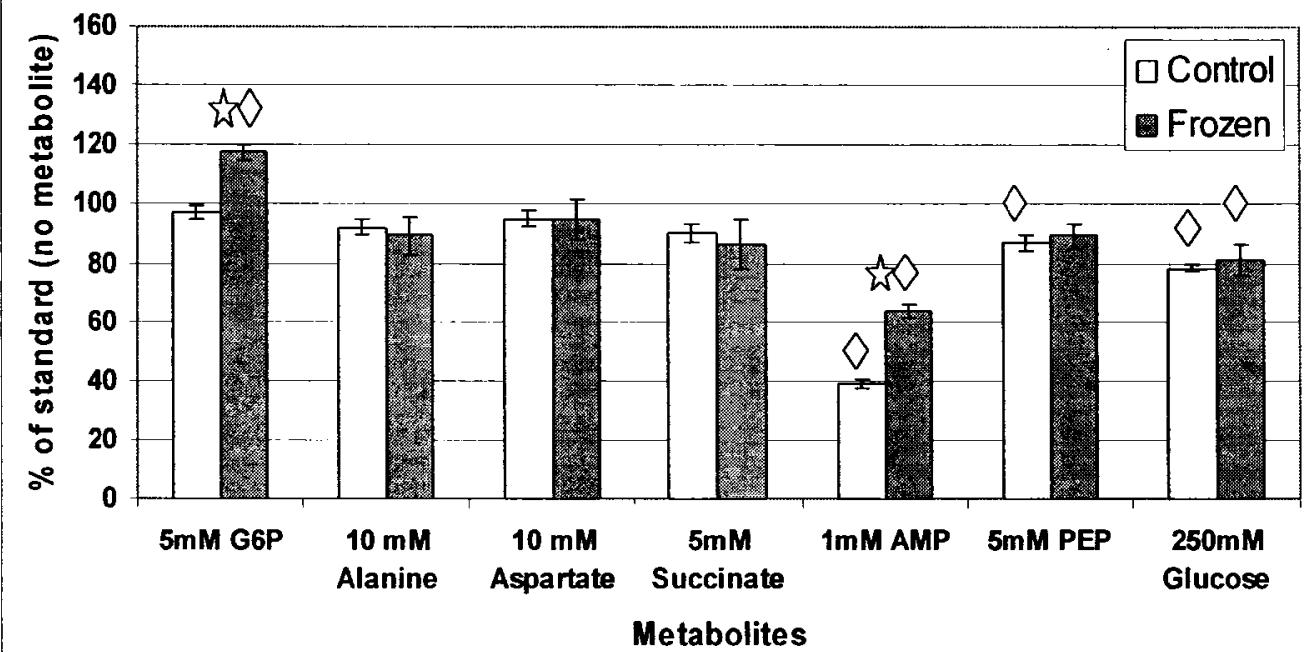


Figure 3.9

General schematic showing the regulation of glycogen synthesis and breakdown. 
Figure 3.9

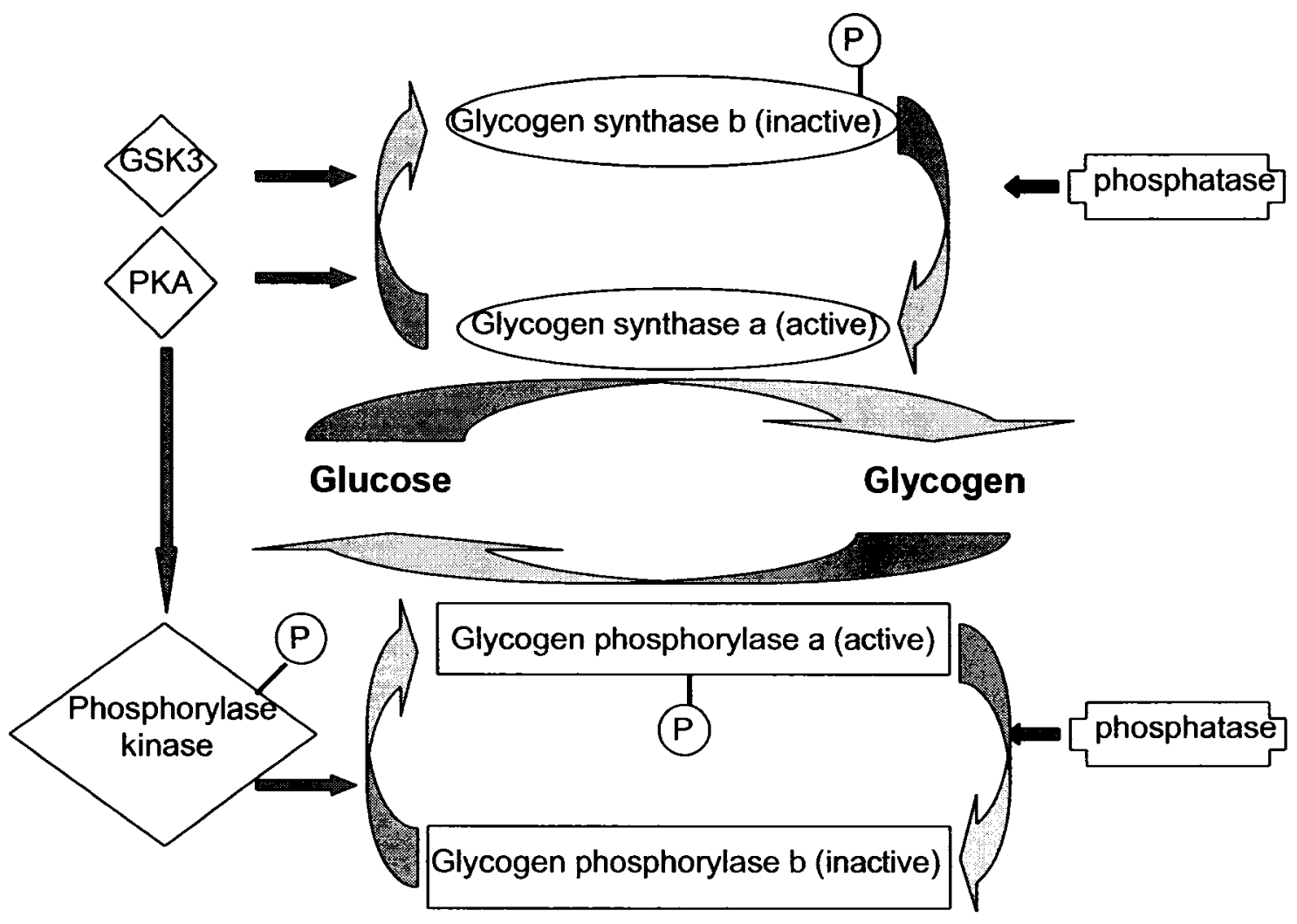




\section{CHAPTER 4:}

\section{General Discussion}




\section{The Wood Frog}

The wood frog, Rana sylvatica, is the primary animal used for studies of vertebrate freeze tolerance and is able to survive weeks completely frozen. When the frog is frozen, oxygen-dependent energy production is stopped and intertissue transport of fuels is halted. To survive weeks of freeze-induced ischemia, the wood frog must find ways to survive on fixed supplies of fermentable fuels (mostly carbohydrates and some amino acids) and using just the ATP output from glycolysis which is just one-eighteenth of the amount available from the oxidative catabolism of carbohydrate. To do this, most ATP-consuming metabolic processes are strongly suppressed to $1-5 \%$ of normal, only keeping those of which are needed for survival. In this study, the activity of two signaling proteins involved in the insulin signal transduction cascade, Forkhead box other (FOXO) transcription factors and glycogen synthase kinase 3 (GSK3) were analyzed, and their role in the wood frog's ability to survive freezing was determined.

\section{Metabolic Rate Depression}

The ability to highly reduce metabolic rate and enter a hypometabolic state is a life-saving mechanism for many organisms. When animals are faced with environmental conditions that would limit their ability to survive, they can enter a state of dormancy until the conditions are acceptable. Some examples of environmental conditions that induce hypometabolism are: high and low temperature, oxygen deprivation, food restriction and water limitation (Storey and Storey, 1990). In most cases of hypometabolism, the organism experiences little or no change to the internal environment of their cells and organs, even though their metabolic rate is lowered to between 5 and 
$40 \%$ of the resting rate of the normal state. This lack of change enables a rapid arousal when favourable environmental conditions return (Guppy and Withers, 1999).

The rate of ATP utilization by ATP-consuming processes must match the rate of ATP production by central pathways of fuel catabolism to maintain homeostasis in any cell. To survive, all cells have ways of increasing ATP production when energy demand is high and of scaling back production when energy demand declines. Also, situations that limit ATP production will quickly affect the rates of ATP-utilizing processes. Studies have shown that the pathways of macromolecular biosynthesis (such as protein synthesis, RNA/DNA synthesis) are more sensitive to ATP availability than various other activities such as transmembrane ion pumping (Buttgereit and Brand, 1995). In stress intolerant organisms, a drop in ATP production due to a limitation such as oxygen depletion or ischemia leads quickly to an energy crisis in cells because the demand by ATP-utilizing reactions cannot be met. The key factor that allows long term survival in organisms that can enter hypometabolic states is, therefore, the ability to coordinate the suppression of ATP-utilizing reactions to match the rate of ATP production; the rate of ATP use by cellular reactions is rebalanced and reprioritized in order to achieve a net overall reduction in ATP turnover that can be sustained over the long term in the hypometabolic state. This typically involves shutting down energy expensive cellular activities such as biosynthesis, the cell cycle, growth/differentiation and minimizing the rates of ATP use by vital processes such as the maintenance of membrane potential difference. This latter is one of the most energy-expensive and energy-sensitive functions of cells. When ATP levels are low, membrane potential difference is quickly dissipated with many negative consequences due to a rapid imbalance in the opposing rates of ion transport across 
membranes by ATP-dependent ion pumps versus ATP-independent ion channels (PerezPinzon et al., 1992; Hochachka and Lutz, 2001). Stress tolerant organisms quickly suppress and rebalance the activities of ion pumps and ion channels so that membrane potential is maintained but at a much lower rate of ATP turnover.

Protein synthesis is another highly energy-expensive process, requiring about five ATP equivalents per peptide bond formed and consuming a substantial portion of the total ATP budget of all cells (e.g. $\sim 36 \%$ in normoxic turtle liver; Hochachka et al., 1996). Protein synthesis is well known to be affected by the availability of energy and amino acids and is suppressed, for example, during starvation or hypoxia (Casey et al., 2002; DeGracia et al., 2002; Mordier et al., 2002). Not surprisingly, suppression of protein synthesis is a key characteristic of hypometabolic states (Joplin and Denlinger, 1989) and, in addition, the proportion of cellular ATP turnover devoted to protein synthesis is greatly lowered in hypometabolism (Land et al., 1993). Primary control over protein synthesis is due to the strong regulation of ribosomal proteins, particularly selected initiation and elongation factors. Inhibition of translation initiation is often due to inhibitory control of the eukaryotic initiation factor 2 (eIF2). The mechanism involved is phosphorylation of the alpha-subunit of eIF2 (eIF2 $\alpha$ ) (Rhoads, 1993; Mikulits et al., 2000), phospho-eIF2 $\alpha$ being a dominant inhibitor of the guanine nucleotide exchange factor eIF2B to prevent the recycling of eIF $2 \alpha$ between successive rounds of peptide synthesis (Clemens, 2001; DeGracia et al., 2002).

Reversible protein phosphorylation is a major mechanism responsible for coordinating and rebalancing not just membrane ion transport and cellular protein synthesis but many other cell functions and plays a dominant role in regulating entry into 
hypometabolic states (Storey and Storey, 2004b). Not only does covalent modification mechanism allow for rapid changes in activity states of enzymes and functional proteins but it is easily reversible to allow a quick return to normal metabolic functions when environmental conditions permit. Reversible protein phosphorylation regulates the activities, kinetic properties, binding interactions and subcellular locations of a huge number of metabolic enzymes, signal transduction enzymes, functional proteins, and transcription factors. Signal transduction cascades use this technique for the transmission and amplification of signals starting from membrane receptors, spreading through multiple intermediary steps, and ending in the alteration of protein function or gene expression (Cowan and Storey, 2003; MacDonald, 2004).

The activities the FOXO transcription factor family as well as GSK3 are controlled by reversible protein phosphorylation. Both FOXO factors and GSK3 are inactivated by phosphorylation of various protein kinases acting at multiple phosphorylation sites. FOXO transcription factors and GSK3 also catalyze the reversible protein phosphorylation to control their downstream targets, either activating or repressing them. This study shows that when the wood frog is frozen, in general, there is a reduced amount of the phosphorylated forms of FOXO1 and FOXO3, which implies that these transcription factors are more active during freezing (and during anoxia for FOXO3). By being more active, they can upregulate the transcription of important downstream targets such as manganese superoxide dismutase and catalase to help deal with oxidative damage and also repress genes such as cyclin D1 to induce cell cycle arrest to conserve energy in the frozen state. This study also demonstrated that the relative amount of phosphorylated GSK3 was reduced during freezing in frog organs 
implying an opposite increase in the amount of dephosphorylated active enzyme in the frozen frog. GSK3 in muscle of frozen frogs also had a higher affinity for its substrate when compared to the enzyme in control tissue. A more active GSK 3 could then phosphorylate and regulate key enzymes as the frog enters the hypometabolic frozen state including the eukaryotic initiation factor 2B (an enzyme critical for translation initiation) and glycogen synthase (the final enzyme of glycogen biosynthesis). Phosphorylation of these enzymes by GSK3 renders them inactive, and would consequently inhibiting protein translation, to save energy, and glycogen synthesis, to maintain glucose pools as a cryoprotectant.

\section{Implications of the Insulin Pathway}

Insulin controls a wide variety of biological responses including stimulation of glucose uptake, glycogen, lipid and protein synthesis, antilipolysis, activation of transcription of specific genes, and modulation of cellular growth and differentiation. Protein phosphorylation and dephosphorylation is the main mechanism involved in mediating and coordinating the molecular actions of insulin.

The insulin receptor is an $\alpha 2 / \beta 2$ tetramer. The $\alpha$-subunit contains the insulin binding site and is located entirely at the extracellular face of the plasma membrane, whereas the $\beta$-subunit is a transmembrane peptide (Van Obberhen et al., 1981). The intracellular portion of the $\beta$-subunit contains the insulin-regulated tyrosine protein kinase (Kasuga et al., 1983). When insulin binds to the $\alpha$-subunit, it activates the tyrosine kinase in the $\beta$-subunit which leads to the autophosphorylation of tyrosine residues in several regions of the intracellular $\beta$-subunit and also to the phosphorylation of the insulin 
receptor substrate (IRS) proteins. Tyrosine-phosphorylated IRS-proteins generate downstream signals by direct binding to the $\mathrm{SH} 2$ domains of various signaling proteins. Several enzymes and adaptor proteins have been identified that associate with IRS proteins, including phosphatidylinositol-3-kinase (PI3K) (White, 1998).

One of the earliest steps in the insulin signaling pathway is the activation of PI3K. One of its major actions is to phosphorylate phosphatidylinositol 4,5-diphosphate $\left(\operatorname{Ptd} I n s(4,5) \mathrm{P}_{2}\right)$ to produce phosphatidylinositol 3,4,5-triphosphate $\left(\operatorname{Ptd} \operatorname{Ins}(3,4,5) \mathrm{P}_{3}\right)$ which is an important second messenger in signal transduction (Stephens et al., 1991). PI3K plays a major role in many insulin-regulated responses including the stimulation of glucose uptake (Clarke et al., 1994), general and growth-specific protein synthesis (Mendez et al., 1997) and cell growth and proliferation (Jhun et al., 1994). PI3K also participates in regulating the expression of key genes such as the phosphoenolpyruvate carboxykinase (PEPCK) and glucose-6-phosphatase (Agati et al., 1998 ; Dickens et al., 1998). Induction of hexokinase II (Osawa et al., 1996), glucose-6-phosphate dehydrogenase (Wagle et al., 1998), and GLUT4 gene expression (Valverde et al., 1999) also requires PI3K. In addition, the activation PI3K has been shown to be both necessary and sufficient for the activation of protein kinase $\mathrm{B}$ (PKB, also known as Akt). The primary mechanism for the activation of PKB is phosphorylation on two sites (Thr 308 and Ser 473). Phosphorylation at Thr 308 is achieved by the phosphoinositide-dependent protein kinase (PDK1) (Walker et al., 1998). The kinase responsible for Ser473 phosphorylation has not been cloned yet, but is tentatively named PDK2 (Alessi and Cohen, 1998). The mechanism for PKB activation involves interaction with PtdIns $(3,4,5) \mathrm{P}_{3}$ through its $\mathrm{PH}$ domain which recruits $\mathrm{PKB}$ to the plasma membrane and 
results in conformational changes to $\mathrm{PKB}$ so that Thr and Ser become accessible to phosphorylation by PDK1 and PDK2, respectively (Alessi et al., 1996b). Many PKB substrates have been identified and include, among others, $B A D, C R E B$, members of the forkhead family of transcription factors, Ik-B kinase, procaspase-9, GSK3 and mTOR/FRAP (Rodiguez-Viciana et al., 1994). The large variety of proteins that are phosphorylated by PKB explains why this kinase is a key mediator of cell proliferation, differentiation and survival.

Skeletal muscle is the major site of insulin-stimulated glucose uptake, and most of the glucose that enters human muscle fibers in response to insulin is deposited as glycogen. Insulin causes activation of glycogen synthase by promoting dephosphorylation of multiple sites on the enzyme (Lawrence and Roach, 1997). The enzyme GSK3 has been one of the best-studied kinases for glycogen synthase regulation. An insulin-triggered cascade leads to phosphorylation and inactivation of GSK3 mediated by the actions of PI3K and PKB (Akt) (Welsh and Proud, 1993). Insulin also plays a key role in the overall regulation of protein synthesis. Several initiation and elongation factors are regulated by the hormone, usually as a consequence of changes in their states of phosphorylation. Regulation of eukaryotic initiation factor-2B (eIF-2B) is a key step in translation initiation. eIF-2B is activated by insulin signaling via a PI3K mediated mechanism (Welsh and Proud, 1993) whereas the inactivation of eIF-2B is controlled by GSK3 (Welsh et al., 1997).

The insulin pathway is involved in important, but high ATP-consuming processes, such as the synthesis of glycogen, lipids and proteins, cellular growth and differentiation, and the transcription of specific genes. These processes are important in normal 
metabolic states, but under stressed states, they must be suppressed to conserve energy. For example, when the wood frog is frozen, its metabolic rate is depressed to conserve energy in order to extend its survival throughout the winter months. Since the insulin pathway consumes a lot of energy and since the wood frog needs to conserve energy in the frozen state, the insulin pathway needs to be turned off while the frog is frozen. The insulin pathway normally represses the activity of FOXO transcription factors and GSK3, but when the insulin pathway is turned off, these proteins are more active, which was seen in the results obtained in this study. Another reason for the insulin pathway to be less active during freezing is because the insulin pathway is involved in stimulating glucose uptake. When frozen, blood glucose levels of wood frogs rises to $150-300 \mathrm{mM}$, since it is used as a cryoprotectant. To keep blood glucose levels high, glucose uptake and its catabolism or reconversion to glycogen must be stopped, and since the insulin pathway is involved in stimulating glucose uptake, the insulin pathway needs to be turned off.

\section{Conclusion}

To survive whole body freezing for weeks during the winter months, the wood frog uses several energy-saving mechanisms that allow it to survive over the long term using only its internal fuel reserves. Metabolic rate depression, including reversible protein phosphorylation of many key target proteins, is a large part of this energy conservation mechanism. In addition, selected key genes need to be up-regulated to ensure survival. This study determined that two of the forkhead box 'other' transcription factors, FOXO1 and FOXO3, are kept active during freezing. These proteins are kept 
active because they are involved in oxidative damage prevention and cell-cycle arrest. In this study, GSK3 was also shown to be more active during freezing, presumably to inhibit protein translation and glycogen synthesis in the frozen state. Both FOXO factors and GSK3 are phosphorylated and inactivated by protein kinase B (also known as Akt), a downstream kinase of the insulin pathway (Figure 4.1). Since FOXO factors and GSK3 are both active during freezing, the insulin pathway must be turned off.

\section{Future Directions}

In the present study, I have looked at the implications of FOXO factors and GSK3 on the ability of the wood frog to survive whole body freezing. Both FOXO factors and GSK3 are phosphorylated and controlled by protein kinase B (also known as Akt), and so the properties of this enzyme should be examined. Radioactive kinase assays could be used to look at the activity of Akt in the control and frozen state. The effects of glucose, temperature and different metabolites could also be considered, similar to the GSK3 assays performed in this study. Downstream targets of both FOXO and GSK3 would also be valuable to study. Since FOXO1 and FOXO3 are transcription factors, the polymerase chain reaction could be used to look at changes in the mRNA levels of known downstream targets of FOXO signaling. Examples of important downstream targets of FOXO1 and FOXO3 are cyclin D1 for FOXO1 and MnSOD for FOXO3. Cyclin D1 is also a downstream target for phosphorylation by GSK3, and so the amount of total cyclin D1 protein and also the amount of phosphorylated cyclin D1 protein in the control and frozen wood frog could also be examined using Western blotting and phospho-specific antibodies. 
AMP was shown to have an inhibitory effect on the activity of GSK3 when present at a concentration of $1 \mathrm{mM}$. The physiological concentration of AMP was previously found to be in the $0.02-0.05 \mathrm{mM}$ range, which makes this result inaccurate in vivo. Since a high concentration of AMP inhibited the enzyme, it implies that adenylates have an effect on GSK3 activity. To study the effect of adenylates on the activity of GSK3, the concentration required for $50 \%$ inhibition of $\mathrm{GSK} 3\left(\mathrm{IC}_{50}\right)$ could be measured for different adenylates (ATP, ADP, AMP, A, IMP, I). 
Figure 4.1

The insulin pathway: phosphorylation of FOXO factors and GSK3 by Akt. 
Figure 4.1

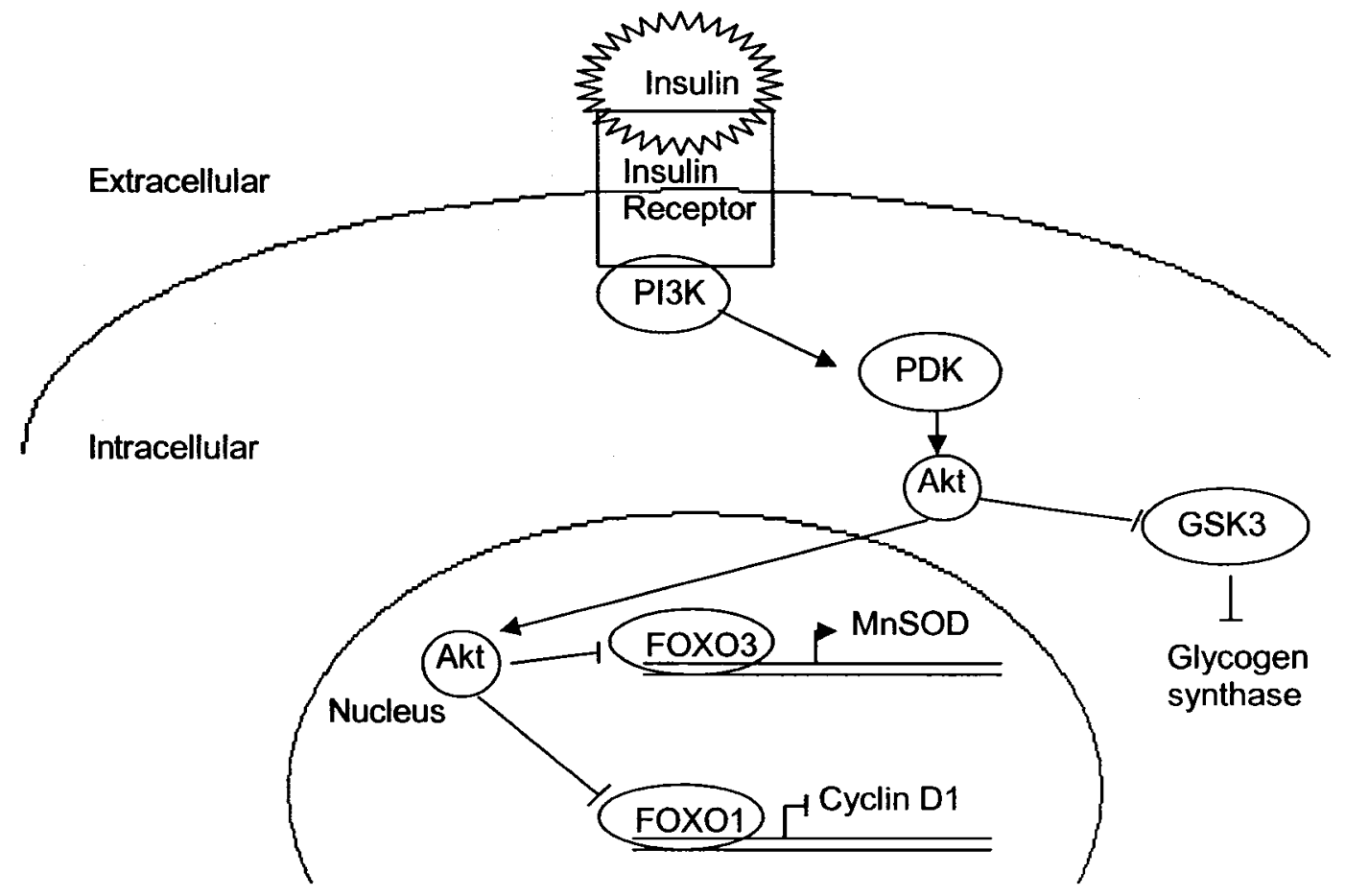




\section{References}

Agati, J.M., Yeagley, D., Quinn, P.G. (1998) Assessment of the roles of mitogenactivated protein kinase, phosphatidylinositol 3-kinase, protein kinase B, and protein kinase $\mathrm{C}$ in insulin inhibition of cAMP-induced phosphoenolpyruvate carboxykinase gene transcription. J. Biol. Chem. 273, 18751-18759.

Ahmad, S. (1995) Oxidative Stress and Antioxidant Defenses in Biology, New York: Chapman and Hall.

Alessi, D.R., Caudwell, F. B., Andjelkovic, M., Hemmings, B.A. and Cohen, P. (1996a) Molecular basis for the substrate specificity of protein kinase B; comparison with MAPKAP kinase-1 and p70 s6 kinase. FEBS Lett. 399, 333-338.

Alessi, D.R., Andjelkovic, M., Caudwell, B., Cron, P., Morrice, N., Cohen, P., Hemmings, B.A. (1996b) Mechanism of activation of protein kinase B by insulin and IGF-1. EMBO J. 15, 6541-6551.

Alessi, D.R., Cohen, P. (1998) Mechanism of activation and function of protein kinase B. Curr. Opin. Gene. Devel. 8, 55-62.

Armstrong, J.L.,Bonavaud, S.M., Toole, B.J., Yeaman, S.J. (2001) Regulation of glycogen synthesis by amino acids in cultured human muscle cells. J. Biol. Chem. $276,952-956$.

Barthel, A., Schmoll, D., Krüger, K.D.,Bahrenberg, G., Walther, R., Roth, R.A., Joost H.J. (2001) Differential regulation of endogenous glucose-6-phosphatase and phosphoenolpyruvate carboxykinase gene expression by the forkhead transcription factor FKHR in H4IIE-hepatoma cells. Biochem. Biophys. Res. Commun. 285, 897-902. 
Barthel, A., Schmoll, D., Unterman, T.G. (2005) FoxO proteins in insulin action and metabolism. Trends Endocrinol. Metab. 16, 183-189.

Behler, J.L., King, F.W. (1979) The Audubon society field guide to North American reptiles and amphibians, Alfred A. Knopf, New York.

Benson, E.E., Bremner, D. (2004) Oxidative stress in the frozen plant: a free radical point of view. In: Life in the frozen state (eds. E. Benson, B. Fuller, N. Lane), CRC Press, Boca Raton, pp. 205-242.

Bickler, P. E., Donohoe, P. H., Buck, L. T. (2001). The hypoxic brain: suppressing energy-expensive membrane functions by regulation of receptors and ion channels. In: Molecular Mechanisms of Metabolic Arrest (ed. K. B. Storey), BIOS Scientific Publishers, Oxford, pp. 77-102.

Biggs, W.H., Meisenhelder, J., Hunter T., Cavenee W.K, Arden K.C. (1999) Protein kinase B/Akt-mediated phosphorylation promotes nuclear exclusion of the winged helix transcription factor FKHR1. Proc. Natl, Acad. Sci. U.S.A. 96, 7421-7426.

Boyle, W.J., Smeal, T., Defize, L.H., Angel, P., Woodgett, J.R., Karin, M., Hunter, T. (1991) Activation of protein kinase C decreases phosphorylation of c-Jun at sites that negatively regulate its DNA-binding activity. Cell 64, 573-584.

Brooks, S.P.J. (1992) A simple computer program with statistical tests for the analysis of enzyme kinetics. BioTechniques 13, 906-911.

Brownawell, A. M., Kops, G. J., Macara, I. G., Burgering, B. M. (2001) Inhibition of nuclear import by protein kinase B (Akt) regulates the subcellular distribution and activity of the forkhead transcription factor AFX. Mol. Cell. Biol. 21, 3534-3546.

Brunet, A., Park, J., Tran, H., Hu, L.S., Hemmings, B.A., Greenberg, M.E. (2001) Protein 
kinase SGK mediates survival signals by phosphorylating the forkhead transcription factor FKHRL1 (FOXO3a). Mol. Cell. Biol. 21, 952-965.

Buttgereit, F., Brand, M. (1995). A hierarchy of ATP-consuming processes in mammalian cells. Biochem. J. 312, 163-167.

Carlsson, P., Mahlapuu, M. (2002) Forkhead transcription factors: key players in development and metabolism. Dev. Biol. 250, 1-23.

Casey, T. M., Pakay, J. L., Guppy, M., Arthur, P. G. (2002). Hypoxia causes downregulation of protein and RNA synthesis in noncontracting mammalian cardiomyocytes. Circ. Res. 90, 777-783.

Clark, K. L., Halay, E. D., Lai, E., Burley, S. K. (1993) Co-crystal structure of the HNF3/fork head DNA-recognition motif resembles histone H5. Nature 364, 412-420.

Clarke, J.F., Young, P.W., Yonezawa, K., Kasuga, M., Holman, G.D. (1994) Inhibition of the translocation of GLUT1 and GLUT4 in 3T3-L1 cells by the phosphatidylinositol 3-kinase inhibitor, wortmannin. Biochem. J. 300, 631-635.

Clemens, M. J. (2001). Initiation factor eIF2 alpha phosphorylation in stress responses and apoptosis. Prog. Mol. Subcell. Biol. 27, 57-89.

Cowan, K. J., Storey, K. B. (2003). Mitogen-activated protein kinases: new signaling pathways functioning in cellular responses to environmental stress. J. Exp. Biol $206,1107-1115$.

Cross , D.A., Alessi, D.R., Cohen, P., Andjelkovich M., Hemmings, B.A. (1995) Inhibition of glycogen synthase kinase- 3 by insulin mediated by protein kinase B. Nature 378, 785-789.

Czech, M. P. (2003) Insulin's expanding control of forkheads. Proc. Natl. Acad. Sci. 
U.S.A. $100,11198-11200$.

Dansen, T.B.,Kops, G.,Denis, S., Jelluma, N., Wanders, R., Bos, J.L., Burgering, B., Wirtz, K. (2004) Regulation of sterol carrier protein gene expression by the forkhead transcription factor FOXO3a. J. Lipid. Res. 45, 81-88.

DeGracia, D. J., Kumar, R., Owen, C. R., Krause, G. S., White, B. C. (2002). Molecular pathways of protein synthesis inhibition during brain reperfusion: implications for neuronal survival or death. J. Cereb. Blood Flow Metab. 22, 127-141.

Dent, P., Campbell, D.G., Hubbard, M.J., Cohen, P. (1989) Multisite phosphorylation of the glycogen-binding subunit of protein phosphatase-1G by cyclic AMPdependent protein kinase and glycogen synthase kinase-3. FEBS Lett. 248, 67-72.

Dickens, M., Svitek, C.A., Culbert, A.A., O’Brien, R.M., Tavare, J.M. (1998) Central role for phosphatidylinositide 3-kinase in the repression of glucose-6-phosphatase gene transcription by insulin. J. Biol. Chem. 273, 20144-20149.

Diehl, J.A., Cheng, M., Roussel, M.F. Sherr, C.J. (1998) Glycogen synthase kinase-3beta regulates cyclin D1 proteolysis and subcellular localization. Genes Dev. 12, 34993511.

Duman, J.G. (2001) Antifreeze and ice nucleator proteins in terrestrial arthropods. Annu. Rev. Physiol. 63, 327-357.

Durham, S. K., Suwanichkul, A., Scheimann, A. O., Yee, D., Jackson, J. G. Barr, F. G., Powell, D. R. (1999) FKHR bind the insulin response element in the insulin-like growth factor binding protein-1 promoter. Endocrinology 140, 3140-3146.

Embi, N., Rylatt, D.B., Cohen, P. (1980) Glycogen synthase kinase-3 from rabbit skeletal muscle. Separation from cyclic-AMP-dependent protein kinase and phosphorylase 
kinase. Eur. J. Biochem. 107, 519-527

Fang, X., Yu, S.X., Lu, Y., Bast, R.C., Woodgett, J.R., Mills, G.B. (2000)

Phosphorylation and inactivation of glycogen synthase kinase 3 by protein kinase A. Proc. Natl. Acad. Sci. USA 97, 11960-11965.

Fang, X., Yu, S., Tanyi, J.L., Lu, Y., Woodgett, J.R., Mills, G.B. (2002) Convergence of multiple signaling cascades at glycogen synthase kinase 3: Edg receptor-mediated phosphorylation and inactivation by lysophosphatidic acid through a protein kinase C-dependent intracellular pathway. Mol. Cell. Biol. 22, 2099-2110.

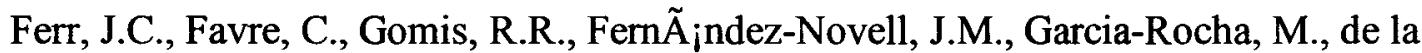
Iglesia, N., Cid, E., Guinovart, J.J. (2003) Control of glycogen deposition. FEBS Lett. 546, 127-132.

Fiol, C.J., Mahrenholz, A.M., Wang, Y., Roeske, R.W., Roach, P.J. (1987) Formation of protein kinase recognition sites by covalent modification of the substrate. Molecular mechanism for the synergistic action of casein kinase II and glycogen synthase kinase 3. J. Biol. Chem. 262, 14042-14048.

Fiol, C.J., Williams, J.S., Chou, C.H., Wang, Q.M., Roach, P.J. and Andrisani, O.M. (1994) A secondary phosphorylation of CREB341 at Ser129 is required for the cAMP-mediated control of gene expression. A role for glycogen synthase kinase3 in the control of gene expression. J. Biol. Chem. 269, 32187-32193.

Flotow, H., Graves, P.R., Wang, A.Q., Fiol, C.J., Roeske, R.W, Roach, P.J. (1990) Phosphate groups as substrates determinants for casein kinase I action. J. Biol. Chem. 265, 14264-14269.

Frame, S., Cohen, P., Biondi, R.M. (2001) A common phosphate binding site explains the 
unique substrate specificity of GSK3 and its inactivation by phosphorylation. Mol. Cell. 7, 1321-1327.

Frerichs, K. U., Smith, C. B., Brenner, M., DeGracia, D. J., Krause, G. S., Marrone, L., Dever, T. E., Hallenbeck, J. M. (1998). Suppression of protein synthesis in brain during hibernation involves inhibition of protein initiation and elongation. Proc. Natl. Acad. Sci. USA 95, 14511-14516.

Furuyama, T., Kitayama, K., Yamashita, H., Mori, N. (2003) Forkhead transcription factor FOXO1 (FKHR)-dependent induction of PDK4 gene expression in skeletal muscle during energy deprivation. Biochem J. 375, 365-371.

Guppy, M., Withers, P. (1999). Metabolic depression in animals: Physiological perspectives and biochemical generalisations. Biol. Rev. 74, 1-40.

Hand, S.C., Hardewig, I. (1996). Downregulation of cellular metabolism during environmental stress: mechanisms and implications. Ann. Rev. Physiol. 58, 539563.

Hers, H.G., Hue, L. (1983) Gluconeogenesis and related aspects of glycolysis. Ann. Rev. Biochem. 53, 617-653.

Hochachka, P.W., Buck, L.T., Doll, C.J., Land, S.C. (1996). Unifying theory of hypoxia tolerance: molecular/metabolic defense and rescue mechanisms for surviving oxygen lack. Proc. Natl. Acad. Sci. USA 93, 9493-9498.

Hochachka, P.W., Lutz, P.L. (2001). Mechanism, origin and evolution of anoxia tolerance in animals. Comp. Biochem. Physiol. B 130, 435-459.

Hofmann, G.E., Hand, S.C. (1992). Comparison of messenger RNA pools in active and dormant Artemia franciscana embryos: evidence for translational control. J. Exp. 
Biol. 164, 103-116.

Holden, C.P., Storey, K.B. (1996) Signal transduction, second messenger, and protein kinase responses during freezing exposures in wood frogs. Am. J. Physiol. 271, R1205-R1211.

Holden, C.P., Storey, K.B. (1997) Second messenger and cAMP-dependent protein kinase responses to dehydration and anoxia stresses in frogs. J. Comp. Physiol. B. $167,305-312$.

Hughes, K., Ramakrishna, S., Benjamin, W.B., Woodgett, J.R. (1992) Identification of multifunctional ATP-citrate lyase kinase as the alpha-isoform of glycogen synthase kinase-3. Biochem J. 288, 309-314.

Jhun, B.H., Rose, D.W., Seely, B.L. Rameh, L., Cantley, L., Saltiel, A.R., Olefsky, J.M. (1994) Microinjection of the SH2 domain of the 85-kilodalton subunit of phosphatidylinositol 3-kinase inhibits insulin-induced DNA synthesis and c-fos expression. Mol. Cel. Biol. 14, 7466-7475.

Joanisse, D.R., Storey, K.B. (1996) Oxidative damage and antioxidants in Rana sylvatica, the freeze-tolerant wood frog. Am. J. Physiol. 271, R545-R553.

Joplin, K.H., Denlinger, D.L. (1989). Cycles of protein synthesis during pupal diapause in the flesh fly Sarcophaga crassipalpis. Arch. Insect Biochem. Physiol. 12, 111122.

Kaestner, K.H., Knochel, W., Martinez, D.E. (2000) Unified nomenclature for the winged helix/forkhead transcription factors. Genes Dev. 14, 142-146.

Kasuga, M., Fujita-Yamaguchi, Y., Blithe, D., Kahn, C.R. (1983) Tyrosine-specific protein kinase activity is associated with the purified insulin receptor. Proc. Natl. 
Acad. Sci. USA. 80, 2137-2141.

Kops, G. J., Medema, R. H., Glassford, J., Essers, M. A., Dijkers, P. F., Coffer, P. J., Lam, E. W., Burgering, B. M. (2002a) Control of cell cycle exit and entry by protein kinase B-regulated forkhead transcription factors. Mol. Cell. Biol. 22, 2025-2036

Kops, G. J., Dansen, T. B., Polderman, P. E., Saarloos, I., Wirtz, K. W., Coffer, P. J., Huang, T. T., Bos, J. L., Medema, R. H., Burgering, B. M. (2002b) Forkhead transcription factor FOXO3a protects quiescent cells from oxidative stress. Nature $419,316-321$

Kristal, B.S. and Yu, B.P. (1992) An emerging hypothesis: synergistic induction of aging by free radicals and Maillard reactions. J. Gerontol. 471, B107-B114.

Land, S.C., Buck, L.T., Hochachka, P.W. (1993). Response of protein synthesis to anoxia and recovery in anoxia-tolerant hepatocytes. Amer. J. Physiol. 265, R41-R48.

Larade, K., Storey, K. (2002). Reversible suppression of protein synthesis in concert with polysome disaggregation during anoxia exposure in Littorina littorea. Mol. Cell. Biochem. 232, 121-127.

Lawrence, J.C., Roach, P.J. (1997) New insights into the role and mechanism of glycogen synthase activation by insulin. Diabetes $46,541-547$.

Layne, J.R., Lee, R.E. (1987) Freeze tolerance and the dynamics of ice formation in wood frogs (Rana sylvatica) from southern Ohio. Can J. Zool. 65, 2062-2065.

Layne, J.R., Costanzo, J.P. Lee, R.E. (1998) Freeze duration influences postfreeze survival in the frog Rana sylvatica. J. Exp. Zool. 280, 197-211.

Li, M., Wang, X., Meintzer, M.K., Laessig, T., Birnbaum, M.J., Heidenreich, K.A. 
(2000) Cyclic AMP promotes neuronal survival by phosphorylation of glycogen synthase kinase 3 beta. Mol. Cell. Biol. 20, 9356-9363.

MacDonald, J. A., Storey, K.B. (2002) Protein phosphatase type-1 from skeletal muscle enzyme of the freeze tolerant wood frog. Comp. Biochem. Physiol. B 131, 27-36

MacDonald, J. A. (2004). Signal transduction pathways and the control of cellular responses to external stimuli. In Functional Metabolism: Regulation and Adaptation (ed. K. B. Storey), pp. 87-123. Hoboken, NJ: Wiley-Liss.

Mendez, R., Kollmorgen, G., White, M.F., Rhoads, R.E. (1997) Requirement of protein kinase $\mathrm{C}$ zeta for stimulation of protein synthesis by insulin. Mol. Cell. Biol. 17, $5184-5192$.

Mikulits, W., Pradet-Balade, B., Habermann, B., Beug, H., Garcia-Sanz, J.A., Mullner, E.W. (2000). Isolation of translationally controlled mRNAs by differential screening. FASEB J. 14, 1641-1652.

Mordier, S., Bruhat, A., Averous, J., Fafournoux, P. (2002). Cellular adaptation to amino acid availability: mechanisms involved in the regulation of gene expression and protein metabolism. In Cell and Molecular Responses to Stress (eds. K. B. Storey and J. M. Storey), Vol. 3, pp. 189-206. Elsevier Press, Amsterdam.

Nakae, J., Kitamura, T.,Silver, D.L., Accili, D. (2001) The forkhead transcription factor FOXO1 (Fkhr) confers insulin sensitivity onto glucose-6-phosphatase expression. J. Clin. Invest. 108, 1359-1367.

Nakamura, N., Ramaswamy, S., Vazquez, F., Oretti, S., Loda, M., Sellers, W. R. (2000) Forkhead transcription factors are critical effectors of cell death and cell cycle arrest downstream of PTEN. Mol. Cell. Biol. 20, 8969-8982. 
Nemoto, S., Finkel, T. (2002) Redox regulation of forkhead proteins through a p66shcdependent signaling pathway. Science $295,2450-2452$.

Osawa, H., Sutherland, C., Robey, R.B., Printz, R.L., Granner, D.K. (1996) Analysis of the signaling pathway involved in the regulation of hexokinase II gene transcription by insulin. J. Biol. Chem. 271, 16690-16694.

Parker, P.J.J., Caudwell, F.B., Cohen, P. (1983) Glycogen synthase from rabbit skeletal muscle: effect of insulin on the state of phosphorylation of the seven phosphoserine residues in vivo. Eur. J. Biochem. 130, 227-234

Perez-Pinzon, M.A., Rosenthal, M., Sick, T.J., Lutz, P.L., Pablo, J., Mash, D. (1992). Downregulation of sodium channels during anoxia: a putative survival strategy of turtle brain. Amer. J. Physiol. 262, R712-R715.

Pierrou, S., Hellqvist, M., Samuelsson, L., Enerback, S., Carlsson, P. (1994) Cloning and characterization of seven human forkhead proteins: binding site specificity and DNA bending. EMBO J. 13, 5002-5012.

Pulverer, B.J., Fisher, C., Vousden, K., Littlewood, T., Evan, G. Woodgett, J.R. (1994) Site-specific modulation of c-Myc cotransformation by residues phosphorylated in vivo. Oncogene $9,59-70$.

Rhoads, R. (1993). Regulation of eukaryotic protein synthesis by initiation factors. J. Biol. Chem. 268, 3017-3020.

Rodiguez-Viciana, P., Warne, P.H., Dhand, B., Vanhaesebrock, I., Gout, M.J., Fry, M.D., Waterfield, M.D., Downward, J. (1994) Phosphatidylinositol-3-OH kinase direct target of Ras. Nature $370,527-532$.

Rubinsky, B., Lee, C.Y., Bastacky, J. Onik, J. (1987) The process of freezing and the 
mechanism of damage during hepatic cryosurgery. Cryobiology 27, 8-97.

Rubinsky, B., Wong, S.T.S., Hong, J.-S., Gilbert, J., Roos, M., Storey, K.B. (1994) ${ }^{1}$ H magnetic resonance imaging of freezing and thawing in freeze-tolerant frogs. Am. J. Physiol. 266, R1771-1777

Sabbah, M., Courilleau, D., Mester, J., Redeuih, G. (1999) Estrogen induction of the cyclin D1 promoter: involvement of a cAMP response-like element. Proc. Natl. Acad. Sci. USA 96, 11217-11333

Saito, Y., Vandenheede, J.R., Cohen, P. (1994) The mechanism by which epidermal growth factor inhibits glycogen synthase kinase 3 in A431 cells. Biochem. J. 303, 27-31.

Schmidt, M., de Mattos, S. F., van der Horst, A., Klompmaker, R., Kops, G. J., Lam, E. W., Burgering, B. M., Medema, R. H. (2002) Cell cycle inhibition by FoxO forkhead transcription factors involves downregulation of cyclin D. Mol. Cell. Biol. 22, 7842-7852.

Shaw, M., Cohen, P. (1999) Role of protein kinase B and the MAP kinase cascade in mediating the EGF-dependent inhibition of glycogen synthase kinase 3 in Swiss 3 T3 cells. FEBS Lett. 461, 120-124.

Singh, L.P., Denslow, N.D., Wahba, A.J. (1996) Modulation of rabbit reticulocyte guanine nucleotide exchange factor activity by casein kinases 1 and 2 and glycogen synthase kinase 3. Biochemistry 5, 3206-3212.

Stambolic, V., Woodgett, J.R. (1994) Mitogen inactivation of glycogen synthase kinase3beta in intact cells via serine 9 phosphorylation. Biochem. J. 303, 701-704.

Stephens, L.R., Hughes, K.T., Irvine, R.F. (1991) Pathway of phosphatidylinositol 
$(3,4,5)$-trisphosphate synthesis in activated neutrophils. Nature 351, 33-39.

Storey, K.B. (1987) Organ-specific metabolism during freezing and thawing in a freezetolerant frog. Am. J. Physiol. 253, R292-297.

Storey, K.B. (1987b) Glycolysis and the regulation of cryoprotectant synthesis in liver of the freeze tolerant wood frog. J. Comp. Physiol. B. 137, 373-380.

Storey, K.B. (1993) Molecular mechanisms of metabolic arrest in mollusks. In Surviving Hypoxia: Mechanism of Control and Adaptation (eds. Hochachka, P.W., Lutz, P.L., Sick, T.J., Rosenthal, M. Thillart, G. van den), CRC Press, Boca Raton, pp. 253-269.

Storey, K.B., Storey, J.M. (1984) Biochemical adaptation for freezing tolerance in the wood frog, Rana sylvatica. J. Comp. Physiol. B. 155, 29-36.

Storey, K.B., Storey, J.M. (1985) Freeze tolerant frogs: cryoprotectants and tissue metabolism during freeze-thaw cycles. Can. J. Zool. 64, 49-56.

Storey, K.B., Storey, J.M. (1988) Freeze tolerance in animals. Physiol. Rev. 68, 27-84.

Storey, K.B., Storey, J.M. (1990). Facultative metabolic rate depression: molecular regulation and biochemical adaptation in anaerobiosis, hibernation and aestivation. Quart. Rev. Biol. 65, 145-174.

Storey, K.B., Storey, J.M. (1992) Natural Freeze tolerance in ectothermic vertebrates. Ann. Rev. Physiol. 54, 619-637.

Storey, K.B., Storey, J.M. (2004) Physiology, biochemistry and molecular biology of vertebrate freeze tolerance: the wood frog, In Life in the Frozen State (eds. E. Benson, B. Fuller, N. Lane), CRC Press, Boca Raton, pp. 243-274.

Storey, K. B., Storey, J. M. (2004a). Metabolic rate depression in animals: transcriptional 
and translational controls. Biol. Rev. Camb. Philos. Soc. 79, 207 -233.

Storey, J.M., Storey, K.B. (2004b) Cold hardiness and freeze tolerance. In: Functional Metabolism: Regulation and Adaptation (ed. Storey, K.B.) Wiley-Liss, Hoboken, NJ, pp. 473-503

Storey, K.B., Storey, J.M. (2005) Biochemical adaptations to extreme environments. In Integrative Physiology in the Proteomics and Post-Genomics Age (ed. Walz, W.) Humana Press, New Jersey, pp. 169-200.

Tran, H., Brunet, A., Grenier, J. M. Datta, S. R. Fornace Jr., A. J., DiStefano, P. S., Chiang, L. W., Greenberg, M. E. (2002) DNA repair pathway stimulated by the forkhead transcription factor FOXO3a through the Gadd45 protein. Science 296, $530-534$

Valverde, A.M., Navarro, P., Teruel, T., Conejo, R., Benito, M., Lorenzo, M. (1999) Insulin and insulin-like growth factor I up-regulate GLUT4 gene expression in fetal brown adipocytes, in a phosphoinositide 3-kinase-dependent manner. Biochem. J. 337: 397-405.

Van der Heide, L., Hoekman, M. F. M., Smidt, M. (2004) The ins and outs of FoxO shuttling: mechanisms of FoxO translocation and transcriptional regulation. Biochem. J. (2004) 297-309.

Van der Horst, A., Burgering, B.M.T. (2007) Stressing the role of FoxO proteins in lifespan and disease. Nat. Rev. 8, 440-450.

Van Obberghen, E., Kasuga, M., LeCam, A., Itin, A., Hedo, J.-A., Harrison, L.C. (1981) Biosynthetic labeling of insulin receptor: studies of subunits in cultured human IM-9 lymphocytes. Proc. Natl. Acad. Sci. USA. 78, 1052-1056. 
Wagle, A., Jivraj, S., Garlock, G.L., Stapleton, S.R. (1998) Insulin regulation of glucose6-phosphate dehydrogenase gene expression is rapamycin-sensitive and requires phosphatidylinositol 3-kinase J. Biol. Chem. 273, 14968-14974.

Walker, K.S., Deak, M., Patterson, A., Hudson, K., Cohen, P., Alessi, D.R. (1998) Activation of protein kinase $\mathrm{B} \beta$ and $\gamma$ isoforms by insulin in vivo and by 3phosphoinositide-dependent protein kinase-1 in vitro: comparison with protein kinase B. Biochem. J. 331, 299-308.

Weigel, D., Jackle, H. (1990) The forkhead domain: a novel DNA binding motif of eukaryotic transcription factors? Cell 63: 455-456.

Welsh, G.I., Proud, C.G. (1993) Glycogen synthase kinase-3 is rapidly inactivated in response to insulin and phosphorylates eukaryotic initiation factor eIF-2B. Biochem J. 294, 625-629.

Welsh, G.I., Stokes, C.M. Wang, X., Sakaue, H., Ogawa, W.,m KIasuga, M., Proud, C.G. (1997) Activation of translation initiation factor eIF2B by insulin requires phosphatidyl inositol 3-kinase. FEBS Lett. 410, 418-422.

White, M.F. (1998) The IRS-signaling system: A network of docking proteins that mediate insulin action Mol. Cell. Biochem. 182, 3-11.

Wilson, W., Skurat, A., Probst, B., Paoli-Roach, A., Roach, P., Rutter, J. (2005) Control of mammalian glycogen synthase by PAS kinase. Proc. Natl. Acad. Sci. U.S.A. $102,16596-16601$.

Wolff, S.P, Jiang, Z.Y. Hunt, J.V. (1991) Protein glycation and oxidative stress in diabetes mellitus and aging. Free Rad. Biol. Med. 10, 339-352.

Woodgett, J.R. (1990) Molecular cloning and expression of glycogen synthase kinase- 
3/factorA. EMBO J. 9, 2431-2438.

Woodgett, J.R. (1991) cDNA cloning and properties of glycogen synthase kinase-3. Methods Enzymol. 200, 564-577.

Woods, A.K., Storey, K.B. (2006) Vertebrate freezing survival: regulation of the multicatalytic proteinases complex and controls on protein degradation. Biochim. Biophys. Acta 1760, 395-403.

Woods,Y.L., Rena, G., Morrice, N., Bathel, A., Becker, W., Guo, S., Unterman, T.G. Cohen, P. (2001) The kinase DYRK1A phosphorylates the transcription factor FKHR at ser 329 in vitro, a novel in vivo phosphorylation site. Biochem. J. 355, 597-607.

Woods, T.G., Prescott, A.R., Peggie, M., Unterman, T.G., Williams, M.R. and Chen, P. (2002) Two novel phosphorylation sites on FKHR that are critical for its nuclear exclusion. EMBO J. 21, 1556-1562.

Zhang, W., Patil, S., Chauhan, B., Guo, S., Powell, D.R., Lee, J., Klotsas, A., Matika, R.,Xiao, X., Franks, R., Heidenreich, K.A., Sajan, M., Farese, R.V., Beer Stolz, D., Tso, P., Koo, S., Montminy, M., Unterman, T.G. (2006) FoxO1 regulates multiple metabolic pathways in the liver: effects on gluconeogenic, glycolytic, and lipogenic gene expression. J. Biol. Chem. 281, 10105-10117. 